

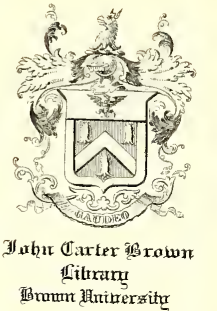

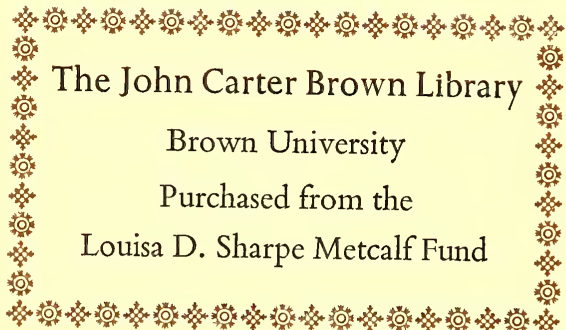


$(1)^{\prime \prime}$

$10^{\circ}$ 


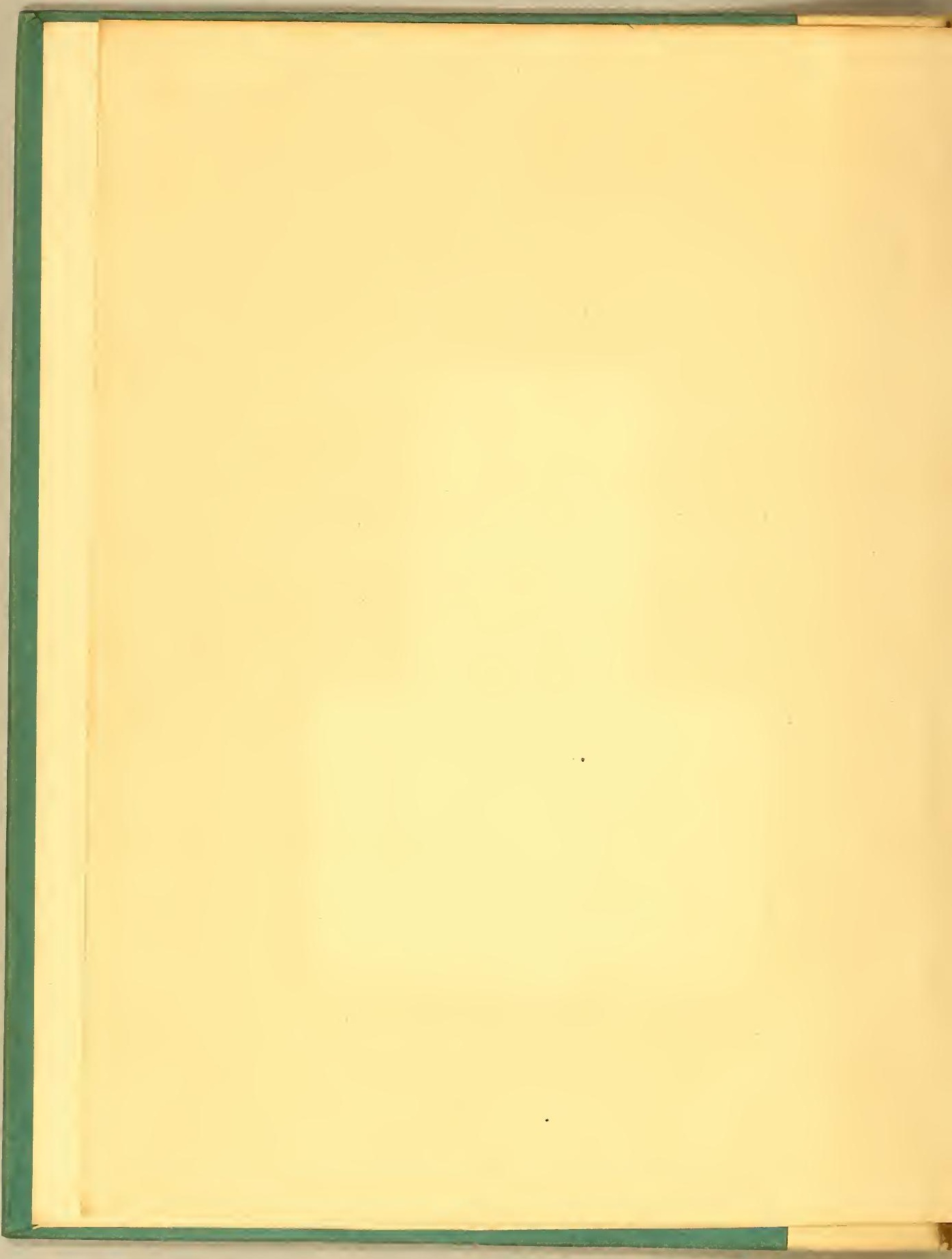




$$
31.8 .910
$$

\section{HEL MEINTHOLOGIA P O R T U G U Z A.}




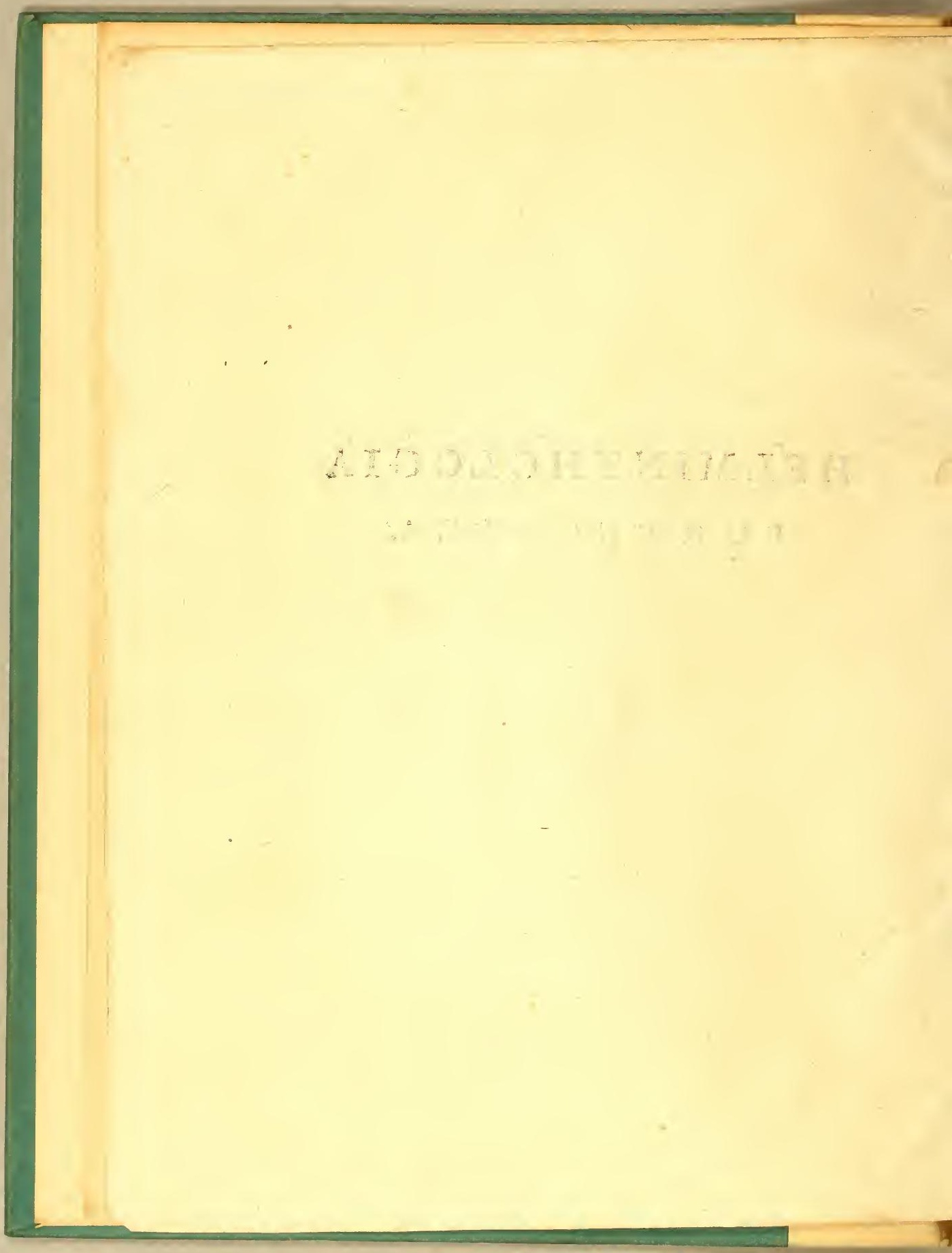






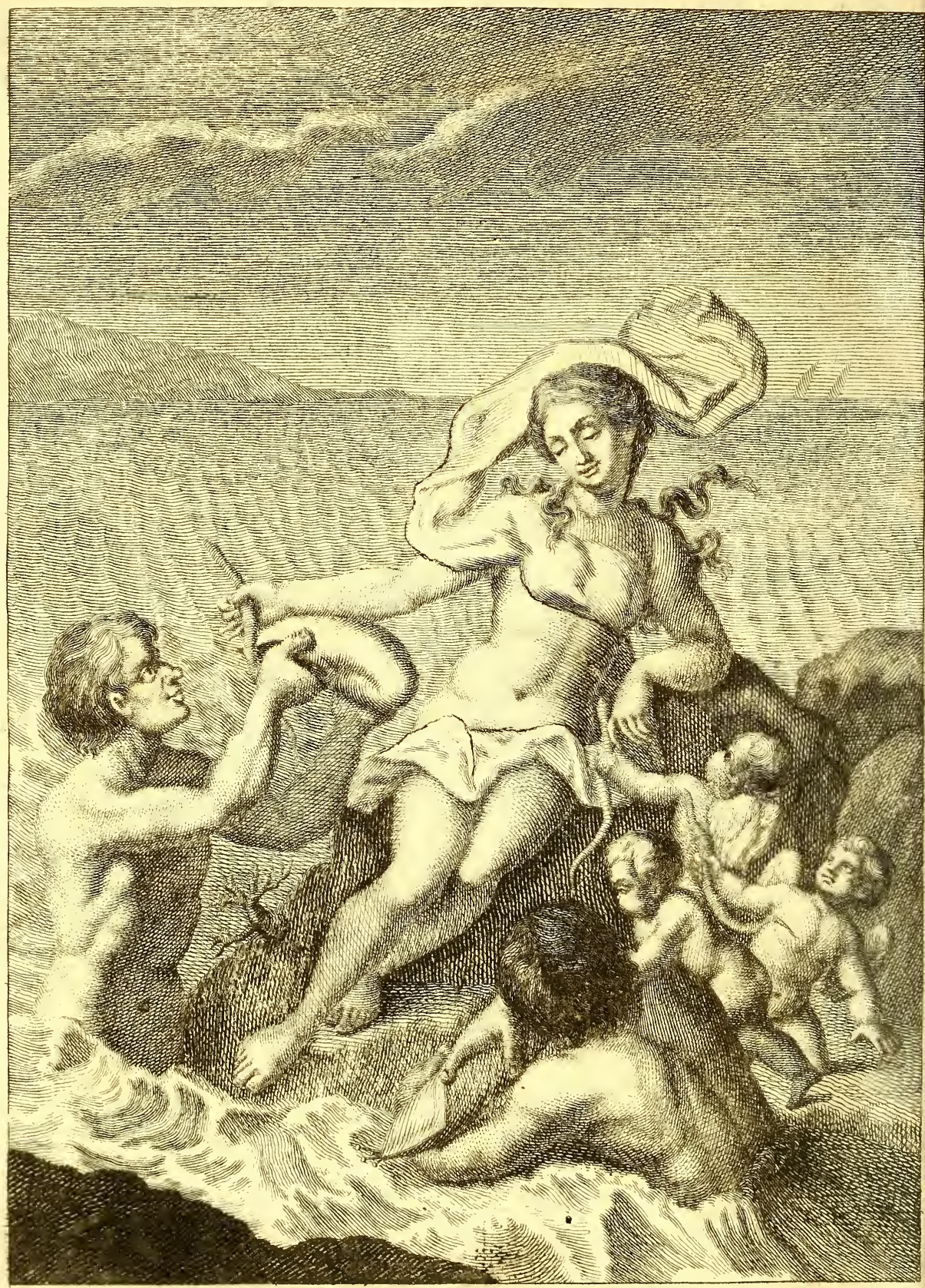

HE. L MINTHOL O GIA PORTUGUEZA. 


\section{HELMINTHOLOGIA}

\section{$P O R$ T U G U E Z A,}

EM QUE SE DESCREVEM ALGUNS GENEROS

DAS DUAS PRIMEIRAS ORDENS,

INTESTINAES, E MOLLUSCOS

D $A$

CLASSE SEXTA DO REINO ANIMAL;

$V \mathrm{E}$ R $\mathrm{M} S$,

E SE EXEMPLIFICAÓ CON VARIAS AMOSTKAS DE SUAS ESPECIES, SEGUNDO O SYSTEMA DO CAVALHEIRO C A R L O L L I N E ;

POR JAQUES BARUT,

$$
\tau R A D U Z I D A
$$

DEBAIXO DOS AUSPICIOS, E ORDEM

DE SUA ALTEZA REAL

O PRINCIPE DO BRASIL

N O S S O S E N H O R,

$$
P \circ R
$$

Fr. JOSE' MARIANO DA CONCEIÇAŎ VELLOSO; Menor Reformado da Provincia do Rio de Ganeiro. Penfonado por Sua Magefade.

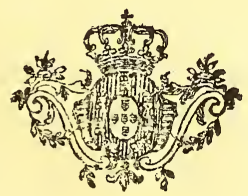

\section{I S B O A,}

Na Officina de JOAÓ PROCOPIO CORREA DA SILVA;

Impreffor da Santa Igreja Patriarcal.

$A N$ N O M. DCC. XCIX, 


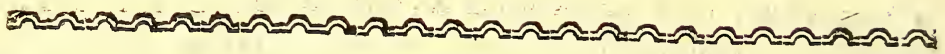

24 Quam magnificata Sunt opera tua, Domine, omnia in Sa. pientia fecifi: impleta eft terra poffeffrone tua.

25 Hoc mare magnum of Spaciosum manibus, illic reptilia; quorum non eft numerus.

26 Animalia pufilla cum magnis. Illic naves pertranfibunt.

Pf. 103,

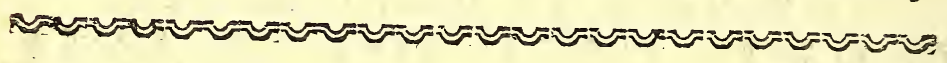




\section{S E N HOR.}

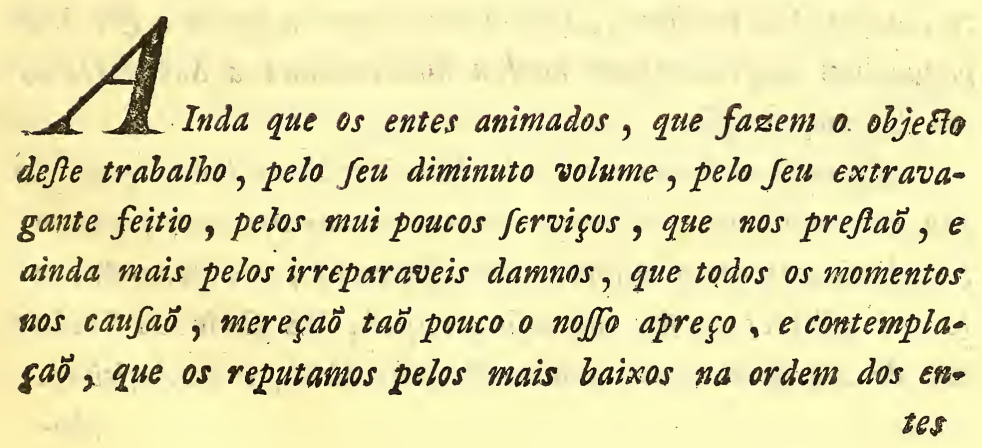


tes animados; e por confequencia, em nada merecedores de terem a honra de ferem aprefentados a $V . A$. R. : com tudo, por efles mejmos principios, faü dignos da contemplaça $\breve{o}$ de qualquer Filnfofo, que o nă for da moderna data.

Por quanto, como animados, gozä́ buma fuperioridade real, o incontefavel jobre os entes dos dous reinos vegetal, e mineral. Elles receberaö do Todo Poderofo hum fopro de vi$d a$, que fenaú concedeo aos inamimados, $e$ aos inorganicos. A Singularidade dos feus orgäos, e do feu mecbanifmo interior, a dos liquidos, aufubiancias aeriformes, que devem circular mas fuas veias, enervos, em que tem o feuconfitutivo, a fua vital animaçắ, enfiă os olbos do Pbyfico mais contemplativo. Defituridos de fangue, de offos, alyuns com elles por fóra do corpo, como os teflaceos, e carecedores de muitos mem. bros, e vifceras, que tem os outros animaes, gozaö de bum modo de exiflencia tắ fimples, taŏ fingular, e taó maravithofo, que tem feito negar a alguns a animaça $\vec{o}$ dos jeus individuos. Onem perfuadira ao povo rude, Serem as Alforrecas, as Aguas más, como chamicó en bumas partes, e em outras higuas vivas, entes animados? Quen dirá que Jaó entes ainda mais nobres, que o unzeiro da manba , e o da noite, e que faŏ melhores, que oouro, que a prata, brc.? $A$ pequenbezs do feut volume realģa infinitamente a sabedoria do jeu Divino Artifice.

Ouando o Sabio, e Santo Rei David os fez dignos da fila contemplaçă, alforto, e extatico nas bcllezas, que eftes diminutos entes animados lbe offereciă̈, naö podendo conter as effusöes do feu maviofo coraçaó, fez Jubir ás Tribu. nas do Alitifimo a alto brado efte patbetico, e anagogico epi- 
phonema. = Senhor, quaö magnificas saö todas as volfas obras! Tudo quanto fizeftes, atè as cousas mais péquenas, Jao inconteftaveis teftemunbos, e documentos do volfo saber: tudo tem o cunbo daquella Sabedoria, com que encbefles o muindo de tă ricas, e maravilbofas coufas. Criaftes bum mar tă vafto, taö efpaçofo, tắ rico, é tắ abaftecido de animaes de rojo, de mifura os grandes com os pequienos, cujo nímero naö tem barreira.

Eu me figuro que $V . A . R$., a vifta defles, que oratenho a bonra de aprefentar nefte volume, pofjuindo o seu $A u$ gufo, e terno coraçaõ, em gráo beroico, as mefmas virtudes, e piedofos fentimentos daquelle antigo Soberano, com as mefmas luzes de Să Filofofia, romperá em expreföos muito analo. gas, e identicas.

Ifo Suppofto, SENHOR, o eftudo defles diminutos animalejos, naö he daquelles, que fó se devem fazer for hum fimples recreio, ou mera efpeculaçă, mas fim por neceffidade.

Por quanto, se o feu util naŏ tem tanta extenfă, que os faga credores de grandes refultados, fempre se lbe encontra algum, que póde muito bem defpertar a nofa senfibilidade, e eftimaģă̈. Quem olbari com apathia para as Sangra. doras Sanguefugas em muitas molefiias, a que faö applicadas, e proprias? Quem ferá infenfivel ao beneficio, que fazem os Gordios, ou Cabellos aquaticos, rompendo a argilla, e guiando a agua pelos meatos intraterraneos, que acabára para o Ourigo comefivel, de que fe alimentavaö os antigos Romanos, e ainda boje os Francezes de Marselha, que os ver. dem como marifcos?

Mas o damnofo dos da primeira ordem, cbamados intef- 
timaes, certamente requer que os efmerilbemos, até onde po: der chegar a noffa penetraçaö. Inimigos disfarçados da nofJa exiftencia vivem comnofco, domicilados em noffas proprias entranbas, divididos em turmas differentifimas, e tantas, quantas faö as diviföes defla Ordem, a faber: Afcarides, Tenias, Lambrigas, Fafciollas, \&c.: naö ceffä̆ de nos atacar infadiofamente, ainda debaixo do rifco, e pena da sua inexiftencia, causandonos inmumeraveis, e irreparaveis males. Saü inimigos inexoraveis da exiftencia animada, que naö perdoaö a Serie algimna de viventes de todas as clafes, de que se fór: ma eflevafífimo, e riquifimo reino. Oufados confpiraö a bum. geral defrogo.

Efes, SENHOR, os motivos, que me moveraó a fa: crificar algumas horas definadas a outras occupacöes, traduzindo em Portuguez, o que efcreveo o Inglez Faime Barbut para eftender o seu conbecimento methodifado, conforme os Canones Linneanos, os quaes me foraö indifivelmiente augmentados pela cerîza, que tenbo (nä̃ fei fe jufta) de nă̈ termos ainda bum só efcrito noffo, icerca da Hifloria Natural defte Reino, e ainda de fuas Colonias, naŏ por falta de peffoas de ta: lentos. Mas o que abfolutimente me acabou de decidir a executar. conz prefteza efte projecio, que concebi, foi a grandeza da protecçaö que $V . A . R_{0}$ concede a efta qualidade de efudos, como por mais de buma vez o tenho experimentado. Ella certamente tom devido a V.A.R. a me ma paixaö que caracte: rifou ass maiores Soberanos da Europa por feus apaixunados, - que obrigon ao Naturalifa Klein a pronoficar grandes avances aos feguíciores defia utilifima Sciencia; viflo que os Soberanos todos faziä delle as fuas delicias = Hiforiz naturalis Scientiam 
tiam in deliciis habent, qui fummam in mundo poteftatem tenent; $=$ porque ainda que ella nes̆ era buna (como elle Sc exprime) Pragmatia polyantropa (trabalbo de muitos bomens) Jegu. ramente era Pragmatia polyatalanta (trabalbo de muito di. nbeiro). Todo o mundo labe, que a Hijforia dos animaes, incumbida a Arifioteles, cuflára immeñas fommas ao grande Alexandre; a do Mexico Sefsenta mil cruzados a Filippe II.; e quanto naö importaria a de Tornefort "a Grande Luis XIV., a de Hebenfrect ao grande Augufto, Rei de Polonia, a de Meferfchmid ao grande Pedro, Imperador das Rufias, a Kamczatkanenje a Augufa Foamoowna?

$V$. A. R., na. precizando defles modellos forafleiros pa. ra os imitar, trilha os paffos de Seu Auguffo Avô , e la Rainba Noffa Senbora, que, tendo já esboçado eftas magnificas obras, referváraó para $V$. A. R. fazer furgir do. Seio dos feus fiéis vafallos, bomens taó benemeritos, como os que acima fora diftinguidos com commiffües tă bonrofas. Alguns já calcaö os terrenos, que V.A.R. lhes deftinou para os seus exames. Fa Seus oibos obfervadores fe achuo difinguindo objectos, que ainda nắ foră efcriptos na tabella dos conbecidos. Elles, se a diffancia os nă privára, ja teria $\breve{o}$ taluez querido voar ao Süpedaneo do Throno, a aprefentalios a V.A.R. Generofanemte deiwáraö os Jeus fogöes domeficos, para Jeguir a voz do feu Supremo Imperante, que os chama para longe, e esfor ça nos perigos, que indifpenfavelmente deveräö enrofar, affim das pontas das Jetas do Antropofago Selvajem, das gurras do Tigre, dos dentes de venenofas cobras, como dos defmanchos da atmojphe$r a$, pelas exbalaģöes apodrentadas dos rios, das lagoas, e pantanos, da aspereza das tecidas, e impenetraveis mattas, que rom. 
perắ, da fragofidade de empinadas Serras, que fubiraŏ. Eu os ementaria, Se foJse capaz de profanar o Sanituario do Tbrono, suppondo o menor efquecimento ein $V . A$. R. , de cuja Sagrada Pefoa digo, o que em outro tempo Virgilio difle do Seu Augufo Deiss nobis, \&xc. Afjim gozará $V . A R$. de bum attributo, fo proprio dos Supremos Imperantes, qual o de criar genios. Queira $\breve{o}$ os Ceos favorecer os dias anuviados do mundo, com as Sem Saborias politicas, fazendo campir no Seu borizonte a bonança, Celeftial Donn, taŏ appetecido!

Entre tanto, affaftado dos perigos, de que contemplo rodeados todos efles benemeritos filbos do meu paiz natal, bem que poljuida da maior inveja, de naó os poder acompanbar nas fuas digrefsöes naturalificas, e excurföes botanicas, fenă com os olbos da alma, fovorecendo $V . A, R$, as minbas tarefas Lit. terarias, birei mulsiplicando, por beneficio da prensa, aquelo las obrus, que a tenuidade dos meus talentos julgar pro. prias para auxiliar eftes novos exploradores da Natureza, para que lhes nä baja de fer precifo recurfos aos Livros forafeiros, que, além de naŏ os haver, fắ de bum preģo exrefivo, os que apparecem.

Em quanto, do Regio Throno defcer benigna luz a altxiliar me, e exiftir cm mim o ja avançado jopro de vida, infiftirei em levar ávante eftes comegos, cedendo a outros o langarem as ultimas linbas cos meus tofcos debuxos. Contimuarei a dar feparadamente os generos, e efpecies de Vermes, que Barbut nă deo neflas duas Ordens : profeguirei com as outras ordens defta claffe, dando os generos da Ordem Teflacea , Zoopbyta, e infuforia, publicados por outras Autbores, e avangando efta tarefa, o mais que me for 
for pofivel, até dar buma volta por todo o reino anima. do, efcolbendo o melbor, que fe ttm Sobre elle efcrito, e eftampado, concluirei tudo com bum Diccionario universal, e difcorrido: do qual os contheudos feră igualmente acompanhados de Eftampas deftramente copiadas. Para tudo conto com a incomenfuravel grandeza da Alma de V.A.R. em cuja presença proftrado offerece efle trabalbo, e toda a sua continusaģă

- mais humilde entre os Fafjallos

Fr. Zosé Mariano da Conceiģắ Velloso. 


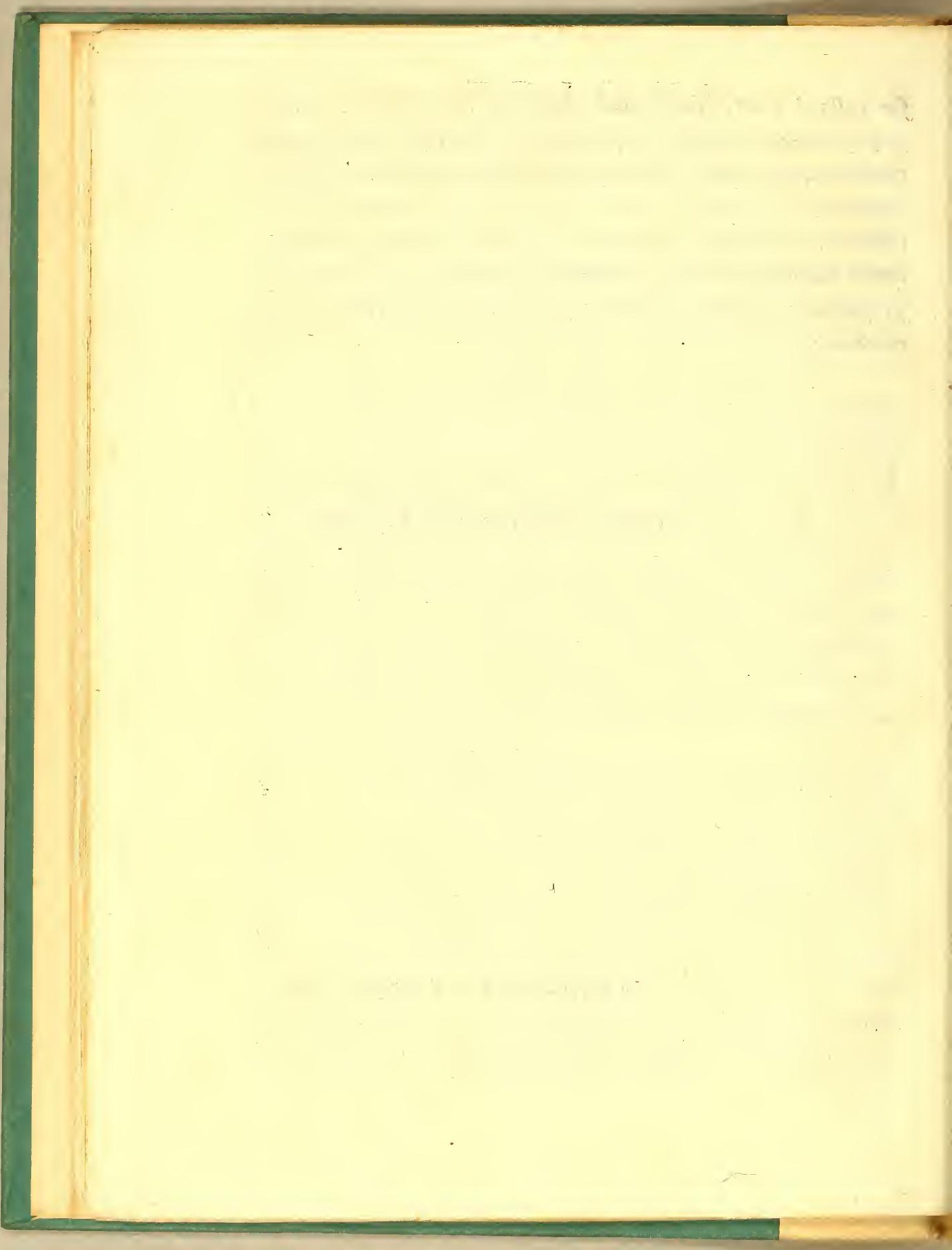




\section{N D I C E}

DOS GENEROS, ESPECIES, E EXPLICAÇAÓ DOS NOMES DAS DUAS PRIMEIRAS ORDENS DE VERMES, INTESTINAES, E MOLLUSCOS:

N. B. Seguio-fe nefte trabalho a XIII. Ediçaó do Syftema Naturce de Linne, Ediçaó de Vienna.

\section{O R D E M I. IN TES TINOS。}

genERo I. Gordio, oll Cabello do maro

$\mathrm{E}_{s}$

- - II. Gordio d'argilla. EAt. I. Fig. 2.

- - III. Gordio mufcular. Eft. I. Fig. 3. ibid.

- IV. Gordio do mar. Eft. I. Fig. 4.

- V. Gordio das alagoas. Eft. I. Fig. 5. ibid.

GENERO II. A SCARIDE.

O nome Afcaride vem da palavra Grega oxcipov faltar, porque eftes animaes faltaó, como os bichos do queijo.

Efp. I. Afcaride vermicular. Ef. I. Fig. $\dot{6}$.

- II. Afcaride minhoca. Eft. I. Fig. 7.

GENERO III. M IN H OCA。

Efp. I. Minhoca da terra. Eft. I. Fig. 8. -

- II. Minhoca do mar. Eft. I. Fig. 9. 9

GENERO IV. FASCIOLA。

Efp. I. Fafciola hepatica. Eft. II. Fig. I.

- II. Fafciola inteftinal. Eft. II. Fig, 2. II 


\section{GENERO V. SYPHAÓSINHO.}

Efp. I. Syphaólinho nû. Ef. II. Fig. $3 \cdot$

- II. Syphaơfinho enfacado. Eft. II. Fig. 4.

\section{GENERO VI. SANGUESUGA.}

Efp. I. Sanguefuga medicinal. Ef. II. Fig. 5 .

- - II. Sanguefuga dos cavallos. ER. II. Fig. 6. ibid.

- - III. Sangnefuga Geometra. Eft. II. Fig. 7. ibid.

- - IV. Sanguefuga ouriçada. Ef. II. Fig. 8.

GENERO VII. MYXINE.

Efp. I. Myxine glutinofa. Eft. II. Fig. 9.

OR DEM II. MoLLúscos.

\section{GENERO I. LESM A.}

Efp. I. Lefma negra. Eft. III. Fig. I.

- II. Lefma ruiva. Eft. III. Fig. 2.

- - III. Lefma grande. Eft. III. Fig. 3.

- IV. Lefma amarella. Eft. III. Fig. 4.

GENERO II. LEBRE Do MAR。

Efp. I. Lebre depiladora. Ef. III. Fig. 5. - II. Lebre maior. Ef. III. Fig. 6.

GENERO III. LIMAó DO MaR。

Efp. I. Limaó enverrugado. Eft. IV. Fig. I. . - Limaó de duas laminas. Eft. IV. Fig. 2.

- Limaó Argus. Eft. IV. Fig. 4. 


\section{GENER O IV. A P Hि ODITA.}

Aphrodita vem de appos efpuma, que, tendo fido o nome de Venus em Grecia, provavelmente o applicou Linne a efte genero, pelo motivo da grande belleza, e do efplendor das cores, que adornaó a alguns dos feus individuos.

Efp. I. Aphrodita de picos. Eft. IV. Fig. 40 28

- - II. Aphrodita efcabrofa. Eft. IV. Fig. $5 . \quad 29$

- - III. Aphrodita efcamofa. EAt. IV. Fig. 6. ibid.

- IV. Aphrodita atelhada. Eft. IV. Fig. 7. ibid.

\section{GENERO V. NEREIDE。}

Impoz-fe-lhe efte nome pela fua pequenhez, e tambem pela fua qualidade phofphorica, e porque eftes animalejos rondaó de noite pelo mar em tanta quantidade, que aclareaô o abyfmo.

Efp. I. Nereide Iuz da noite. Ef. IV. Fig. 8. - II. Nereide das lagoas. Eft. IV. Fig. 90

- III. Nereide barbada. Eft. IV. Fig. 10. ibid.

- IV. Nereide azul. Eft. IV. Fig. I I. 32

- V. Nereide gigantefca. EAt. IV. Fig. 12. ibid.

\section{GENERO VI. Ascidia.}

Vem de asnos odre pequeno, ao qual fe affemelha.

Efp. I. Afcidia mamillar. Ef. V. Fig. I.

- - II. Afcidia gelatinofa. Eft. V. Fig. 2.

- - III. Afcidia inteftinal. Eft. V. Fig. 3.

-. IV. Afcidia campentre. Eft. V. Fig. 4.

GENER O VII. Actinia.

Vem de auros raio; porque todos os animalejos defte genero faó compoftos de tenteadores radiofos.

Efp. I. Actinia velha. Ef, V. Fig. 5 . 
Esfp. VI. Medila de vẻo: Ef. IX. Fig. 6.

- - VII. Medufa parda. Eft. IX. Fig. 7.

- VIII. Medirfa tuberculada. Ef. IX. Fig. 8. ibid.

- IX. Medufa ondeada. Ef. IX. Fig. 9.

- - X. Medufa oval. Eft. IX. Fig. Io.

- XI. Medufa globofa. EAt. IX. Fig. ir.

\section{GENERO XVII. Estrellas do mar.}

Efp. I. Eftrella Lua. Eft. X. Fig. x.

- - II. Ettrella empollada, ou de mamillos. Eft.X. Fig.2.ibid.

- - III. Eftrella purpurea. Eit. X. Fig. 3 .

- - IV. EAtrella reticulada. Eit. X. Fig. 4.

- - V. Eftrella nodofa. EAt. X. Fig. 5 .

- VI. Eftrella aranholla. Eft. X. Fig. 6.

- - VII. EAtrella equeftre. Eft. X. Fig. 7 .

- VIII. Eftrella lifa. Eft. X. Fig. 8.

ibid.

ibid.

ibid.

- - IX. Eftrella Cauda colubrina. Eft. X. Fig.9.

- X. Etrella peftanuda. Eit. X. Fig. Iо.

- - XI. Eftrella em pente. Eft.X. Fig. I X.

ibid.

- - XII. Eftrella cabeça de Medıfa. Eit.X. Fig. I2. 62

\section{GENERO XVIII. OUriço do mar.}

Efp. I. Ouriço comettivel. Et. XI. Fig. I.

- - II. Ouriço das pedras. Eft. XI. Fig. 2.

- - III. Ouriço diadema. Eft. XI. Fig. 3 .

- - IV. Ouriço turbante. Et. XI. Fig. 4.

- - V. Ouriço de mamillos. Eft. XI. Fig. 5 .

- - VI. Ouriço do mar negro. ER. XI. Fig. 6.

6I

- - VII. Ouriço enchada. Eł. XI. Fig. \%。

- - VIII. Ouriço lagoa. EAt. XI. Fig. 8.

- - IX. Ouriço rofa: Eit. XI. Fig. 9.

- - X. Ouriço rede. Eft. XI. Fig. Io.

- XI. Ouriço bolo. EA. XI. Fig. ir.

- XII. Ouriço circular. Eft.XI. Fig. I 2.

ibid.

ibid.

ibid. 


\section{A P O L O G I A}

\section{O A T T O R.}

A Morada de muitos dos animáes, comprehendidos nefta Obra, a diffolubilidade, á que a fua natureza he fujeita ; a abfolita impoffibilidade de fe encontrar algum, que naó feja mutilado, ou corrompido, quando fe tiraó dos feús efcondrijos, diftantes, e profundos, obrigáraổ ao Author a recorrer ao pequeno número de Authores, que efcrevêraó ácerca delles. Comparando os defenhos, que eftes nos deraó, com os proprios animaes, com o conhecimento anterior, que delles tinha, achou que as fuas figuras eftavaó correctas, e que fatisfaziaó a intento. Naố querendo errar nở meio das doces producçóes dàs Sciencias, fem fazer conhécer as flores, de que efpremera o fúcco, do qual compoz efte mel, faz efta pública declaraçaó: Que elle tirára foccorros das Obras de Thomaz Pennant, Efcudeiro; das do Doutor Bohadfch, e do inimitavel Seba. Igualmente fe confeffa obrigado a M. Clancy, Meftre em a Marinha Real, que no tempo, que andou a bordo do Sandwich, diligenciou hum grande número de individuos, a favor do Author. Efta fineza o animou a pedir a muitas outras peffoas, que the podiaó fazer favores, femelhantes affumptos de Hiftoria Natural, e pódem eftar feguros, que fez tudo, o que pode, para chegar ao mais gloriofo de todos os fins, que he a verdade; e por ifto naó fe poupou á trabalhos, nem á cuidados, em todos os exames, que felhe propuzeraó. Naó pode finalmente concluir efte difcurfo, fem confeffar a pro- 
(2)

tecçaổ, que lihe concedêraố algumas Senhoras, e Senhores, que fó pelo fim "de animar a Sciencia, naó duvidáraó contribuir generofamente em dar energia aos debeis talentos do Author. O terceiro, e ultimo volume abrangerá os animaes teftaceos, e como quem quizer, póde ver as amoitras do trabalho, pede o Author o apoio, e encorajamento a todos os Amadores das Sciencias Naturaes.

\section{A D V E R T E N C I A.}

Traductor defia Obra, até o prefente fó tem defe Author efta, contra fobre Infectos. Se entre tanto adquirir a fua continuagaö, de muito boa vontade a communicara ao piśs blico da sua Nacrö, a quem deseja todo o bem. 


\section{P R E F A C I O \\ D O M E S M O.}

$\mathrm{R}$

Eflectindo-fe na fituaçaó dos animaes, que habitaó pelo mar, fenaó deve admirar de naó eftar efta parte da $\mathrm{Na}$ tureza, fufficientemente conhecida. Tem-fe traçado hum grande número de figuras, que aprefentaó as fuas moradías, entre tanto naó conhecemos feus moradores. Donde fe póde inferir, que os noflos Phyficos tem fido mais pintores, que Filofofos, á excepçaó do inimitavel Argenville, cujos conhecimentos, e trabalhos honraó o Seculo, em que nafceo, e o Paiz, em que o víraó nafcer. O immortal Lin. ne arranjon mais judiciofamente os animaes teftaceos, que naó fó ficou fendo o mais analogo genericamente aos mefmos animaes, mas que tambem o ficou fendo em razaó da confervaçaó dos caracteres das fuas cafas, ou moradías, o que fem contradiç̧aó alguma he o methodo mais fcientiffco. E ainda que certas peffoas hạ̣aó tomado a liberdade de criticarem as Obras defte homem raro, e unico, com tudo the ficaráo fendo taó inferiores, affim no brilhantifmo do feu entendimento, como na folidez do feu juizo, como o póde fer hum vagalume, a refpeito de hum refplandecente Aftro.

Os animalejos, comprehendidos commummente na $\mathrm{Or}_{-}$ dem Mollufca, naô feráó talvez taó numerofos, como fe penfa; e efta he a razaó : daó-fe muitos, quue pódem morar 
nas conchas, cujos albergues naó tem nos abyfmos no Oceano: donde, tendo fido lançados por animaes mais poderofos, que elles, ao depois de efcaparem ao inimigo, boiariaó; e a qualidade, que o ar tem de enrijar os corpos, faria que a fua pelle fe voltaffe em couriacea, e adquiriraó huma força fufficiente para nadarem, conforme as diverfas qualidades, que a natureza thes communicaria. Finalmente, a fua apparencia exterior apoia fortemente o meu fentimento, fobre tudo, quando fe reflecte, que os animaes Mollufcos tem muita femelhança na fórma, e caracter gem nerico, aos que fe encerraó dentro das conchas, e que faó fufceptiveis de diminuiçaó, e de grandeza.

Todos os animaes, que fe abrangem debaixo da ordem dos Intefinaes, e dos Mollufcos, faó providos interior mente de muitos mufculos, que lhes communicaó a particular qualidade de fe poderem augmentar, e diminuir a fua vontade. Os diverfos talentos, de que faó dotados, o ajuntamento dos feus tenteadores, feu modo particular de viver, e a maneira porque procuraó o feu fuftento, faó objectos de fatisfaçaó : e ao mefmo tempo obrigaó o coraçaó do homem a refiexóes fublimes ácerca do poder infinito, e fabedoria do Altifimo, que repartio por cada hum dos animaes, o que lhes era mifter, e lhes confignou moradías, muito confórmes ás diverfas funçóes, que elles deveriaó encher. A diverfidade das fuas pertençóes, huns fazendo preza dos outros, os animaes de maior número, fervindo de pafto aos mais de menor, e mais raros, o feu augmento, e diminuiçaó fe proporcionaó aos acafos, a que eftaó fujeitos, 
e affim fe conferva, e mantem a ordem, e o total de todos os generos inteiramente, fem que á efta cadêa phyfica venha a faltar hum fó ello. Talvez que a caufa primitiva do pouco conhecimento, que temos de parte das $\mathbf{O}$ bras de Deos, proceda principalmente da noffa foberba; pois olhamos com defprezo os entes, que a noffa vaidade reprefenta, como aviltados, por ferem de huma natureza taó differente da nolfa ; mas, examinando-os mais de perto, a noffa admiraçaó fe augmentará á medida que a noffa ignorancia fe for diffipando, e o entendimento illuminando ; entaó, pelo impulfo do tranfporte de huma alegria Santa, bradaremos $=$ Oh Deos, quaó admiraveis fañ as voffas obras!

O Verme Gordio, ou Cabello do mar penetra a argilla com a mefma facilidade, com que o peixe corta as aguas. Eftas aberturas daó a ellas huma livre paffagem, para formarem as fontes ; outras defte mefmo genero fe introduzem pelos mufculos, dos que viajaó em ambas as Indias, no entretanto, que outras infeftaó o figado do Harenque, e do Lucio. A Lombriga, ou Afcaride penetra as raizes podres das plantas, e igualmente os inteftinos do homem. A Minhoca fe crava na terra, e nas areias do mar; fornecendo ao pefcador huma excellente ifca para os peixes. A Fafciola fe fuftenta dos bofes das ovelhas, que as engolem muitas vezes, quando mataó a fede nas aguadas, e corregos, e dclla provavelmente procede a ronha, ou gafeira, ou alguma moleftia naố menos funefta á eftes pacificos, e uteis animaes. Quem fabe, fe delles procederá talvez as manchas, que fe obfervaó nos feus bofes. O pequeno Syphaó, ou Syphuncu- 
lo fe aloja, e alberga por baixo dos rochedos, e pela fua boca, do feitio de hum canudo, zoncha, com a agua do mar, os animalejos, de que fe ceva, lançando, como huma feringa, a agua fiperfua. A Sanguefuga, fem embargo de fer fummamente molefta aos peixes, e animaes, a que ellas fe agarraó, todavia fazem hum bem confideravel, quando a Medicina fe vale dellas, e as applica para tirarem o fangue grofo: A Mixine, introduzindo-le no focinho do peize apanhado, que ficou prezo pela ifca de noite, lhe devora to. do o interior, e fó deixa a pelle para o pefcador.

Ora chegamos já á fegunda ordem, a faber: aos Mollufeos, ou Molles, que do mefmo modo recenfearemos. A Lefma, que he a primeira, que fe nos aprefenta, deftroe as raizes, e folhas das plantas, e das arvores, mas a feu turno, ou quando lhe chega a fua vez, ferve de bifcato a muitas aves, como Corvos, Gralhas, \&c. A Lefma, cor de ambar, foi julgada proveitofa nas moleftias do bofe. A Laplyfia, embrulhada na fua capa, fe acha abrigada pelas propriedades, com que a natureza a dotou, affim a refpeito do feu fedor infupportavel, como da dolorofa fentaçaó, que caufa o feu toque. Suftenta-fe das Algas, ou Sargaços, donde fe fegue, que naó obfante quaefquer qualidades venenofas, que eites animaes poffá ter relativamente ao homem, pódem todavia fornecer á outros animaes hum fuftento, naó fómente innocente, mas ainda de muita conveniencia, conforme os factos o fazem ver. Tendo hum Marinheiro apanhado huma Laplyfia, efta lhe caufou dores taô vehementes no mefmo inftante, que logo fe the feguio huma inflammaçaó, 
çaó, e o defgraçàdo homem veio a perder o braço. Eftaô perfuadidos os pefcadores que o humor, que diftilla 0 cor: po deftes animalejos, he hum veneno taó terrivel, que el: les 0 naó querem tocar.

A Doris goza de olhosi, como as Lefmas de terra, and da de rojo entre os rochedos, fuftenta-fe dos Sargaços, daș Coralinas, \&c., e ferve de fuftento , a feu túrno, aọs Caranguejos, ás Etrellas do mar, á Ciba, \&cc. Efte genero concorda com as Lefmas no movimento, e em que os feusianimaes, que o conftituem, quando répoufä́, fe cobrem. vor

O Aphrodita, fingular, pelo frouxel, outpluma avellury tada, de que efte genero fe adórna, anda de rojo pelos rochedos, por meio de leus pés, que fe affemellhaó na figura aos das Lagartas : fuftenta-fe de pequenas conchas, e ferve ao depois de huma faborofa iguaria muitas efpecies marinas.

A Nereide comprehende animaes de differentes grandezas, dos quaes alguns, ainda que imperceptivelnente miudos, fuftentaó-fe de mui pequenos animaes marinosig que fe albergaó entre as duas efcamas dos peixes, e que talvez exiftaô na mucilagem, que refuda dos fens corpos : outros maiores fe apofentá nos ialojamentos tubulófoś dos Tubos do mar, e dos Berbequins ìde cújos moradoreś elles daó cabo: no comenos, que a Nereide gigantefcai, a maiónl defta efpecie, faz buracos nos tanchóes, on mouróes affincados no mar, por onde fura a obra, e a arruina. EAtes animalejos fao mui analogos na fua figura com o:Millepedes, ou Cen-

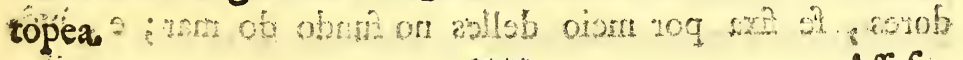




\section{in}

4. Affatamo-nos alguma confa dos animalejos, cujo natural he trabalhar, para contemplar a Afcidia, cujas funçóes faó taó extraordinarias, que diftaó das plantas marinas mui poucos gráos. Sempre agarrada a hum corpo eftranho tem o feu movimento com huma lentidaó imperceptivel, avançando apenas huma pollegada em muitas horas; e por confequencia, nao fe apartando já mais do lugar, em que fe acha no principio, emprega a fua vida inteiramente em attrahir, e expulfar a agua do mar. Entre tanto, que o interior da boca da Afcidia he provida de muitos mamillos mui pequènos, por meio dos quaes, feringando a agua, pára, e retem os animalejos, que lhe fervem de pafto.

- A Actinia fe agarra por huma efpecie de pedunculo nos rochedos, nas Oftras, \&c., e faz huma tal parada, ou vifta de fua cabeça, que mais fe affemelha a huma flor, que a hum ente vivo, e animado. Os raios, de que clla fe adorra, faó os tenteadores, que apanhaó, e conduzem a preza á fua boca, que efta no centro da flor. As vezes tomaó el las fơmas taó varias, que fe julgariaó fer hum genero dif ferente.

A : Thetis mora nos abyfmos do Oceano, agarrando-fe, ou em hum fundo argillofo, ou em os rochedos : vive do Sargaço, ferve de pafto aos Camaróes, e Lagótas, \&c. Efte animalejo he mui pouco conhecido, por caufa da profundeza do abyfmo, em que tem os feus efcondrijos, e moradas; porque poucas vezes feapanha. - A Holothuria, cujo ventre he toda femeado de tenteadores, fe fixa por meio delles no fundo do mar; e mo -2 sith 
venđo ao mefmo tempo os ramos, que ornaó a fưa cạbeça, para procurar o feu fuftento; toma alternativamente figtras en graçadas, e grótefcas, que deraó lnigar aos Phyficos, para lhe imporem nomes, que de fórte alguima faó analogos á fua natureza.

A Terebella ou Berbequim, munida de huma, como broca, fura os rochedos, e obrigada pela natureza a viver na obfcuridade, fica em fegurança, até que o Caranguejo devorador com feus dedos de tenaz a haja de tirar para fóra y e logo devoralla.

O Tritaó, embainhando o feu corpo nas cavidades das rochas, mergulhadas nas aguas, defembainha a fua cabeça, $€$ feus tenteadores de tenaz (Cheliferos), e com eftes apanha tudo, quanto fe the aproxima, e que the póde fervir de preza. Todavia conta muitos inimigos, que tem de combater, como fá as Eftrellas do mar, o Caranguejo, a:Ci$\mathrm{ba}, \& \mathrm{c}$,

A Lernéa fe agarra por detraz dos ouvidos dos pei*es, e femelhante á Sanguefuga, chupando-os, tira todo o fuftento, que necelfita.

A Scylléa, que tem nas coftas o Sargaço, que aboia no mar, por baixo abre os feus tenteadores, ou folhos, para colher o fuftento, que fe lhe offerece no curfo da viagem; mas os Caçóes, e outros peixes fartaó a fua iffaciavel gula.

A eftructura da Clio parece fazella mais propria a fervir de preza, do que a dar-lhe por pafto os outros animaes, -e por efta razaó a proveo de huma bainha em fórma d'embude, ou funil para ande fe recolhe, conforme o requer a necelfidade 
A Ciba, que muitas vezes acontece fer preza do Ro dovalho, e de muitos outros animaes marinhos, frequentemente efcapa , denegrindo agua em torno de $\mathrm{fi}$, por meio de hum liquor, que a Providencia the adminitrou, e de que ella fe aproveita, quando a neceffidade o requer. A fua efpecie naó he meńos voraz, deftruindo outros animaes de menos forças. Encontraó-fe nefte genero de huma grandeza incrivel, eque pela força de feus tenteadores, attrahiriaó hum batel ao fundo d’agua, fenaô a obrigafem a largar a fua preza, cortando-a em póttas com hum machado, inftrur mento, de que fe acompanhaó os Indios, quando andaó nos mares, que faó infeftados por ellas.

A Medufa, que reprefenta fer unicamente huma maffa de gelea fem vida, nadante fobre as aguas do Oceano; traballia com feus tenteadores para apanhar o peixe miudo, que ella devora, Saó animaes gregarios, que andaó em cardumes, e ainda que pertendaó, que ellas excitaó, quandó fe tocaŏ, a mefma fenfaçaố, que as Laplyfras, o Tubaraó *oraz com a vifta raivofa, fe lança fobre ella, e efguelhando-fe, devora hum grande número de huma fó embocadura. Pouco depois da fua morte, a fua fubftancia le desfaz em thnma lympha clara, de forte, que the naó ficaó raftros alguns, de que fejaó animados. Para fe examinar a fua natureza, e propriedades, fe requer confervallas em hum grande vafo de vidro, cheio de aguá do mar, que fe deverá renovar todos os dias. A Actinia, Afcidia, e muitos outros fe poderiäó examinar do mefmo modo, e dariaó conhecimentos extenLos fobre as qualidades deftes entes diverfos. 
Nós entretanto himos ả Eftrella do mar ; que parece polfuir em hum gráo eminente ás funçóes, e ás propriedades da vida animal, bem que o feu movimento feja tardio; e vagarofo, reflectindo-fe no número de feixes, que rodeiáó feus raios, e lhe fervem de pés, para caminharem, para recuarem, e marcharem para todos os lados. Tambem fe ferve defte meio, para fe agarrar com elle aos rochedos, e defender-fe de fer efmagada pela violencia das ondas. Saó tambem outros tantos tenteadores, de que eftes animalejos fe valem, para apanharem as prezas,, e levarem-nas á boca. Os feus raios faó taó frageis, que o menor choque, ou coufa os quebra, mas voltaó a crefcer com o tempo, como acon tece ás pernas do Caranguejo, e Camaróes. Ella fe alimenta dos novos deftes generos, e das pequenas conchas, \& $c_{0}$

O Ouriço he hum animal muito fingular, ainda que feja muito commum: armado de puas, on picos, que lhes fervem de pés, move-fe para todos os lados, - e fegundo quer, ou neceffita, faz fahir os feus tenteadores, com os quaes fe feguraś no fundo do mar, ao repontar os temporaes. Mas a natureza maravilhofamente aformofeou eftes animaes. $O$ mais fabio Efcultor naó poderia efmerar-fe tanto na execu. çaó da fua arte, que podeffe chegar ao ponto de imitar a belleza, a regularidade, o arranjo das fuas multiplicadas ex. crefcencias, que faó as juntas, que fervem de encaixes das fuas puas, ou efpinhos, e das quaes fe valem, para fe moverem por toda a fuperficie calcarea. Humas faó difpoftas', pelo dizer aflim, como em avenidas, ou aléas, on $\mathrm{em}$ can. teiros, outras tecidas em redes, ou encruzadas com a exac- 
çaó mais jufta, e entremeada de excrefcencias miudas de huma fórma globular. Daŏ-fe tambem algumas, cuja coftra, ou cafco he arredondado, ots oval, outras redondas, allongadas, e planas: do mefmo modo que variaó as fuas puas, das quaes humas faó redondas, outras quadrangulares, de oito quinas outras, já em fórma de fedas, ou já de columnas. A cor, quando eftaó esbulhados de todos eftes efpinhos, que cahem, aflim que o animal morre, he magnificamente vária; porque 1e daó verdes, amarellas, arroxadas, pardas, e finalmente, de huma purpura enfraquecida. Tal he a virtude prolifica da Natureza em todas as fuas producçóes, com que ella faz o alarde de huma força prodigiofa em toda a criaçaó, moftrando evidentemente, quanto he infinita a fonte da Sabedoria, de que emanaó as fuas operaçóes. 


\section{A D V E R T E N C I A.}

Traductor defta Obra adverte aos feus Leitores $\mathrm{Na-}$ turatiftas que, defejando ardentemente coadjuvar, aos que fe applicaó aos conhecimentos da Natureza, mediante a Hiftoria Natural, e vendo a raridade, e careftia prefente de $\mathbf{L}$ vros, que os auxiliem nos feus eftudos, fe obriga, havendo a poffibilidade, que prefentemente tem, a dar impreffos, c com figuras, todos os bons Authores, que houverem de cahir em fuas máos. E ainda que elle ame o fyftema do Cavalheiro Linne, ao qual fe cingirá, quanto lihe for polfivel, fem efperar hum tempo, que lhe naó ferá concedido, de o poder dar em huma ordem feguida, o irá dando, conforme poder; e fem fe arrogar a fi a gloria de Author, fe contentará com a de poder concorrer, a que outros o hajaó de fer, ainda facrificando o feu capricho, nefta qualidade de Litteratura. Elle conhece perfeitamente o grande vaó, que ella tem entre os feus compatriotas, e o de que fe neceffita.

Vale. 


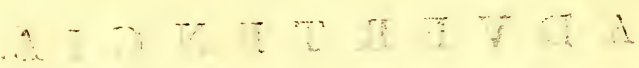

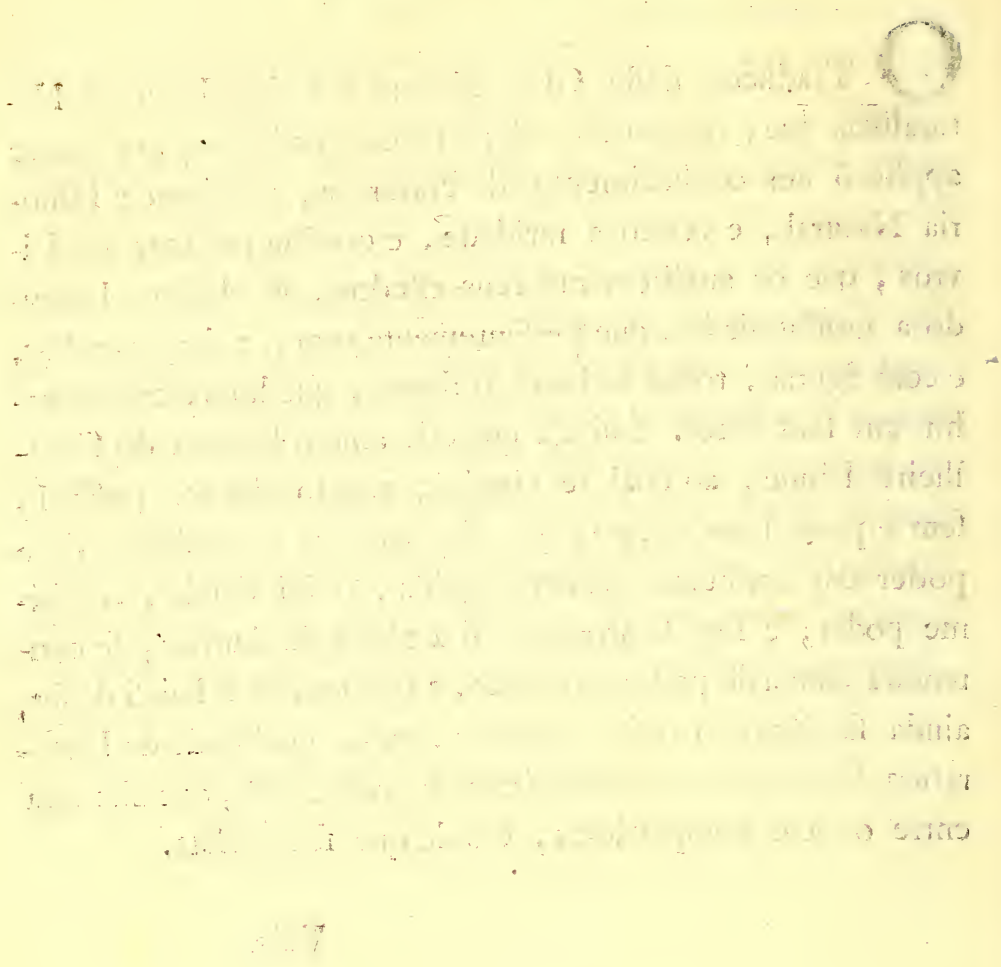

- ...... 
Equivocagöes que teve o Autbor defa Obra, advertidas pe10 Traductor, ao depois de impreffi.

A I. Eframpa a Figura 5., que naó defcreveo no texto, he hum Gordio das alagoas.

Eft. IV. Fig. 2. He outra Doris, ou Limaó do mar, do qual fó dá a figura, e naỏ o defcreve, por onde a 3 . vem a fer a de duas laminas. -

As Fig. I 2. e I 3. faó da Nereide gigantefca, em que tambem fe equivocou.

Ef. VII. As Scylleas 7. e 8, vem a fer a mefma.

Eft. IX. Fig. I2. He a Medufa contrahida, que naó defcreve.

EAt. XI. Fig. I 3. He o Ouriçっ violete, ou Coifa, do Douttor Solander.

A pag. 3. Ee chama a Holothuria Aguama. Eifte nome parece convir á Alforreca, ou Medusa.

Como se ba de continuar efte traballso com buma sesunda Parte, nella fe advertirá ao Leitor de algum outro defcuido, que tiver bavido nefta. 


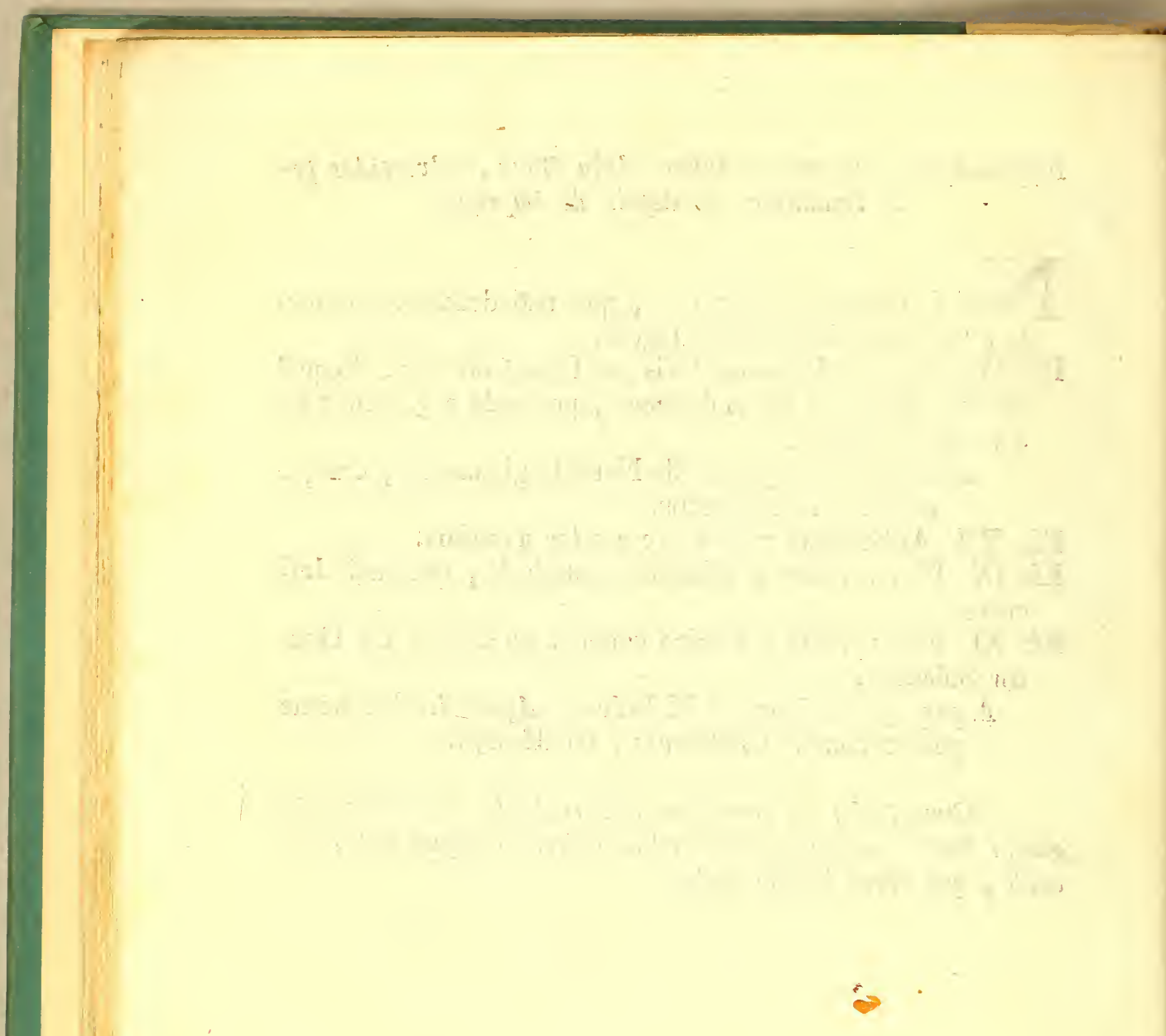




\title{
HELMINTHOLOGIA PORTUGUEZA
}

\author{
o v \\ VERMES DO MAR, E TERRA.
}

$S$ Vermes faó animalejòs de hum movimento progreffivo, e vagarofo; de huma fubftancia molle; capaz de augmentar o feu volume : taó vividouros, que renovaó a fua pelle : faó hermaphroditos, aprazem-fe da humidade : naó tem cabeça, ou pés; e fe conhecem facilmente pelos feus tenteadores.

Os antigos com muita juftiça os chamavaó animaes imperfeitos; porque os viaó fem cabeça, orelhas, narizes, e pés, e pela maior parte fem olhos, e por confequencia abfolutamente diftinctos dos infectos, entre os quaes, e elles, muito tempo ao depois, Linne fezver, que fe naó dava conveniencia alguma fecreta, formada pela natureza. Dividem-fe nas cinco ordens feguintes : Intestinos, Moles, Testaceos, Lythophytos, e Zoophytos.

Os Intestinos chamados antigamente terreftres em virtude da grande fimplicidade da fua eftructura penetraó, ou furaó tudo. $\mathrm{O}$ GRoDio fura a argilla para haver de dar paffagem ás aguas. A Minhoca fura a terra para que efta fenaó corrompa pela inacçaó. A Mrxine fura os corpos mortos para aligeirar a fua corrupçaó.

Os Molluscos; on Molles faón nûs, providos de braços, habitadores do mar pela maior parte, poitos ao ar luzem, e fendo naturalmente phofphoricos, ou luminofos daó tanta luz no abyfmo tenebrofo, como dariaó os lampióes, de maneira, que as partes, que lhe ficaó por baixo, fe affemelhaó á abobada azulada, que anda fuperior ás noffas cabeças. 


\section{CARACTERES DOS GENEROS.}

$$
\text { I. INTESTINOS. }
$$

Animaes mis, desprovidos, de membros.

$$
\text { * Furados com bum poro no lado. }
$$

x. 1 inhoca. O corpo delgado com hum annel carnudo, que lhe cinge a cintura.

2. Verme tubuloso; com o corpo adelgaçado, e hum bico, ou beque cylindrico, e encolhido, fahindo do cor po pouco a pouco.

3. Fasciola : com o corpo applainado, e tendo hum poro no ventre.

*** Naö furados. Saŏ os que naö tem poro algum no lado.

I. Gordio, ou Cabello aquatico. Todo o corpo filiforme.

2. Ascaride, on Lombriga vermicular. O corpo afilado, ou affovelado nas duas extremidades.

3. Sanguesuga. O corpo ponco afilado, e troncado ero ambas as extremidades.

4. Mixine. O corpo aflado, a boca abroquelada, e com queixos grandes. 
II. Molluscos, ou Molles.

a Com a boca por baixo, fixando Se com ella em buma base.

1. Actrnis. Huma fó abertura commum, e capaz de fe alargar.

2. Ascidia. Duas aberturas, das quaes huma he mais baixa, que a outra.

b Com a boca por diante, e o corpo furado em bum dos lados.

3. Lesma. Quatro tenteadores; e o anus commum com hum poro no lado.

4. Laplysia. Quatro tenteadores; e o anus por cima das partes pofteriores.

5. Doris. Dous tenteadores; e o anus em cima das partes pofteriores.

6 TheTrs. Dous buracos no lado efquerdo.

c Com a boca por diante, o corpo rodeado de tenteadores por diante.

7. Aguama, ou Holothuria. Tenteadores carnudos.

8. Broca. Tenteadores capillares. 


$$
\text { *. HeLM I N THOLOG a }
$$

d Com a boca avangada, o corpo provido de bragos.

9. Tritad. Buçss divididos em dous, e alguns deftes cheliferos. (I)

ro. Cria, ou Lula. Oito, ou dez braços fornecidos d'articulaçóes.

I I. Curo. Dours braços eftendidos.

I2. Lernea. Dous, ou tres braços adelgaçados.

13. Scyllea. Seis braços, cujos pares faó affaftados huns dos outros.

e Com a bocapor diante, è corpo fornecido de pés.

14. Aphrodita. A boca fem arma, o corpo oval.

15. Nereis, ou Nereide. A boca armada de unhas, corpo allongado.

\section{f Com a boca por baixo no centro.}

I6. Miedusa. O corpo gelatinofo, lifo.

17. Estrella. Corpo couriaceo, armado de pontas.

38. Ouriço do mar. Corpo coftrado ${ }_{2}$ armado d'efpinhas.

(I) Dedos; como ténaz, com dentes. 


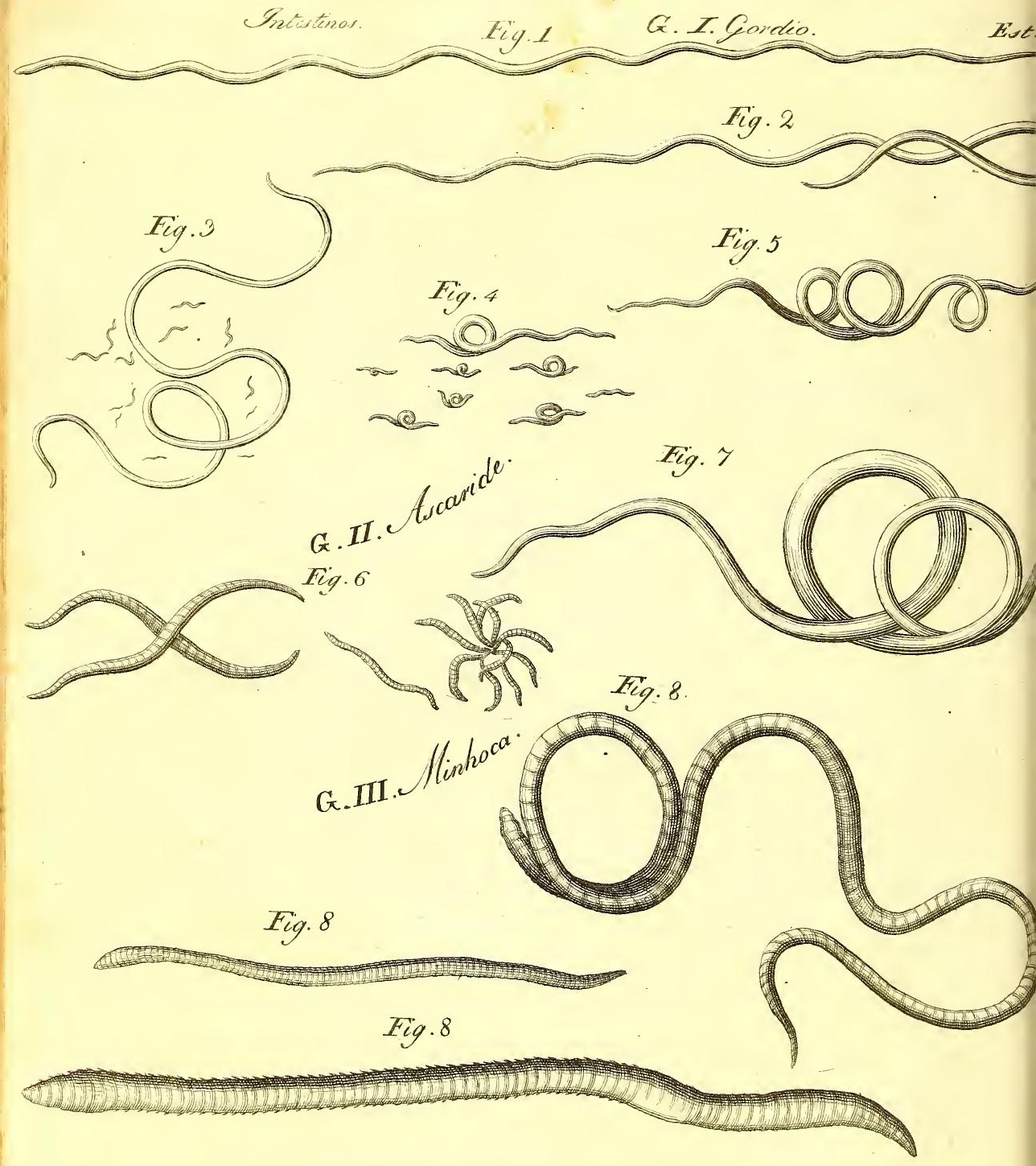

$$
\text { Fig.9 }
$$

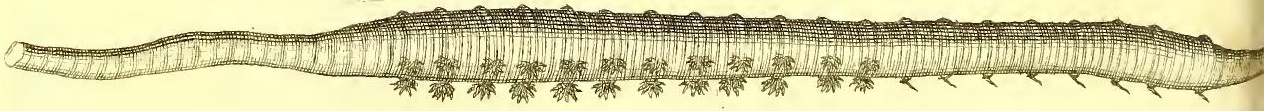




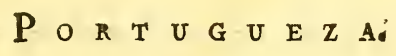

\section{O R D E M P R I M E I $R$ A:}

$$
\begin{array}{llllllllll}
I & N & T & E & S & T & I & N & O & S .
\end{array}
$$

Caracter generico.

Animaes simples, niis, Jem membros

$$
\text { G E N E R O I. }
$$

Gordo, ou Cabello do mar.

Carąter generico.

Corpo, como bum fio, roliģo, e lijo:

\section{Gordio, ou CAbello aquatico. Ef. I. Fig. I.}

Ste animal em toda fua extençaó tem dez, ou doze pollegadas de comprimento, e algumas vezes mais. A fua groffura he igual á de hum cabello. A pelle he lifa, e algum tanto lufidia ; mas fem arregoamento algum. A côr he amarella pallida, tirante a branca por toda a parte, menos na cabeça, e cauda, que faó negras, e lufentes. O corpo he arredondado, e mui franzino, ou delgado, em razaố da fua longitude. A boca he pequena, fituada horifontalmente. Os queixos fáo ambos de igual comprimento, e obtufos na fua extremidade. Encontra-fe muitas vezes nas aguas doces, e com particularidade nas argillas, pelas quaes paffa, como o peixe pela agua, e por iffo dá occafiaó á abertura de muitas fontes.

Efte he oVerme, que em Guiné, e nos Paizes quentes fe introduz pela carne dos moradores do Paiz, e far 


\section{6 I E L I N THOLOGIA}

grandes eftragos. Ora ainda, que fejaó muito communs no nollo Paiz (Inglaterra), já mais fizeraó deftes attentados.

\section{Gordio d' argilla. Ef.I. Fig. 2.}

Sómente he huma variedade pela côr amarella nas fuas extremidades. Efta efpecie habita principalmente n'argilla, a qual Linne chama o feu proprio elemento; porque de ordinario nelle he, que fe encontra.

\section{Gordio mufcular. Ef. I. Fig. 3.}

He o fer todo de huma cor amarella pallida. Vemnos das duas Indias, onde fe encontraó muitas vezes no orvalho da manhã, e donde fe paffa para os pés defcalços dos efcravos, e caufa huma moleftia muito conhecida naquelle Paiz, e á qual as crianças faó muito fujeitas. Caufa coceiras incommodas, e muitas vezes inflammaçaó, e febre. Os mufculos dos braços, e das pernas faó as partes, que elles priricipalmente infêtaó; e donde fe tiraó, ou com hum pedaço de feda, ou com hum fio prezo á cabeça; acautellando-fe com tudo, ainda fendo taó fimples efta operaçaó, que fe naó quebre algıma parte do animalejo pela muita furça; porque, fe acontecer ifto, furará alguma parte entre a pelle, e o corpo, fe reproduzirá de novo com dobrado vigor, e ferá hum inimigo cruel, algumas vezes fatal, aos pobres efcravos em particular. Os banhos com infusóes de plantas amargofas, e todos os vermifugos deftrocm elte VERME. 
IV. Gordio do mar. Ef. I. Fig. 4.

Efte animal, filiforme, e torcido em caracol, e applainado, de quafi meia pollegada de longo, de côr esbranquiçada, lifo, e quafi fem diminuiçaó na cabeça, naó arormenta menos aos Harenques, aos Muges, e a outros peixes, do que o muscular naó incommoda ao homem. Os peixes infeitados por elles fobreaguaó no mar, e rolláó, como fe foffreflem dores mortaes.

\section{G E N E R O II. \\ LOM B R I G A (Afcaris)}

Caracter generico.

Corpo roligo, filiforme, e adeigaģado nas duas extermidades:

I. Lombriga, ou Ascaride vermicular. Ef. I. Fig. 6.

Ste Verme tem quafi huma pollegada de longo , e a groflura de hum barbante : he de huma côr ruiva pallida, com a fuperficie igual. Tem a cabeça pequena, e aguçada, e a cauda pont'aguda. A fua eftructura delicada o facilita a fer efmigalhado. Encontra-fe no lodo em o fundo dos rios, e algumas vezes na terra pela primavera, mas acaba antes do eftio. Inferta o inteftino recto das crianças, e dos cavallos, e de noite muito mais os incommôda, e, quando fe expelle fora, move-fe. O remedio mais efficaz faó fuppofitorios feitos de fubftancias amargas.

Em qualquer parte, em que fe encontraó fẹ, achaô juns- 
juntos em molhos, unidos, e entrelaçados huns com os outros.

\section{Lombriga minboca. Ef. I. Fig. 7 .}

Efta fegunda efpecie tem o comprimento da minhoca; mas, faltando-lhe o annel elevado, fica totalmente differente. $\mathrm{O}$ feu corpo he adelgaçado, de côr branca da nata, terminado em fovella, em ambas as eftremidades. A canda he triangular, e de ordinario tem nove pollegadas de comprido, e muitas vezes excede. He viviparo, e prolifico: mora nos inteftinos da efpecie humana, cujas crianças muitas vezes deftroe.

\section{G E N E R O III. \\ M I н о с А (Lumbricus.) \\ Caracter Generico.}

Corpo roliço, rodeado de buma cintura levantada, efcabroso pelo Seu comprimento, e provido de bum poro lateral.

\section{Minhoca-da terra. Efl. I. Fig. 8.}

A

Mrnhoca he hum Verme, que anda de rojo, e que o Homem o piza com os pés, e olha para elle com defprefo; mas fem embargo diffo, aflim como os outros entes animados, goza da vida, do movimento, da fenfaçaó, e de todas as faculdades animaes.

A defigualdade do feu corpo, armado de differentes pellos enrugados, e pontagudos the dá huma grande facilidade 
dade para a fua márcha colleada. Quando fe quér metter pé la terra, the fahe do corpo hum liquor vifcofo, mediante o qual, elle fe infinua. Ceva-fe em huma mediocre porçaó de terra, que tem o poder de a digerir, e da qual lança fóra o fuperfluo, á maneira de hum excreto, com a apparencia de Vermes. Efte innocente reptil nunca offende as raizes dos vegetaes. He hermaphrodita, e tem as fuas partes fexuaes junto ao pefcoço. A fua copula fe faz em cima da terra, da qual fe ve á fuperficie crivada de buracos, que elle pratica, quando fahe a procurar as fuas femeas.

No acto do feu ajuntamento lhe ferá mais facil deixar-fe efmigalhar, do que defunir-fe. Sómente fahe do interior da terra, quando tem precedido grandes chuvas, ou quando o tempo ameaça tempeftades, ou na eftaçaó dos feus coítos.

Para o obrigar a fahir, feria precifo regar-fe a terra com infusổes de hervas amargofas, on calcalla com os pés. Unicamente bafta o movimento na fuperície da terra, para o fazer fobir, pelo medo, que tem de fer furprendido pelas toupeiras, fuas formidaveis inimigas. $O$ gofto varia fingularmente em cada huma das naçốes : as minhocas faó appetecidas pelos Indios, como hum manjar faborofo.

Ellas fe differençá affaz na fua côr, e na apparencia exterior, conforme os vários periodos da fua exiftencia; e por efte motivo muitas peffoas, mas mui pouco verfadas nas mudanças deftes animalejos, fizeraó dellas quatro, oı cinco efpecies differentes. A fua côr ordinaria he avermelhada lavada.

\section{M I н о С A do mar. Eft. I. Fig 9.}

He de hum vermelho pallido, compofta de muitas junetas annullares. A fua pelle he efcabrofa, e todos os anneis, ou juncturas faó cobertos de pecunenas elevaçóes, que as fazem excefivamente groffeiras ao tacto. Fabricaố a fua ca: 


\section{to \\ HEIMINTHOEO G I A}

fa na aréa fobre as praias do mar, onde fervem de pafto a muitos peixes. Perto de Boyor, no paiz de Suffen, pelos roshedos fe encontraó de huma grandeza extraordina. ria, e fervem aos pafcadores de ifca, para cevarem os feus anzoss, e redes.

\section{G E N E R O IV.}

F A S C I O L A.

Caracter Generico.

O corpo chato: com bum poro na extremidade, e no ventre.

\section{Fasciol a bepatica. Eft. II. Fig. r.}

Ste animalejo chega ao comprimento de dous terços de huma pollegada, ainda que ordinariamente fe ache menos d'ametade. A fua largura quafi igualla os dois terços do feu comprimento. Bem que feja chato, temalguma redondeza nas coftas, e quafi oito regos profundos pelo comprimento em duas feries. A pelle he macia, embranquecida, e com huma fombra parda. A parte poficrior arredondada, a anterior provida de huma grande boca. Parece fe algum tanto com a femente de cabaço ordinario. Encontrafe nas aguas doces, nas vallas, por baixo das pedras, e algumas vezes nos inteftinos, e outras na fubftancia das vifceras dos quadrupedes. Efte animalejo differe da Tenia em naó ter articulaçóes.

Algumas vezes infefta ofigado das ovelhas. Ifto fe remedeia com facos cheios de fal dentro dos curraes, para que os carneiros os lambaó. 


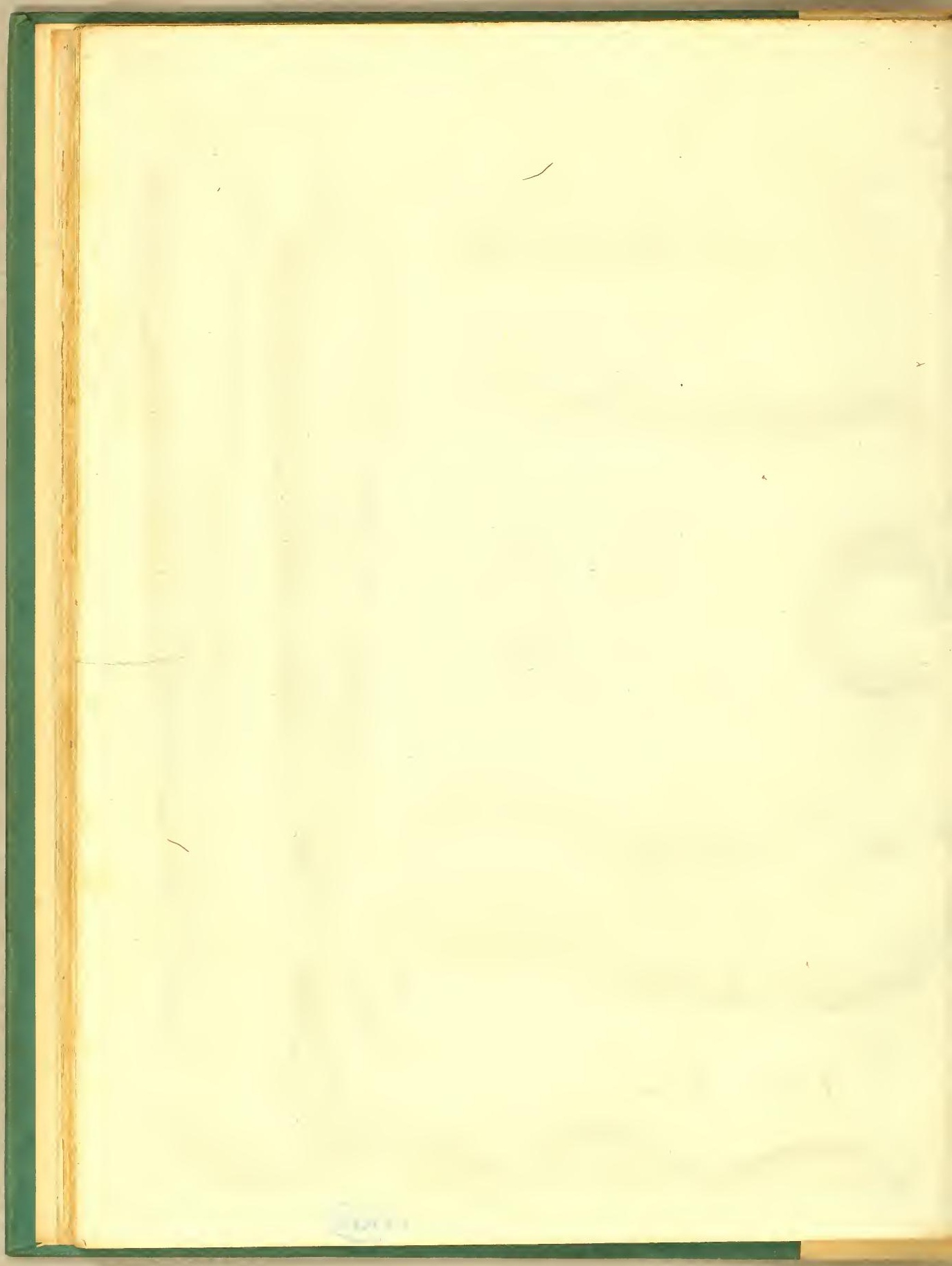




\section{F A S c r o L a inteftinal. Ef. II. Fig. 2.}

Quando fe eftende he delgada, e comprida : quando fe encolhe, quafi oval. Mora nos intentinos dos peixes d'agua doce, efpecialmente nos fargos.

\section{GE N E R O V.}

SIP HA ÖSINHO。

Caracter Generico.

Corpo roliģo, e comprido, com a boca dianteir a adelgaçada, lindrica, e o poro literal enverrugado.

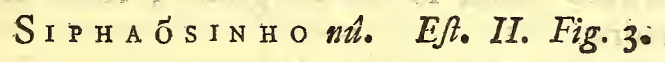

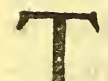

Lm mais de oito pollegadas de comprido, e def de a cabeça até á cauda a fua figura he femelhante a hum cartucho, ou a huma pyramide conica. Tem nove linhas de diametro em a bafe, e quatro na ponta. A parte do corpo mais larga he a cabeça, on a bafe, provida de huma boca com huma tromba acanalada, ou Siphaổ de huma membrana forte, guarnecida de mamillos carnudos com tres pontas, da groffura de hum graó de milho. Elta tromba eftá totalmente pegada a borda da boca, e a outra defpegada : eftende pelo comprimento de huma pollegada, e fe encolhe conforme o animalejo quer. Penfo que, quando elle a eftende, he para apanhar, o que deve comer, e trazello á boca. Entre tanto que a eftende, os mamillos eftaó fóra, mas dentro da bo$\mathrm{ca}$, quando efta encolhida, donde fe fegue, que ofultento, apanhado pela parte livre da tromba, naó lhe póde efca$\mathrm{B}$ ii 
par; e ainda quanto mais a recolhe para dentro, tanto melhor o tem feguro, porque os mamillos the fervem, como de pequenos dentes, que o retem. Tem em diftancia de pollegada e meia da boca huma abertura allongada, rodeada de hum beiço, que fobrelahe, potta a travez. Naó he facil conhecer fe eftá pofta nas coftas, ou na barriga, tendo todo o corpo delte animalejo a mefma uniformidade.

Todo o feu corpo he branco, côr de barro, ornado de eftrias profundas, humas longitudinaes, e outras circulares. As longitudinaes tem o comprimento de meia linha; as circulares de linhas inteiras humas das outras a travez das. quaes fe vê a pelle em fórma de quadrados oblongos, figurando toda a fuperficie do corpo como huma rede.

Parece com a hydra no feu movimento; porque humas vezes fe allonga a hum pé, outras fe encolhe, alargando a parte eftreita do feu corpo para a ponta, que he efpherica. Finalmente nunca fe faz em globo, como tenho vifto fazer a hydra.

Habita no mar alto, donde nunca he lançado ás praias, mas cahe ás vezes com os peixes nas redes, e naồ ferve em parte alguma de fuftento, nem os pefadores lhe tem defcoberto ufo algum.

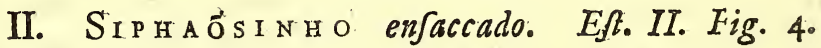

Tem a figura do precedente, com huma pelle alguma coufa frouxa, membranofa, e diaphana, em a qual parece eftar mettida, como em hum facco. A fua moradia he no. Occeano Indico. 


\section{G E N E R O VI.}

S A N GUESU G A.

Caracter Generico.

Corpo allongado, que se move, ou adianta por meio da cabeģa, da cauda, que se dilataó em forma de circulo.

I. Sanguesuga medicinal. Ef. II. Fig. 5.

C

Hega ao comprimento de duas ou tres pollegadas. $\mathbf{O}$ corpo he pardo, tirante a negro, affignalado nas coftas de feis malhas amarellas, bordadas por cada lado de huma linha da mefma côr; mas affim as manchas, como as linhas defcahem de côr, e defapparecem inteiramente em certas eftaçóes. A cabeça he menor, que a cauda, que fe apega a tudo, que o animalejo quer, com muita firmeza. He vivipara, e de cada vez fó produz hum filho, e no mez de Julho. A fua moradia he n'agua, e he a melhor fangradora, efpecialmente nas hemorroidas.

\section{SANGUESUGA dos cavallos. Eft. II. Fig. 6 .}

Efta efpecie he mais groffa, que a precedente. Tem a pelle lifa, e luftrofa , e o corpo comprido, de huma côr efcura as coftas côr de cinza, a barriga de hum verde amarellado, tendo em hum dos lados huma borda amarella. Mora nas aguas fedicas, ou eftagnadas.

III. Sanguesuga Geometra. Ef. II. Fig. 7 .

Tem pollegada e meia de grandeza; a pelle lifa, e luftrofa, de hum pardo acinzentado; em certas occafioes, 
porém de hum verde, manchado de branco. Quando fe move, as coftas $f e$ lhe levantao , o que a faz femelhante a hum compario no afto de fe medir com elle : o que the deu o nome. A fua cauda tem huma largura notavel, e fe ferve della, para fe fegurar com a mefma firmeza, com que fe ferve da cabeça.

Encontraó-1e pelas pedras nas aguas correntes de pouca profundeza, e muitas vezes em cima das Trutas, e de outros peixes, ao depois de terem efres defovado.

\section{SAngue U a ouriģada. Ef.II. Fig.8.}

Tem o corpo adelgaçado, ou afilado, arredondado em a grande extremidade, e provido de dois pequenos tenteadores, ou pequenas pontas, de muitos anneis, e eftes efcabrofos. A cauda inchada: apega-fe aos peixes, e deixa nefte lugar de ordinario hum fignal negro.

Encontra-fe no Occeano Atlantico, e os pefcadores a denominaó Sanguefuga do mar.

Efta efpecic tem os orgãos da geraçaó formados da mefma maneira que as lefmas, que vivem em terra, e no mar. A fua cabeça he provida de hum inftrumento aģıdo, que de cada rez faz tres feridas. Saó tres protuberancias agudas, dotadas da rijeza neceffaria, para penetrar qualquer homem, ou animal, feja efte boi , ou cavallo. A boca tem o corpo de huma bomba ; e a fua lingua, on mamillo carnudo faz ás vezes de hum piftá, cujo movimento zoncha o fangue pelo canal, que o conduz ao eftomago do animalejo , o qual he huma pelle membranofa, dividida em vinte e quatro cellulas. O fangue, que fe extrahe, fe conferva nelle, quafi fem coalhar por muitos mezes, como provifao do animalejo. As fuas partes nutritivas, eftando puras, e já digeridas pelos animalejos, fómente requerem fer defpegadas das fubftancias heterogeneas. Defta maneira fería difícultofo defcobrir-fe o anus da Sanguesuga, quando 
do parece que fómente fe vê, que ella tranfpira; porque a mareria, apegando.fe á fuperficie do feu corpo, fe defpe$\mathrm{ga}$ ao depois delle $\mathrm{cm}$ miudos fios. Difo fe podem certificar, mettendo huma Sanguefuga $\mathrm{em}$ azeite, no qual vivirá por muitos dias. Tírando-fe defte, e pondo-fe n'agua, parecerá, que defpega de feu corpo huma efpecie de excreto da fórma do corpo do animal. O feu orgaó da refpiraçaó, bem que até agora fenaó tenha determinado, parece cftar pofto na boca; porque, fe ellas, do mefmo modo que os infectos, refpirâfem pelos lados, naó poderiaó certamente exiftir no azeite pela razaó, de que efte os teria fechados. Póde muito bem fer que as Sanguefugas forem as primeiras, que enfinafem aos homens a fangria. Quando fe tem os pés mettidos n'agua, ellas fe apegaó a elles, e o fangue, fem fe perceber, corre pelos lugares, que ellas picaŏ. Para remedio fe efcolhem as melhores efpecies, que faó as que fe encontraó em aguas correntes. Applicaô. $f$ e aos vafos nas partes tenras, para que tirem dellas o fangue groffo, de que elles ahundaó, ou para fangrar os meninos. Naó fe pegando as Sanguefugas, fe poem huma gotta de leite, onde ellas fe hao de fixar, ou por hum ligeiro corte fe lhe tira algum fangue, e depois difto logo fe pegaó. Servindo-fe porém dellas para as hemorroidas, pede a prudencia o tellas: ohrigadas a hum pedaço de junco, pelo medo de que ellas fe naó introdufá to anus; e tambem para que naó paffem ao efofhago, quando fe applicaó a tirar o fangue das gengires. A naó fe ter efta cautella, faria hum grande prejuizo, afim no eftomago, como nos inteftinos. Mas no cafo, de que ifro aconteça, o melhor remedio fería beber agua falgada, de cujo meio ufaó, para que ellas larguem, o que chupaó á muito tempo. O oleo de tartaro, o alkali volatil, a pimenta, e os acidos as obrigaó a largar a parte, a que ellas fe apegaó. Ao contrario, querendc.fe que ellas tirem mais fangue, fe thes corta a extre. midade da cauda. Entaó incanfavelmente cl ipaó, rara repa. rar a gerda. A effufá de fangue, que fe faz, cm confequencia da

mor - 


\section{6

mordedura de huma Sanguefuga, fe para facilmente com agna ardente, ou com algum outro eftiptico. $\mathrm{Na}$ Ilha de Ceilaó, os que caminhaó defcalços, fe incommodaó pelo grande numero de Sanguefugas, que fe efcondem debaixo. das plantas. Todas ellas mudaó de côr, fegundo as eftaçốes; mas faó de hum pardo verdoengo tirante a amarello, e muitas vezes extravagante. Dizem que ellas, mudando-fe o tempo, quando fe tem encerradas em vidros, fe inquietaó, o que me parece, proceder mais da fua prizaó, do que de terem alguma difpofiçaó de predizerem.

\section{G E N E R O VII.}

\section{$M Y X I \times E$.}

\section{Caracter Generico.}

Corpo roliço, aquilbado por baixo, com buma barbatana gorda. $A$ boca terminal, e com barbas. Dous queixos combarba. tanas, $e$ a boca com muitos dentes agudos. $O$ dente superior agudo, e unico: sem olbos.

\section{M ч $\times$ I N E glutinoSa. Ef. II. Fig. 9.}

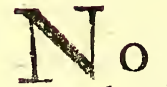

caracter generico defte animalejo fe tem commettido hum erro manifefto; porque a Myxine tem dous olhos, que faó fummamente pequenos, e a dizer-fe a verdade, apenas viziveis, o que obrigou a Villugby, e a Ray a chamallo Lampreia fem olhos, e fegundo o meu parecer, fem faltar ao refpeito, que devo ao juizo fuperior, de Linne, deveria fer arranjado na ordem dos peixes; e parece que o melmo labio fó fizera delle huma efpecie feparada, e diftincta, em razaó da fua natureza, e proprieda- 
des, raó fazendo conta da analogia, que tem com as Lampreias pela fórma, e caracter.

Ef̂te animalejo naó excede no feu ccmprimento a oito pollegadas, fendo o feu corpo proporcionadamente affillado. A cabeça pequena, arredondada, obtufa; os olhos taó pequenos, que apenas fe percebem: a boca he muito pequena, e formada em redondo, como a de huma bolfa, fituada debaixo da cabeça. Naó fe the diftinguem narizes; o corpo affilladifimo, e redondo; mas naó igual, e lifo como na efpecie Lampreia; porque he annular, como o dos infectos, menos em naó ferem feus anneis taó profundos. As coftas faó de cor de azeitona pallida, com hum matiz amarello pelos lados, e o ventre branco argentado. $\mathbf{O}$ que com tudo diftingue efte animal da Lampreia, faó os dous appendices, ou achegas, que tem em torno da boca. Mora no Oceano Europeo entre os peixes, que the fervem de pafto: e M. Linne affirma, gue elle tem a virtude de mudar a agua em colla fórte. Sufpeito que elle diffe ifto fem outra certeza mais, que apoie efte facto, fenaó bum ouvi dizer, naó tendo tido, em quanto a mim, conhecimento da tal qualidade da Myxine. 
2.8 HELMINTHOLG A

\section{O R D E S E G U D A. \\ $M \circ I, L$ U S C O S.}

Caracter Generico.

Animal famples, $m \hat{\imath}$, Jem concha, mas fornecido de membros.

\section{$\mathrm{F}$}

Sta Ordem comprehende os feguintes generos. I. LESMa. 2. Lebre marina. 3. Limaó marino. 4. Aphrodita. 5. Nereide. 6. Ascidia. 7. Actinta. 8. Thetis. 9. Holothuria. Io. Terebelea, ou Fura pedras. il. Tritáo. 22. Lernea. 13. Screlea. 14. Clio. 15. Grba. i6. Medusa. 17. Estrella do mar, ou Asterias. 18. Ouriço do mar.

\section{G E N E R O I. \\ L E S M A. (Limax)}

Carater Generico,

O corpo allongalo, e de rojo, coberto por cima de bum efo cudete de carne, e por baixo tem hum difco longitudinal, e aplainado. Tem bum buraco no lado direito, que ferve as funçöes fexuaes, e para a pafjagem dos excretos. Qub. tro tenteadores póftos por cima da boca.

H

Ste reptil munca tem concha, mas além de ter a fua pelle glutinofa, tem maior groffura, que a da Lefma: a Lefma negra fem concha tem hum mantó arregoado, e $-53$ $\tan$ 


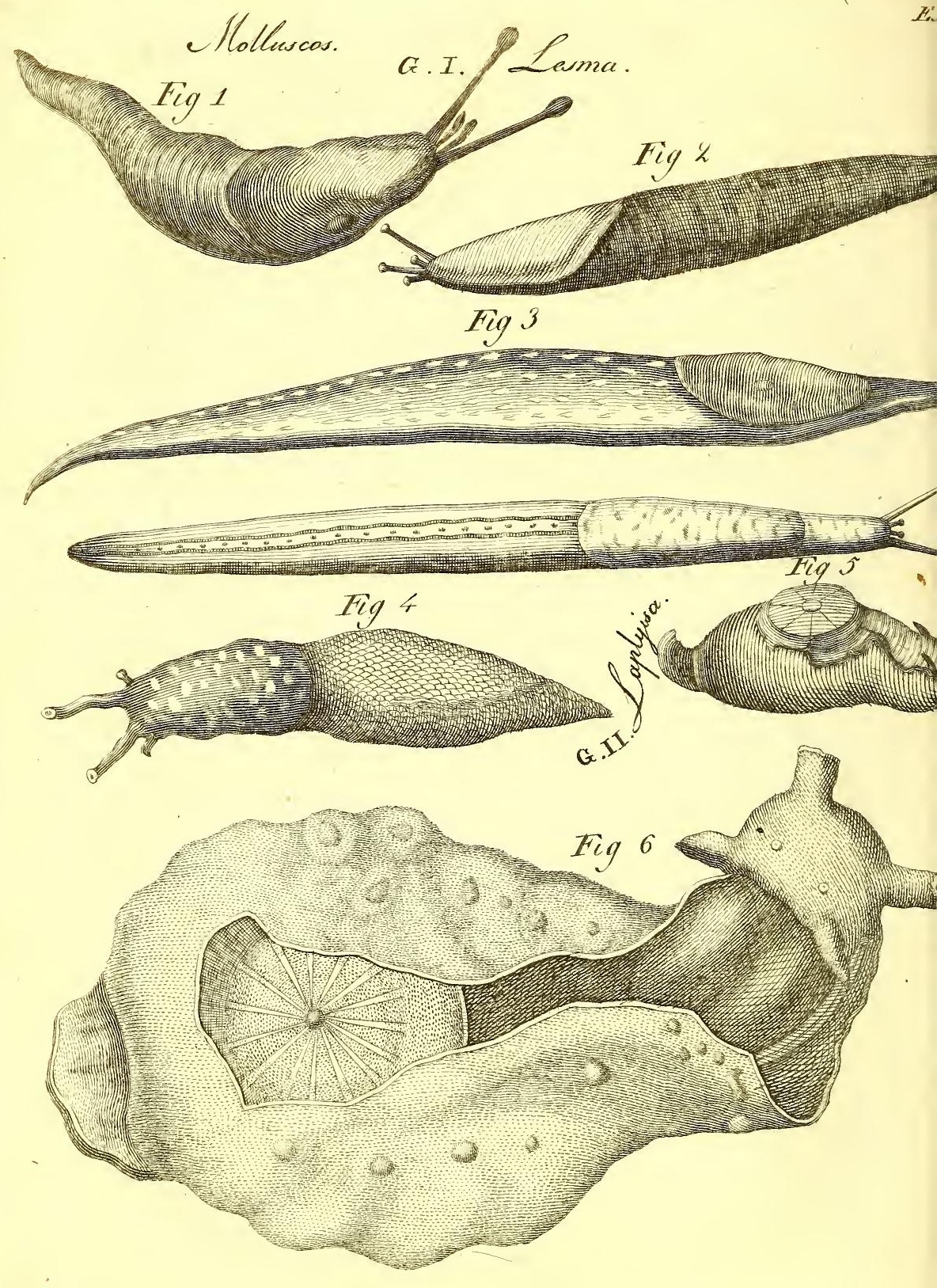


mó duro como coiro, debaixo do qual encolhe a fua cabeça, como em huma concha. Na cabeça, e nas cóftas fe encontraó as pedras das Lefmas, que faó humas pequenas fedras, como perolas, arenofas, e da natureza das pedras de cal. Segundo a opiniaó popular, fervem de remedio nas febres terçẳ, como amuleto, poftas no braço do enfermo. As Lefmas caminhaó lentamente, deixando $\mathrm{em}$ todo - lugar, porque pafraó, fignaes, ou traços glutinofos, e luminofos. A cabeça fe difingue do peito por huma rifca negra. 'Tem-fe defendido, fe bem contra toda a verofimiIhança, que a cabeça, fendo cortada, era logo fubftituida por outra. O feu coito he no fim da Primavera; e ellas trazem, do melmo modo, que os Caramujos, as fuas partes fexuaes no lado direito do pefcoço. O inftrumento do macho fe defenvolve pelo mefmo mechanifmo, que o dedo de huma luva, que fe víra ás veffas : Encontraó-fe algumas vezes penduradas no ar com a cabeça para baixo; e as caudas unidas por huma cafta de atilho glutinofo, e efpeffo, agarradas aos ramos das arvores, onde perfiftem por tres horas, que vem a fer o momento da fecundaçaố. Poem feus ovos em terra. Huma Lefma, empoada de affucar, fal, e tabaco, cahe em convulsóes, lança toda a fua efcuma, e morre.

\section{L е s м negra. Eft. III. Fig. I.}

Tem quafi tres pollegadas de comprído, meia de diametro: a cabeça, e cauda menores que o meio: o coftado convexo; o ventre chato: he lifrado, e rugofo, menos a barriga, em que he mais pallido, e tirante a pardo. Em certo tempo o animal faz fahir de fua cabeça quatro tenteadores. O corpo todo he coberto de hum fluido glutinofo, femelhante, ao que naturalmente cobre as enguias. A Lefma he hermaphrodita : achando-fe em cada individuo

$$
\text { C ii }
$$


ambos os fexos, e no coito fecundaó, e faó reciprocamente fecundados.

He muito commum nos mattos, nas feves, nas adegas, e lugares frefcos, e muito mais nos tempos humidos.

\section{L Е м а ruiva. Eft. III. Fig. 2.}

Chega á grandeza de duas pollegadas, e proporcionalmente mais delgada, que a negra. Tem o corpo arregoado, ou com ligeiras rugas, e a fua cor he de hum ruivo denegrido, menos o ventre, que he alvacento, ou pardofo. Encontra-fe pelas mattas ao depois de chover.

\section{L ез м grande. Ef. III. Fig. 3.}

Tem até cinco pollegadas de comprido. Em certos tempos he de cor cinzenta, e em outros de ambar : a cabeça he reticulada de negro, e tem nas cóftas tres linhas pallidas, e quatro pardas betadas de negro. Mora nos lugares fombrios.

IV. L е s а amarella. Ef. III. Fig. 4.

Tem em toda a fua grandeza pollegada e meia : as cóftas fobrefahem : O ventre mettido para dentro; e a cabeça pequena. Todo o corpo he ligeiramente liftrado de hum amarello luftrofo, mifturado de algum pardo; e entrefachado de manchas pardofas. Entre os arbultos do Nolte, fe topaó abundantemente pelos mattos. 


\title{
$P$ O R T U G U E Z A. \\ G E N E R O II.
}

$2 x$

LE в R E DO M A R. (Laplijia.)

\section{Caracter Generico.}

O corpo arrafador, ou de rojo, coberto de membranas com refegos, ou dobras, que lhe Jervem de cobertura aos bofes. Tem bum buraco no lado direito, em lugar de partes genitues : o anus fituado por baixo da extremidade do coftado. Seus quatro tenteadores póftos na frente.

\section{L в в}

\begin{abstract}
A Sua longitude he de duas pollegadas e meia, e mais de huma de diametro. $\mathrm{O}$ corpo he quafi oval, molle, falpicado de pontos, de huma fubftancia gelatinofa, e cor de chumbo claro. Da maior extremidade fe levantaó quatro excrefcencias oblongas, e efpeffas, que faó os tenteadores, dos quaes dous faó direitos, e outros dous lançados para as coftas. He commum em as noffas Coftas, principalmente na Itha d'Anglefea. Pela força do feu fucco muito venenofo, faz cahir o pello das máos, dos que a tocaó, e lança hum fedor taó intenfo, que caula anxiedades.
\end{abstract}

II. 


\section{L E в R E maior. (Laplifia maior.) Eft. III. Fig. 6.}

O Doutor Bohadfch tendo defcripto em a fua obra, que trata de certos animaes marinos, particularmente efte animal, paffo a dar a fua traducçaó.

A Laplyfia tem no feu todo feis, fete, oito pollegadas de comprido, e a fua largura naố excede tres pollegadas, e algumas linhas. A cor varia em differentes individuos; em huns he pardofa, entremeada de manchas lividas, e denegridas; em outros as manchas lividas faó mais numerofas, e mais claras, e a cor denegrida he mais pallida: entre effes ha alguns, que faó os maiores, cuja cor he de purpura roçagante, e quando fe manejaó, fahe de todo o corpo hum liquido da mefma cor, fendo que as outras lançaó huma mucilagem esbranquiçada.

A cabeça, que he allongada, parece eftar provida de quatro pontas, ou tenteadores carnudos, fe bem a natureza nao the deo mais que dous, que le poffaó, propriamente fallando, chamar tenteadores; porque os outros dous fe formaó, á vontade do animal, do labio carnudo, que pende adiante da boca na parte interior da cabeça : e tambem algumas vezes naó tem femelhança alguma na fua figura, nem ás pontas, nem aos tenteadores.

Os dous polteriores fá feitos como orelhas, por ferem cylindricos na bale, e alargados na ponta, encolhendo-fe na extremidade; e para a parte fuperior faó alguma coufa finuofos, de forte que de maneira alguma fe devem chamar orelhas; por naó haver cavidade alguma, que penetre interiormente, mas fo huma pequena finnofidade. Eftes tenteadores tem tres linhas de comprido, tres de groffura: a fua difanicia da parte anterior da cabeça he de nove linhas, e o apartamento de hum, e outro de feis. Tres li- 
linhas abaixo dos tenteadores, que tem a fórma de orelhas, fe achaó os olhos, que faó perfeitamente negros, rodeados de hum circulo: tem meia linha de diametro, e faó vifiveis fem luneta. O pefcoço, que he hum plano convexo, tem dezefeis linhas de comprido, e huma pollegada de largo. Ao lado direito, e inferior do pefenço, oito linhas abaixo dos tenteadores auriformes, fe levanta huma membrana efpeffa, carnuda, de mais de huma pollegada de groffura, a qual fe conduz ás partes pofteriores da Laplyfia, e de lá volta até o lado efquerdo do pefcoço, e nelle fe termina, e ferve para vefít o refto do corpo, como de huma efpecie de cuberteira. Póde-fe-nos permittir dar a efta membrana o nome de capa, vifto que ella algumas vezes fe eftende, e faz hum reborde, e outras vezes fe encolhe, ou contrahe ao gofto do animal, de fórte, que as partes trazeiras da Laplyfia, fe achaó inteiramente cobertas defta capa, ao ponto de fe naố poder ver coufa alguma de feu feitio, ou melhor, quando a capa eftá lançada para traz, eftas partes pofteriores ficaố defcobertas, e tudo, quanto antes eftava occultro, fe acha agradavelmente expofto á infpecçaó dos cuxiofos, que pódem ver. 


\section{G E N E R O III. \\ LIMAó DO MAR. (Doris.)}

\section{Caracter Generico.}

O corpo de rojo allongado, e chato por baixo. A boca pofta adiante por baixo. $O$ anus se acha por de traz rodeado de pefanas. - Dous tenteadores por cima do corpo sa dianteira, efeitos de maneira, que fe recolbem nas fuas aberturas.

\section{L I м а ơ enverrugado. Eft.IV. Fig. I.}

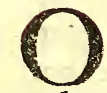

Corpo he allongado, meio cylindrico, convexo, arredondado nas extremidades; a parte fuperior, ou as cóftas coberta de verrugas, ou de excrefcencias femelhantes a verrugas. A borda lateral redobrada, femelhante a hum Ouriço meio dobrado. Tem o mefmo movimento que as grandes Leimas, fendo o membro, que ferve de pé, oval, alongado, com a margem plana. 'Tem oito tenteadores em torno da boca, e tres deftes curtos. Mora nas aguas, perto de Aberdeen, e fe acha commummente nos mares do Norte.

\section{L I м а б de duas laminas. Efl. IV. Fig. 2.}

O corpo oval efcabrofo por botóes, e alguma coufa abaulado. Dous tenteadores na parte dianteira do corpo. $\mathbf{O}$ anus atraveffado por baixo da parte pofterior do corpo, peftanudo com fronxéis fingellos. Mora nas Solhas, ou Patruças do Oceano da Noruega, e particularmente nos feus figados: Encontra-fe frequentemente nas pedras. (Agora Limaó fufco.) 


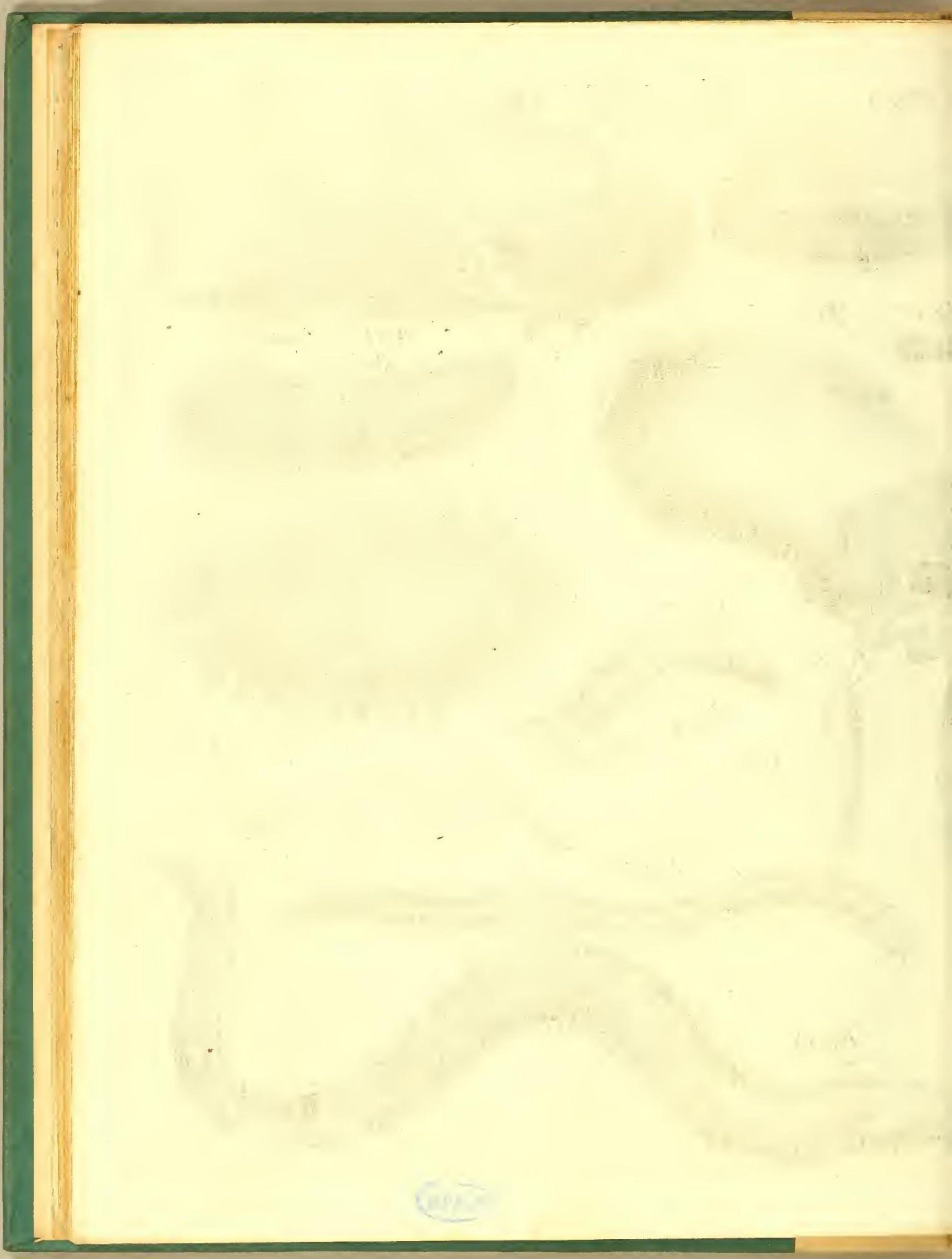




\section{IIL L I M A ô Argus. Ef.IV. Fig. 3 .}

Todo o corpo do Argus he obliquamente aplainado; ou perpendicularmente comprimido. O meio tem feis linhas: de groffo, e dahi fe adelgaça infenfivelmente, acabando nas. fuas bordas com meia linha de groffura. 'Tem tres pollega-. das e cinco linhas de comprido, e duas pollegadas de largo. As coftas brillhaó com huma cor viva efcarlate; e a barriga goza da lindeza da cor amarella agradavel da argilla, e ambas fao formofamente betadas de manchas negras, e brancas.l A fubftancia inteira do corpo he conreacea, e fóli da, a qual, cortada pelo meio, apparece por toda a parte tinta de amarello açafroado. Ao redor toda a circumferencia he molle, e porifro o animal á fua vontade toma dobras differentes. A cabeça, que em todos os animaes fe conhece com facilidade pela fingularidade do feu feitio, naó fe póde decidir no Argus, quando as coftas fazem face ao efpectador, vito que a fórma oval do corpo, que tem o melmo diametro em toda a circumferencia, fenaó diftingue da cabeça. Além difto os tenteadores, que fe vem nas duas extremidades, indicaó igualmente a cabeça; mas, virando-fe o animal, fe conhecerá a cabeça na parte, donde fahem os tenteadores affilados, ou adelgaçados. A metade, ou a bafe deftes tenteadores, he branca, mettida em pequenas cavidades redondas, formadas da fubftancia da cabeça, em profundeza de duas linhas. A fira extremidade he totalmente falpicada de régro, refaltada da cavidade. Segundo o que pude defcobrir, ajudado de huma luneta, e por minhas conjecturas, os feus pontos negros em a extremidade, que he mais groffa que a bafe, fao outros tantos olhos, os quaes chegaó a fer mais de cem, e me obrigáraó a dar-lhe o nome de Argus.

Mas, tocando-fe com os dedos, ou com qualquer ouD tra 


\section{\&6 HELMINTHOLOGIA}

tra coufa eftes tenteadores fe recolhem em continente para dentro das cavidades, donde parece que eftas já foraó deftinadas pelo Author da Natureza, para lhes occultar os olhos, fegundo a occafró, e para defendellos de toda a injuria de fora. Por cima da cabeça fe acha huma excrefcencia mamillar", fituada para a barriga, em difancia de cinco liwhas da borda. No méio defta eminencia fe vê huma pe. quena abertura oval, que ferve de boca ao Argus. Aos dous lados da boca eitaó poftos outros tenteadores, igualmente delgados, e de cor d'argilla, que parecem fer definados a apanhar o fuftento, e a trazello á boca do animalejo; porque eftando os ollos poftos por baixo da cabeça, naó poderia perceber os objectos proximos, e por eite motivo fe acha provido deftes tenteadores, para procurarem a fua preza.

Paflamos á parte, que the ferve principalmence de adorno ; e que o diftingue dos outros animaes. Em a parte das cóftas, oppofta á cabeça, em diftancia de quatro linhas da borda, fe encontra huma abertura oval de oito linhas de comprimento e cinco de largo. Do meio defte buraco fe eleva hum tronco carnudo de cor esbranquiçada, longo quatro linhas, e largo huma e meia, que fe divide em dous grandes ramos, e o du direita fe fubdivide em oito, o da cfquerda em feis raminhos menores, que a final fe rematao em outros menores. Além dos ditos tem hum groffo ramo, que, fahindo do meio do primeiro tronco, toma a fua direcçaó para a cabeça. Em todos os ramos, affim maiores, como menores, fe achaó muitos pontos negros vifiveis aos olhos, que concorrem muito para a belleza defta parte florida; mas naó pude decidir, ainda com o auxilio do microfcopio, fe os pontos eraó furados, fe bem naó duvido, que fejaố tantos orificios de vafos abertos, e pontos dé refpiraçaô, e que todo o fobredito aparelho de ramos naó fejaó bofes. Em quanto o Argus fe acha nas aguas do mar, abre, e eftende efte maravilhofo ajuntamento de bofes ef-

ten- 
tendido, mas logo que delle o tiraó, e tocaó com o dedo, fe contrahe em fórma de coroa, e continuando-fe a manejallos, por pouco que feja, fe occultaó inteiramente na abertura oval, que entao fe acha fechada. Tornando-fe a deitar n'agua, a abertura fe alarga logo, e a ramificaçaó dos bofes, que eftavaó óccultos, fahindo infenfivelmente, fe alongaó, e le eftendem.

Por efte detalhe do Argus fe faz claro, que elle nao correfponde a algum genero dos Zoophytos defcriptos pelo illuftre Cavalleiro Linne : Seja-me por tanto concedido exprimir alguns fignaes caracterifticos pela definiçaô fegainte : O Argus he hum genero de Zoophytos, cujo corpo he obliquamente aplainado, provido de quatro tenteadores adelgaçados, dos quaes dous na parte inferior da cabeça trazem os olhos; e dous fimples, fituados na parte fuperior perto da boca. T $\mathrm{Tm}$, quando muito, bofes ramificados jünto ao Anus. (Até aqui o engenholo Bohadích).

Todos os animaes defte genero faó de hum amarelló lavado, ou bem carregado, e quando elles fe dobraó em oval allongado, o que acontece muitas vezes, fe affemelhaó de alguma fórte ao Limaó, o que fez que os Pefcadores the deffem efte nome. acth

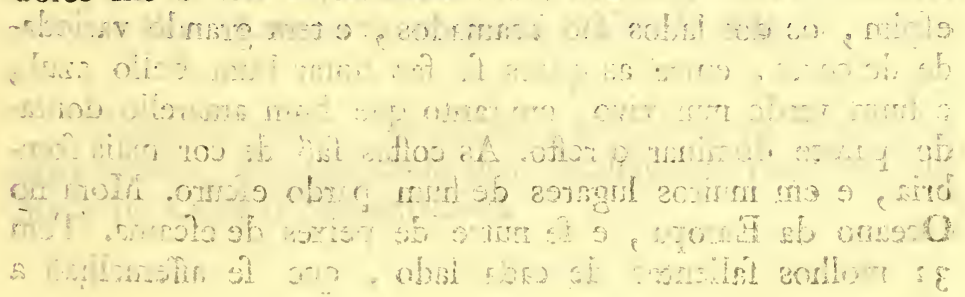




\section{G E N E R O IV. \\ A P H R O D I T A. \\ Caracter Cenerico.}

O corpo anda de rojo, e he oval, tendo por cada lado mui- tas partes pequenas falientes em feiçaó de pés. A boca, que be cylindrica, e fe recolbe destro, faz a extremidade: gowa de dous tenteadores enjedecidos.

\section{A PHRODIT de picos. Eft. IV. Fig.4.}

A Liguns a chamao Murganbo do mar. He de fórma oval, avança á grandeza de quatro a cinco pollegadas. A barriga, que fobrefahe no meio, he coberta de huma pelIe núa. A fua fubftancia he pouco firme, e reveftida pelo meio das cóftas de filamentos pilofos; e curtos; porém nais compridos nos lados, e todos afaz engrovinhados, $c$ firmes. Os das coltas faó todos direitos, como os do porco efpim, os dos lados faó acamados, e tem grande variedade de cores, entre as quaes fe faz notar hum bello azul, e hum verde mui vivo, em tanto que hum amarello dourado parece dominar o refto. As coftas faó de cor mais fombria, e em muitos lugares de hum pardo efcuro. Mora no Oceano da Europa, e fe nutre de peixes de efcama. Tem 32 molhos falientes de cada lado, que fe affemelhaó a pés. 
II. Aphrodita efcabrofa. Eft. IV. Fig. 5.

He allongada, tendo as coftas groffeiras, e guarnecidas de efcamas. O corpo he hum pouco mais comprído, que o do Onifco: as cóftas faó cobertas de vinte efcamas nudes, póftas revefadamente. Tem vinte pés de cada lado. Encontra-fe nos mares de Flandres: algumas vezes fe apanha na altura de Brighthelmftone do comprímento de huma pollegada.

III. Aphrodita efcamosa. Eft. IV. Fig. 6.

$\mathrm{O}$ corpo he hum pouco alongado, coberto de $24 \mathrm{ef}-$ camas ovaes, fixas, feguras pelo lado exterior. Tem de cada lado 24 pés, tres curtos, e com unhas. Os tenteadores fá dous, mui curtos, e abertos pelo meio. A boca envolvida de huma abertura. A cauda remata com algumas fedas mui curtas. Encontrarfe no Oceano da Europa.

\section{Aphrodita atelbada. Ef.IV. Fig. 7 .}

Parece-fe com a precedente, menos em ter as efcamas mais unidas, defpegando-fe mais facilmente. Varia na coro Mora no Oceano Septentrional. 


\section{G E NERO V. NER E I D E.}

Caracter Generico.

Animal de rojo, allongado, e de igual largura. Os tersteadores dos lados fao bm feiga ó de pinceis. A boca fóma a extremidade, e efa be provida de bum gancho.

\section{Nereide luz da noite. Ef. IV. Fig. 8.}

\section{TH}

Stes faó os animalejos phofphoricos, que de noite ilIuminaó o Oceano, para o que concorrem muito o feu grande número, e a fua extraordinaria agilidade, de acordo com a fua qualidade tranfparente, e reluzente; porque huma taffa d'agua do mar póde conter milhares deftes animalejos. Alojaó-fe hum fem número nos interfticios das ef́camas dos peixes, e a elles he verofimilmente, que os peixes devem a qualidade de luzirem nas trevas. Examinei com attençaó hum peixe, que acabava de fer apanhado, cujo corpo eftava todo coberto, e, fazendo ao depois minhas obfervaçóes na obfcuridade, achei que eftes animalejos fe moviaó, e volteavaó com huma ligeireza admiravel, mas que fe fubtrahiaó logo á nof̂a vifta limitada, cegando fua multidaó brilhante os olhos fem dúvida, e fua extrema pequenhez encobrindo-os aos norros exames. He bom advertir que, quando a humidade unctuofa, que cobre as efcamas dos peixes, fe acha efgotada pelo ar, fenaó vem mais eftes animalejos, e os peixes naó reluzem mais de noite, fervindo-lhe talvez efta materia de fuftento, em quanto vivos, do mefmo modo, que elles mefimos faó o bifcato de muitos ani- 
maes marinos. Elles naó reluzem de dia; porque os raios do Sol apagaó a fua luz a pezar da fua multidaó. Que refpeito, que admiraçaó naó devemos a efta potencia infinita, e creadora, que elpalhou por todos os mares efta profufaó de entes animados, imperceptiveis, infinitamente miudos, e que provaó o defeito da louca vivacidade da efpecie humana!

\section{Nereide das lagoas. Ef.IV. Fig. 9.}

O támanho do corpo he como o do figado de hum leitaó pequeno: he tranfparente, e por aflim dizer, articulado, e de cada lado em todas as articulaçōes, tem hum pé clirto, e enfedecido ; interiormente parece confiftir d'alguma maneira de articulaçóes ovaes, e de humas coftas formadas de duas linhas redobradas por fóra. Mora nos charcos argillofos: conferva-fe debaixo da terra, onde pelo feu continuo movimento faz apparecer huma das fuas extremidades; e quando fe extrahe, ella fe enrofca. He frequente em Suecia.

\section{Nereide barbada. Eft. IV. Fig. IO.}

O corpo he vermelho, alombrigado tem I 50 barbas, e fe fornece em cada lado de duas ordens de fedas. Em os da cabeça fe contaó déz fios, e ao redor da boca huma grande quantidade duas vezes mais compridos, que os outros. $\mathrm{Na}$ Noruega fe pega aos rochedos por baixo do mar: e vomita hum liquor vermelho, que tinge as aguas. 
IV. Nereide azu. Ef. IV. Fig. II.

Mora no Oceano, onde deftroe as Serpulas, e tam. bem as Urillas.

\section{Neretde gigantefca. Eft. V. Fig. I2.}

Efta he huma efpecie particular, que fe alimenta dos velhos mouróes, fincádos no mar: ella os fura, e delles tira o feu fuftento, donde nafce o chamarem-na Bixo do mar', ou Nereide. Defde a cabeça até a cauda faó ouriçadas, por cada lado, de pequenos molhos terminados em tres pontas, que fe parecem com os pincéis, de que fe fervem os Pintores, e faó compoftos de fedas luzentes de diverfas cores. A parte fuperior do corpo defte Verme he toda coberta de pe: quenos pellos. Os anneis, de que fe fórma, laó eftreitamente apertados, e molles ao tacto. As tres ordens de pequenos molhos, que acabu de defcrever, fazem vezes de pés ás Nereides, que delles fe fervein, para fe adiantarem, como os peixes das fuas barbatanas. 


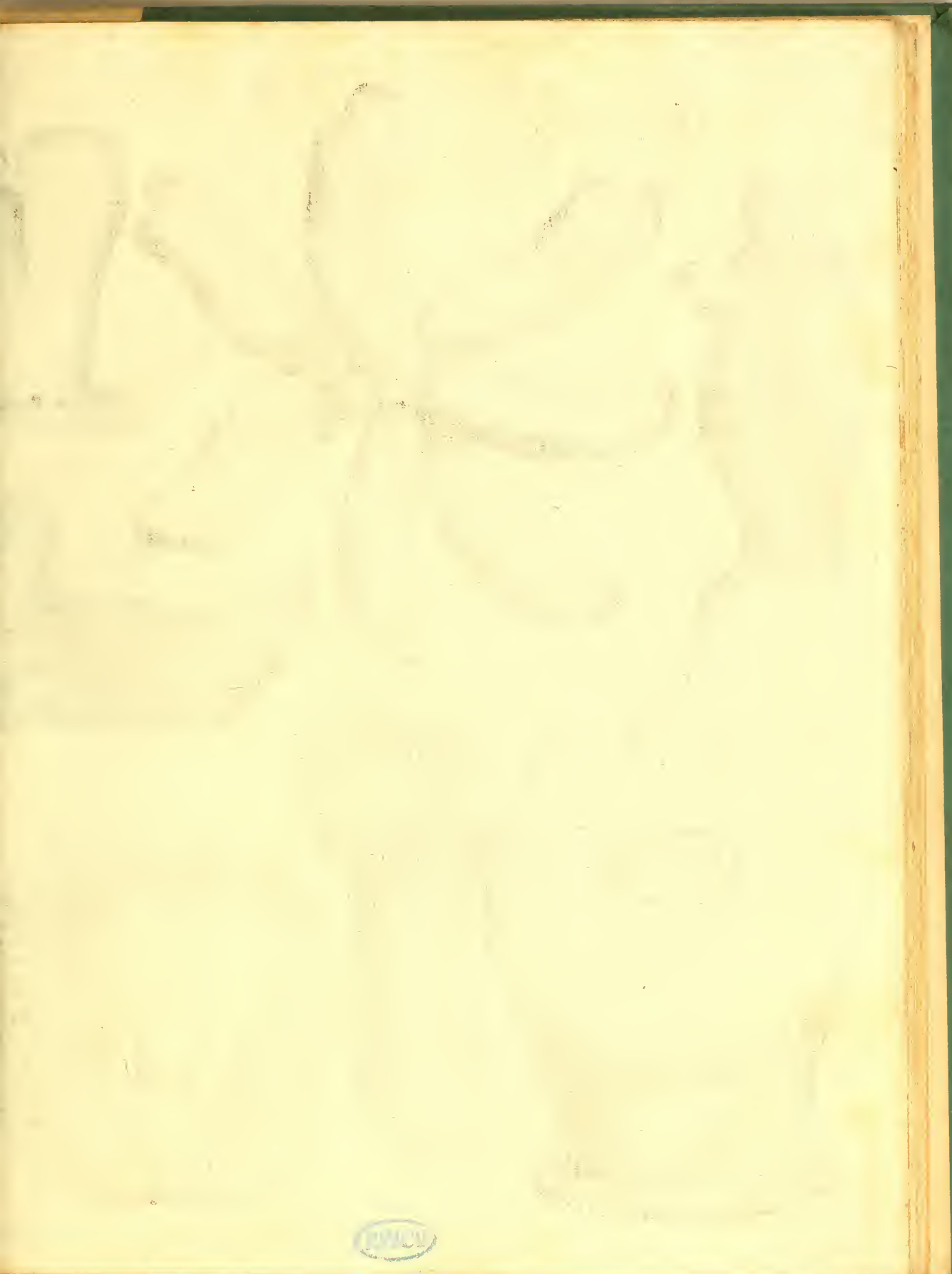




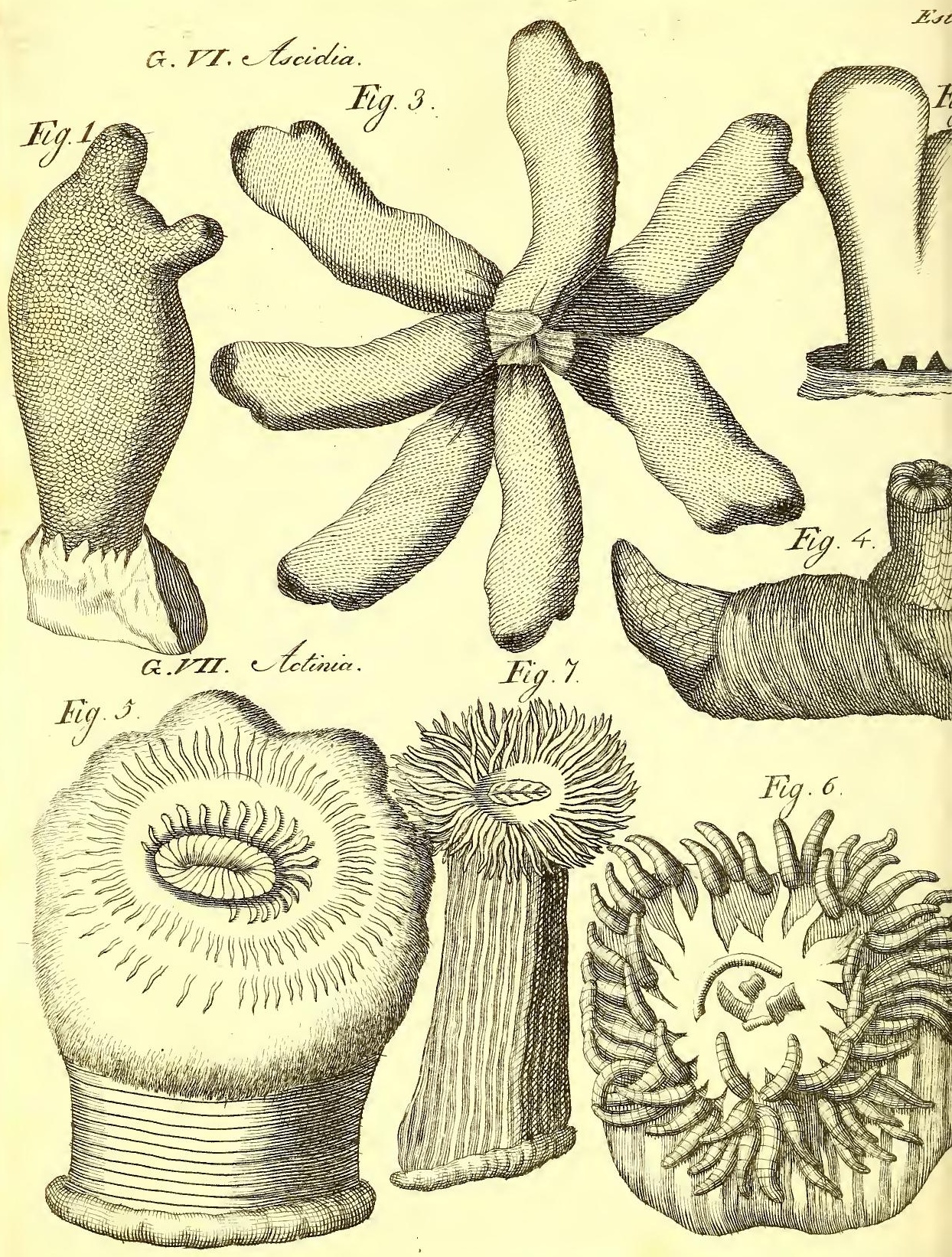




\title{
G E N E R O VI.
}

\author{
A S S C I D I A.
}

Caracter Generico.

Corpo fixo, roliggo, embainbado, com duas aberturas no ab to, buma fituada mais acima; e outra em baixo defta.

\section{Ascidia mamillar. Eft.V. Fig. x。}

Rdinariamente tem tres pollegadas de comprido, huma e fete linhas de largo; e a fua figura he oval. $\mathrm{Na}$ parte fuperior tem duas excrefcencias mamillares, ou orgä̉os avançados, dos quaes hum, fituado no alto do corpo, tem hum orificio em fórma de cruz; e o outro, que eftá pofto atraveffado hum pouco mais abaixo, he triangular. Os labios dos dous orificios fá rodeados de muitos pellos fedeudos, de cor de argilla, longos de huma linha, mas fem ordem regular. Toda a parte exterior do corpo he grofeira, femea$\mathrm{da}$ de pequenos botóes, ou mamillos allongados, cor de fogo. A extremidade oppofta dos orgáos, ou a bafe he provida de pedunculos de diverfas fórmas, por cujo meio efte Zoophyto fe apega fortemente aos rochedos, ou á ontros córpos, de modo que fenaó póde arrancar fem os deftruir. A fua pelle he taố efpeffa, e dura, como o couro, fazendo a maior parte da maffa do animal. Quafi fe the naó diftinguem as partes interiores, menos huma certa parte de fórma inteftinal, que, fahindo hum pouco abaixo do orificio do orgaó fuperior, defce quafi até a bafe, e dahi fe eftende atéo lado direito, e tem a fua inferçaó no orificio, ou orgaó inferior. Donde nos he permittido conjecturar, que o orgaó fuperior 


\section{H E-L I I H $O$ LOG I A}

faz o officio de boca; e o inferior o de anus. Naó fe ferve delle para o fuftento.

\section{Ascidia gelatinosa. Ef.V. Fig. 2.}

Efta efpecie de Afcidia chega a huma pollegada, e a dez linhas de comprimento, e dezafeis linhas de largo. He de figura comprimida, unida por toda a parte, tinta de huma bella cor de fogo; tranfparente, como gelea. Sua fubftancia he a mefma, que a dos Bofes do mar de Mathiolus, e de outros, ou de huma confiftencia, entre a gelea, e a cartilagem. Os feus orgăos faó allongados, providos de huma fenda, ou orificio longitudinal. Os labios do orificio, que faó enrugados, naó tem pello algum. Neita efpecie, como na precedente, fe encontraó diverfos pedunculos em a bafe, por ajuda dos quaes o animal fe apega a outros córpos.

\section{Ascidia intefinall. Eft. V. Fig. 3 .}

Todo o corpo he huma membrana inteira, e efpeffa, feita em fóma de inteftino de quadrupede, de cor efbranquiçada. Cortando-fe a membrana pelo comprimento, fe percebe hum canal membranofo, cheio de huma materia negra, a qual, vindo do orgaó a té a bafe, e daqui, curvando-fe, fe vai terminar por huma inferçaó ao orgaó inferior. Eftes orgăos fe achaố algumas vezes fortemente encolhidos, e outras muito froxos, e de tal fórte que, nem por iffo me appareceo vez alguna a abertura intermediaria, feja que manejaffe efte animal fóra da agua, ou dentro della, pois nunca percebi que eftes orgáos refipirafem agua, como faz a Afcidia mamillar. 
IV. Ascidia Campeftre. Eff.V. Fig. 4.

O corpo he allongado, cylindrico, e de cor tirando para parda. As fuas extremidades faó efcabrofas; huma dellas fe ergue : o meio he lifo, a parte inferior aplainada. Mo ra em os mares do Norte.

Os animalejos pertencentes a efte genero feringaó a agua, que recebem, como fe forfe pelo cano de huma fonte, e os animalculos, que faó nelles contidos, parecem ter fido o feu fuftento. A dilataçaố, e contracçaố dos feus corpos os fazem parecer de huma variedade de fórmas differentes.

\title{
G E N E R O VII.
}

\author{
A C C T I N I A.
}

Caracter Generico.

O corpo allongado, roligo, e pegado a outra fubfancia. A parte Juperior capaz de dilataģaó, rodeado por dentro de tenteadores fem numero. $A$ boca, que be a fua unica abertura, guarnecida de dentes gancbosos. A tromba cylindrica, e radiosa.

\section{$\mathrm{N}$}

As Actinias o movimento progreflivo he taó lento, que he embaraçofo percebello. Dentro de huma hora apenas avançaó huma pollegada. Parece que ellas todas, quando fe tocaó com as mãos, naó fazem a impreffaó dolorofa de algumas, o que á eftas fez dar o nome de Ortigas do mar. Eftes Mollufcos molles, flexiveis, fá capazes de tớ$\mathrm{E}$ ii das 


\section{H E.L M I THOLOG}

das as caftas de fórmas. Saó viviparos, fuftentaó-fe de conchinhas, abrem a.boca mais, ou menos, conforme o volume da preza, que engolem, e lançaó ao depois a concha pela mefma abertura. Tendo a boca aberta, fe vem os tenteadores da Attinia, que nefte eftado fe affemelhaó a huma flor aberta, o que lhe deo o nome de Peixe flor, e de Anemomas do mar.

\section{Actinia velba. Ef. V. Fig. 5 .}

Tem rugas orbiculares, e huma quantidade de trombas miudas. He toda rodeada de coftellas, apartadas huma da outra meia linha,e por baixo fe acha provida de huma bafe com hum pedunculo, que paffa alguma coufa ao corpo em largura, e por cujo meio fe pegava ao fundo do copo, em que fe poz. Confervei vivo hum animal deftes, por mais de quatro mezes, e nefte tempo fe tranfportava de hum ao outro lado do copo.

\section{Actinia gatefca. Ef. V. Fig. 6.}

Poder-fe-hia, ao que me parece, definilla. $=$ Actinia com rugas longitudinaes, trombas longas, e grofas. $=$ Tocando-fe com precauçaó o fim de qualquer das trombas com hum páo, o animal, chupando-o, fe afferra com tanta fortaleza, que, puxando-fe brandamente, póde allongar com muita grandeza a fua tromba. Por eftas trombas, e fua fituaçaó ao redor da borda, e da boca, eftes animaes parecem ter refpeito com os polvos, a naó ferem, proporçaó guardada, mais curtas que os braços dos polvos, e mais numerofas. Apanhaó-le frequentemente na bahia de Broweshaven, e de Goeder, e de todas as efpecies, e cores, como vermelhas, brancas, auroras, cor de rofa, pardas, com pout 


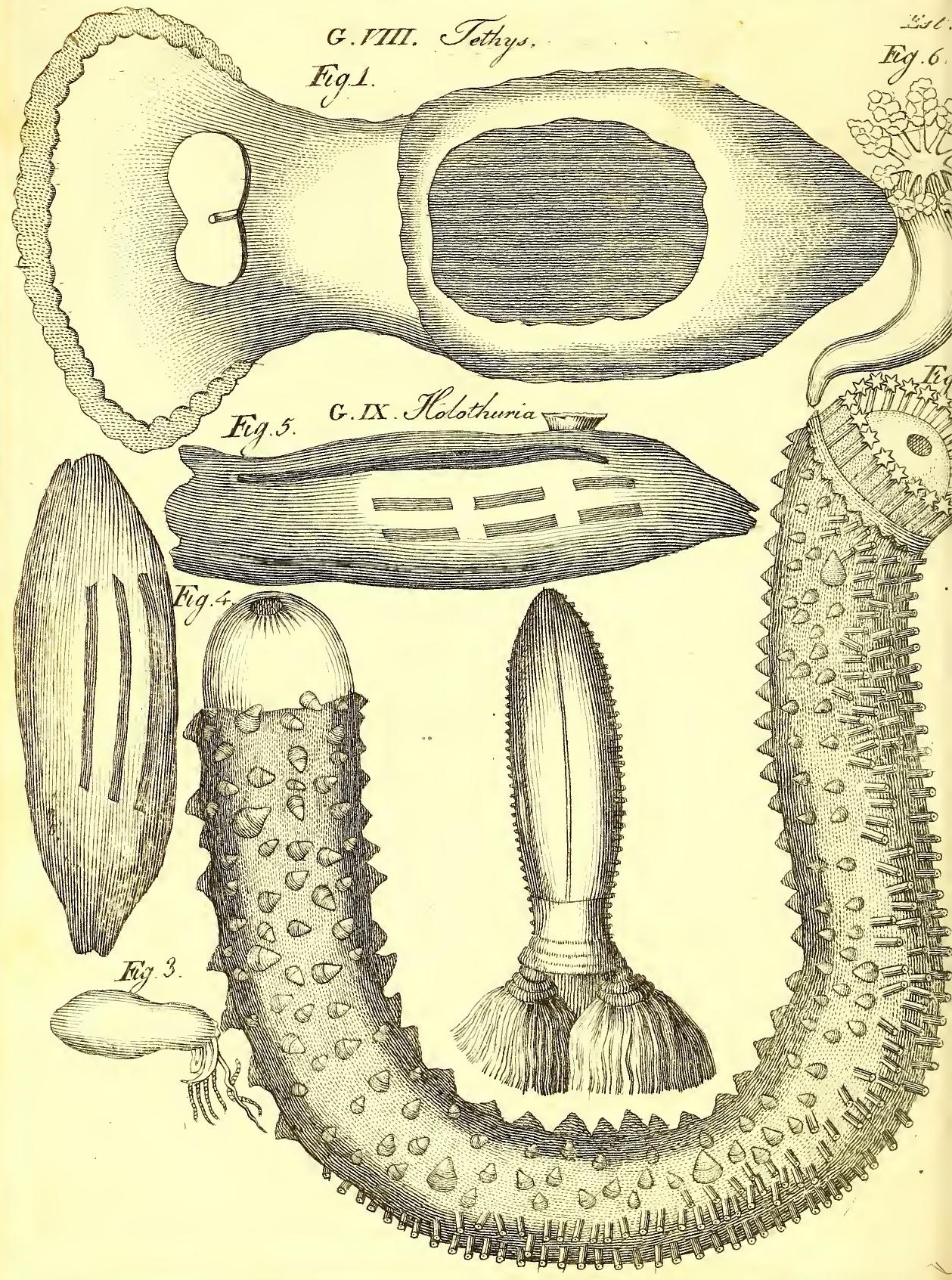




$$
P \cap R \text { T U G E } Z \text { A }
$$

pas , \&c., e ordinariamente eftaó pegadas ás pedras, ou ás OAtras.

\section{Actrinis enfraquecida. E $2 . V$. Fig. 7 .}

Efe animal he de huma figura proxima á cylindrica, tem eftrias longitudinaes, defde o pedunculo até a raiz dos tenteadores, ou numerofas trombas, que faó como fios, e eftendidas, de forte, que daó ao animal huma apparencia de flor, e a boca, pofta no centro do difco, corrobora a femelhança. O pedunculo tem a fua borda ondeada, e excede a circumferencia do corpo.

\section{G E N E R O VIII. TETH I S.}

Caracter Generico.

o corpo despegado, hum tanto comprido, carnudo, fem pés. A baca Se termina por buma tromba cylindrica, por baixo - de bum labio eflendido. Duas aberturas no lado efquerdo do pefroge.

\section{Тетніз framja. Ef.VI. Fig. I.}

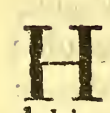

E totalmente de hum branco claro, fóra a borda do labio, e tem feis pollegadas de comprido. O labio eftendido para diante da cabeça, femelhante a huma membrana franjada, naó ferve de pequeno adorno ao animal, e fe eftende a quatro pollegadas e meia de largura, com tres fómente de comprimento A borda dos dous lados he chanfrada, 
ou recortada, e mais grofa, que o labio, por cima do qual fe ergue, o que faz parecer hum galaó de ouro, ou de prata en hum chapeo, donde fe julga que he alguma coufa mais, que a continuaçaó da membrana, que fórma o refto do labio. A cor da horda franjada he de huma mifura de negro, e cor d'argilla, de forte, que a parte interior recortada he negra, marcada de alguns pontos, cord'argilla ; a parte oppofta, igualmente recortada, he inteiramente negra, e a porçaó intermediaria brilha de huma cor de onro brilhante. Efta elegante variedade de cores fó fe faz notar do lado da borda, que correfponde á fituaçaó inclinada do animal ; porque do lado oppofto o animal he inteiramente negro. A membrana, que faz o refto do labio do animalejo, confta de fibras, brancas, efpeffas, de huma fubstancia quafi tendinofa. Efta Tethys habita no mar alto, onde fó fe deixa ver nos grandes ardores do Sol, e fe apanhaú com os outros peixes nas redes. Donde he precifo, que fe pefque defpegada, e crrante nas ondas, com tanto, que fe naó cheguem aos rochedos com as fuas redes, quando a querem pefcar. Naó duvido que ellas, como a Lernea, fenró apeguem aos rochedos, ou ao fundo arenofo, ou argillofo do mar, e que algumas fenaó defpeguem de fi mefmas, ou pela violencia das ondas. Diverfas efpecies de Sargaços, ou Algas lhe fervem de fuftento, que he o que fé tem podido defcobrir pelo contheudo do feu eftomago. Percebe-fe que ella naó fe fuftenta de conchas, por lhe faltar o fegundo eftomago, armado de dentes, e que os naó tem na bocca. Ella digere facilmente as fibras tenras das Algas, que ainda nos eftomagos mais debeis achando-fe macerados pela miftura da agua do mar, e dos fuccos homogeneos, fe diffolvem quafi per fi mefmas. Ninguem fe ferve dellas, como fuftento, ainda que os pefcadores naó lhe attribuaó alguma má qualidade. Todavia, fe pela fua eftructura eu devo decidir, fe ella fe poderia comer fem inconveniente, eu naô duvidaria feguir a parte affirmativa, e tanto, quanto naó tem a glan: 
glandula venenofa, nem o cheiro defagradavel da Lernea. Além do que, todos os animaes, ainda os mais venenofos, fe pódem comer fem perigo, com tanto que the hajao de tirar as partes venenofas, o que affaz fe demoftra pelo ufo das viboras, e d'outras ferpentes. Aflim, naö falta çuem certifique que toda a precançaó he baldada à efte refpeito; vifto que ns animaes, que abundaó de veneno, fó offendem ao homem, em quanto vivos; e entaó ainda he precifo irritallos. Concordo com tudo de boa vontade que a Tethis feria dura de fe digerir pela fua eftructura fibrofa.

\section{GE N E R O IX. \\ H O L O T H U R I A.}

Carąer Generico.

O corpo be despegado nî, e corcovado, terminado pelo anus: tem muitos tenteadores em buma das extremidades. A boca be pofta entre os tenteatores.

I. Holothuria tremula. Ef.VI. Fig. 2.

Em commummente oito pollegadas de comprido, eftando morta; mas viva, fe eftende a mais de hum pé, ou bem fe encolhe em hum bolo. Sua figura he cylindrica, com hum diametro totalmente iggual á huma pollegada, e algumas linhas. As coftas, de hum pardo carregado, faó ornadas de mamillos carnudos, de figura pyramidal; e de cor ignalmente carregada na bafe, mais branca na ponta. Póde-fe notar que os tem de duas differentes grandezas, os grandes fe fi. tuaó pelo longo das coftas, quatorze de cada lado; apartados feis linhas huns dos outros, quando o animalejo fe en- 
colhe; mais de oito, quando fe dilata. Achaó-fe poftos outros femelhantes, efpalhados fem ordem. Os menores faó igualmente repartidos por toda a parte nas coltas. De todos decorre huma mucilagem esbranquiçada, que ferve de lhe humedecer o corpo. Donde parece que todos os mamillos, acima ditos, faó outras tantas glandulas, providas de hum tubo excretorio com huma abertura taó pequena, que a naó pude defcobrir, ainda ajudado de huma lente ordinaria. Que elle faó abundantemente providos de diverfos mufculos fe conhece; porque os levanta, ou abaixa a vontade. O eixo, e o diametro da bafe em os grandes mamillos, quando eftaó levantados, tem tres linhas. A barriga, ou a parte oppolta ás coftas, he de hum pardo alvacento, e toda femeada de pequenos tenteadores cylindricos, taó juntos, que apenas daraó lugar a huma cabeça de alfinete. Só tem huma linha de diametro, e quatro de comprido, e faó de huma cor branca brilhante, menos na ponta, por fer de huma cor carregada, e feitos em fórma de caixa. Por meio deftes tenteadores, a Holothuria fe agarra no fundo do mar, de maneira que as tempeftades naó a pódem arrancar, o que de outra fórte lhe havia de acontecer ; porque efte Zoophyto fe mantem perto das praias, onde a agua naó tem maior altura que a de leis pés. Ora, apegando-fe ellas a outros corpos por meio dos feus tenteadores abdominaes, devem eftes ter a ponta feita, em encaixe, como os da Ciba. Os Ouriços, e as Eftrellas tem os feus, por cujo meio fe agarraó fortemente aos outros córpos.

Além da fiñaçaó da Holothuria no fundo do mar, cuja fituaçá ella conferva tambem em hum vafo cheio de agua falgada, á qualquer fe fará evidente, que eu temerariamente naó teinho dito, qual era o ventre, e quaes as coftas do animal: o que de outra forte em hum corpo cylindrico fe diria com muita difficuldade. Mas, como todos os animaes caminhaó uniformemente, apoiando-fe fobre o corpo da parte da terra, e que efte tem igualmente efta parte abaixada na mefma, 
onde fe vem os tenteadores cylindricos, he claro que, efta parte he o ahdomen, ou ventre defte Zoophyto. Finalmente, os tenteadores, affm do ventre, como das coftas fe levantaó, e abaixaó á proporçaó da vontade do animal, donde naó he huma conjectura leve, concluir que elless faó providos de mufculos para levantar, e deprimir, e principalmente, vifto que todos os fobreditos tenteadores defapparecen ao depois de morto. Vê-fe tambem que todos os curiofos de Phyfica nos tem dado figuras de Holothurias mortas, e nenhum delles thes attribuem tenteadores. Tambem naó duvido que o illuftre Linne dera o Caracter genericó da Holothuria por algum individuo morto ; pois fe naó lembra dos tenteadores.

\section{Holothuria bexiga. (Pbyjalis.) Eft.VI. Fig. 3 •}

O corpo he oval, tirante a triangular, d'huma tranfparencia de vidro: as coftas faó em efpinhaço agudo, d'hum verde carregado, do qual fahem quantidade de nervos, por diante o corpo arroxado. A tromba efpiral, roxa, para a parte da extremidade groffa, onde tambem fe achaó muitos tenteadores de hum comprimento defigual. Os mais curtos fe adelgaçaó, e faó mais groflos; os medianos faó capillares, tem a ponta de cor de argilla, e de fórma globulofa : os mais longos faó filiformes, cujo intermediario he mais groffo, e tem dous tantos de comprido. Brown na Hiftoria de Jamaica, a chama Bexiga diafana de muitos tenteadores, tendo a figura do ventre humano: por cima tem hum crifta cellulofa, por baixo da outra extremidade pendem muitos tenteadores ramofos. Efta efpecie mora nos mares. 


$$
42 \text { HELMINHOLOGIA }
$$

\section{Holothuria Thalia. Efl. VI. Fig. 4.}

A crifta comprimida com linhas lateraes naó intzrrompidas. Mora no mar.

\section{Holothuria Caudata. Ef. VI. Fig.5.}

A crifta comprimida com linhas lateraes interrompidas: Encontra-fe nos mares d'America.

V. Holothuria de cinco ordens. (Pentactes.) Eft.VI. Fig. 6.

A boca rodeada de dez tenteadores, os quaes o feu corpo tem em cinco lugares. $O$ animal he roxo, meio oval, ou algum tanto cylindrico, tomando diverfas figuras. A boca rodeada de dez raios efpinhofos na ponta. $\mathbf{O}$ corpo longitudinalmente he falpicado em cinco lugares de verrugas oeas amarellas de argilla, e poftas de duas em duas. Habita os mares da Noruega, forvendo, e ao depois lançando a agua, fegundo nada, ou mergulha. 
(AR 


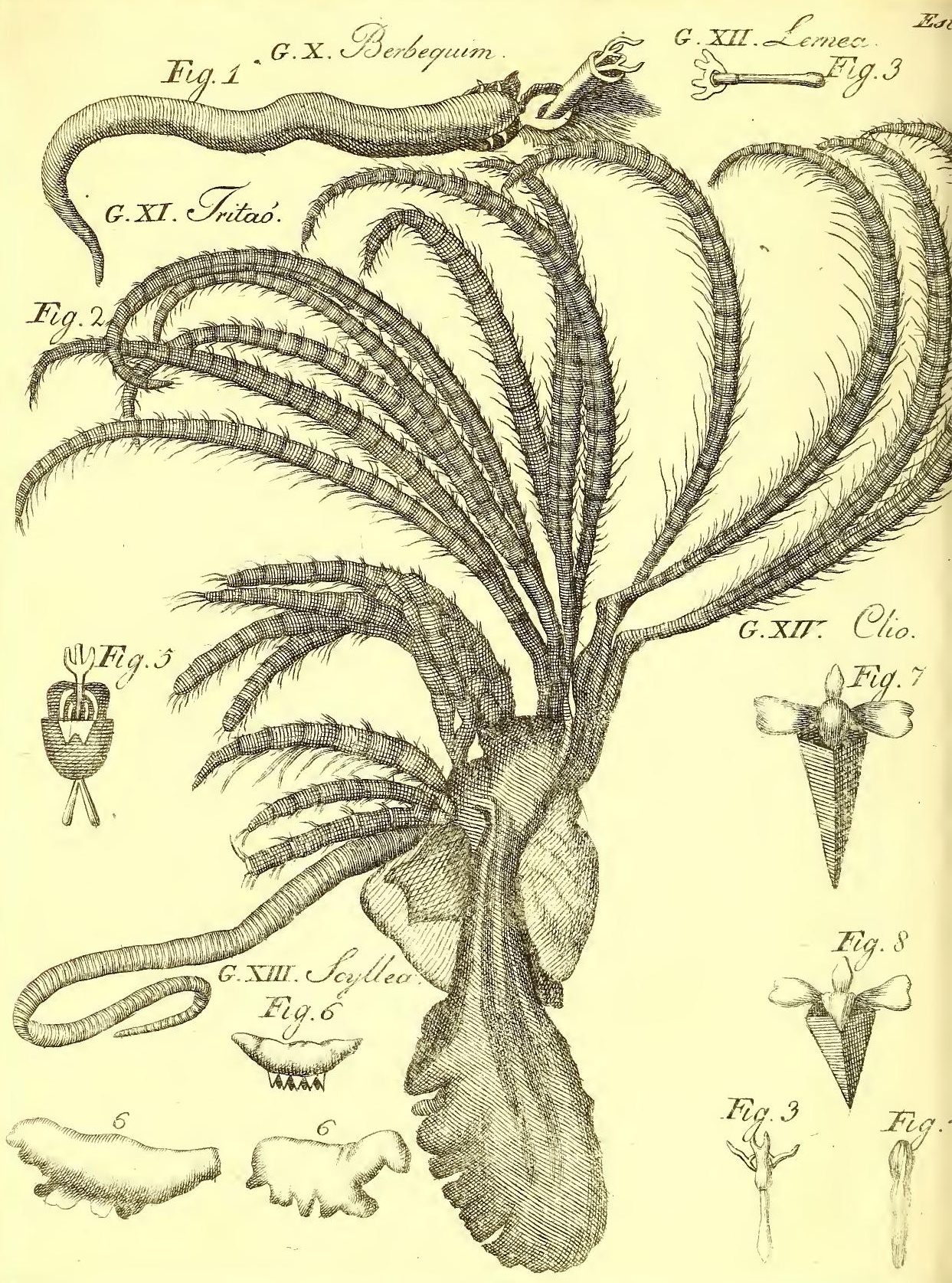




\section{G E N E R O X.}

B E R в E Q I M. (Terebella.)

\section{Caracter Generico.}

O corpo filiforme, a boca adiante. O prepucio faz avançar? buma glandula pedunculada, e tubulofa. Os tenteadores.

$\therefore$ muitos ao redor da boca, e capillares.

\section{Berbequim apincellado. Ef.VII. Fig. I.}

\section{$T$}

Em o nome da femelhança com os pinceis, de qưe fe fervem os Pintores. Do meio do pello fahe a cabeça do pequeno infecto, foftida em hum pefcoço comprido, e com. duas pontas ramofas. A boca he redonda, armada de pequenos dentes, como os Ouriços do mar, com os quaes moe o feu fuftento. Os pellos faố finiffmos, macios, como feda, efformaó huma poupa, de cujo meio tahem o pefcoço, e cabeça ao depois, como le acaba de notar. O feu corpo tem a fórma de hum Verme : he muito comprido, e acaba pontudo em huma das extremidades, no que imita bem a ponta do pincel ; vê-fe por baixo a pequeua cabeça do noffo Pincel, recolhida para traz, como no Caramujo : caminha pelo foccorro de cinco pequenos pés, poftos de cada lado na extremidade do feu corpo, em a origem do feixe de pellos, e apertados huns com os outros. 


\section{GE N E R O XI.}

$$
\text { T R I } \mathbf{T} \text { A ó. }
$$

\section{Caracter Generico.}

O corpo allongato. A boca com lingua enrofcada, ou efpirat.

Tem doze tenteadores divididos em duas partes, com

Seis de cada lado, as de traz cbeliferos, ou

com tenazes.

\section{TrITAố da praia. Eft. VII. Fig. 2.}

$\mathrm{H}$

E hum animal muito fingular. A fua grandeza anda pela ametade da Ciba ordinaria : o corpo rara vez tem mais de tres pollegadas de comprido. A fua figura he oval, e alguma coufa comprimida; a bafe faz a maior largura do oval, donde fe diminue infenfivelmente até a cabeça; efta he allonga: da, e arredondada, naó comprimida, e tem em parte huma membrana efpeffa, e couriacea, que une todos os tenteadores nas fuas bafes, como faz a membrana dos pés dos patos, e aves aquaticas. Dous dos tenteadores faó fimples, allongados, e de figura conica, e os outros doze faó cheliformes nas extremidades. Encontraö-fe nas praias de Italia. 


\section{G E N E R O XII.}

$$
\text { L } E \begin{array}{lllll} 
& R & N & E & A_{0}
\end{array}
$$

\section{Caracter Generico.}

O corpo se pega pelos tenteadores: fua fórma oblonga, roligha: tem dutus oveiros, que fervem de caudas: dous, ou tres tenteadores em feigă de bragos.

\section{Lernea do Barbo. Eft. VII. Fig. 3 .}

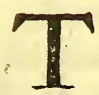

Em quatro tenteadores, dos çuaes dous faó formados nos topos em meia Lua. Efta efpecie he pequena; pois fó tem meia pollegada de comprimento, e a grofitura de huma palha miuda. O corpo he redondo, de hum branco pardo denegrido, luzente na fuperficie, e alguma confa tranfparente. $\mathrm{Na}$ bafe fahe de huma efpecie de bainha, que he de cor branca, e fe affemelha a huma pelle algurn tanto groffa. $\mathrm{Na}$ outra extremidade do corpo fe achao tres tuberculos obtufos, dos quaes hum he mais groffo, que os outros. Situa-fe a boca na parte anterior da cabeça, e perto temt duas achegas molles, e carnudas, e de huma, e outra parte da boca hum prolongamento molle, terminado $\mathrm{cm}$ meia lua, no topo. Encontra-fe nos lados do Barbo, Sargo, e Salmonete dos noflos tanques, e rios em muito grande abundancia. 


\section{$46 \quad H E L M I T H O L O G I A$}

\section{Lernea do Salmaö. Eft. VII. Fig. 4.}

O corpo he oval, o arcabouço em fórma de coraçaó, e os dous braços lineares muito juntos, e conchegados hum ao outro.

\section{Lernea do Bacalbáo. Ef.VII. Fig. 5.}

O corpo alıado, ou em lua, e o arcabouço acoroçoado. Encontra-fe no Bacalháo, e na Pefcada nos mares boreaes. Toma o nome d'Afellina deftes peixes, que Varraó, Ovidio, e muitos outros Authores Latinos fimplesmente chamaó Afelli. Ray, Villoubgy, Schoneveldt, Johnfton, e todos os outros Efcriptores modernos fe fervem do mefmo termo. 


\section{G E N E R O XIII. \\ S C C I L L L E A.}

Caracter Generico.

O corpo pegador, comprimido, acanalado pelo compri. mento das coftas. A boca be bum buraco jem denstes, pofta na extremidade: com tres pares de tenteadores, ou bracos por baixo.

\section{SCILEa do golfo. Ef. VII. Fig. 5.}

Corpo allongado, comprimido, e molle. A boca $\mathrm{f}$ tuada na extremidade menor com huma abertura diminuta. As coftas longitudinalmente acanaladas, com huma cova chanfrada, pela qual fe prende as Algas, ou Sargaços, quando def́cança. A parte pofterior obtufa, e mais larga. Por baixo fe encontraó tres pares de braços apartados huns dos outros; o primeiro, debaixo da boca, menor, e mais redondo; o fegundo, debaixo do meio corpo, folhofo, alongado, dobrado, algum tanto obtufo, femeado de mamillos por dentro; o terceiro, proximo das partes pofteriores, femelhantes ao primeiro. Mora nas Algas fluctuantes. 


\section{G E N E R O XIV.}

$$
\text { C I. I } 0 \text {. }
$$

\section{Carafer Generico.}

O corpo nadador, e a fórma he allongada: tems dilas azas membranofas, buma em frente da outra.

I. Cr.Io de cauda. Eft.VII. Fig. 6.

T affim dizer. Habita no Oceano. Efte animalejo em huma pofiçaó perpendicular, e fervindo-fe dos feus dous tenteadores, em feiçaó de azas, fe affemelha a hum paffaro, que fahe de hum funil.

\section{Curo Pyramidal. Ef. VII. Fig. 7•}

Huma bainha triangular, em pyramide, a boca obliquamente truncada. Mora no Oceano. Efte animal fe diftingine do precedente em ter a fua bainha mais curta. 


\title{
G E N E R O XV.
}

\author{
C I B A.
}

\section{Caracter Generico.}

Tem por dentro oito braços jemeados de cotyledöes (fóra dous tenteadores longos, e pedunculados pela maior parte). $A$ boca de fubftancia cornea efla fituada na extremidade entre os dous braços. O corpo carnido recebe o peito em buma bainba. Encontra-Se bum tubo na base do peito.

$\mathrm{E}$

Ncontra-fe efte animal nas coftas do Mediterraneo, e Oceano de hum, e dous pés de comprimento, e alguns até de dous covados. Tem à cabeça armada de duas trombas, e oito braços tendinofos, guarnecidos em todo o fen comprimento de huma multidaó innumeravel de chupadores. Com eftes braços, e aquellas trombas apanha as Pelamitas, Anchovas, Lagoftas, e Conchas, de que fenutre. Tambem lhe fervem de cordas, teancoras, com que fe agarra, para refiftir aos movimentos das ondas, abaladas pelas tempeftades. Eftes chupadores, da figura da cupola de huma Lande, faó armados de huma multidaó de ganchos pequenos. As Cibas os applicaó aos corpos, que apanła ó, ou áquelles, á que fe agarraó. Todas eftas forças reunidas fao mui poderofas. No centro do braço tem of feu bico, què tem a mefma fórma, e figura, como o do Papagaio: As ferreas fe diftinguem por duas efpecies de tetas. Ellas fe ajuntaố em coito, da mefma fórte que os Polvos, e Chocos, ou Lulas, abraçaó-fe. mutuamente, e poémวos feus owors algas Algas, sem feiçaó de hum cacho de uvas.s No momento, em que os poem, faổ brancos. Os machos thes pafáo por cima , e os fecundaó com hum liquor negro. Eilles engroffaó. Em LangueG doc 
doe os chamaó Cachos de Cibas. Quando fe abrem, fe vem nelles as Cibas vivas. Os machos faó maridos conftantes. Acompanhaó-nas por toda a parte. Eftando ellas em perigo, elles fe expoem ao mefmo em fua defera, com intrepidez, e com rifco de perder a vida. As femeas tímidas fogem, logo que vem os machos feridos. $\mathrm{O}$ grito da $\mathrm{Ciba}$, quando a tiraó d'agua, fe affemelha ao grunhido de hum porco. Quando os feus machos faó perfeguidos por Lobos marinos, e outros peixes carniceiros, efcapaó por traça. Lançaó o feu liquor negro na dofe algumas vezes de huma oitava. A agua em hum inftante fe efcurece, fica negra, como a tinta, e com a ajuda defta nuvem efpefia, o animal efcapa á perfeguiçaó do inimigo. Efta tinta, on liquor negro foi nomeado por M. Cat Etbiope animal. Seu depofiro he $\mathrm{cm}$ huma glandula. Em feu eftado de liquido fe affemetha perfeitamente a Choroide do homem. Tem capacidade de tingir pannos de huma cor indelevel. Quando fecca, fe julgaria fer o producto do liquor negro das Cibas, precipitado pelo efpirito do vinho. Efte Ethiope animal eftá em os negros, como tambem em a Ciba em maior abundancia, aodepois da morte, do que em vida. $\mathrm{A} \mathrm{Ciba}$ he hum alimento muto duro, e de má digeftaó, a naó fer amollecida em agua falgada, com cal viva, e cinzas. Julgaó fer os feus ovos aperitivos. $\mathbf{O}$ offo das Cibas he taó leve, ao depois da morte do animal, que nada nos fluidos. Efta armaçaó offea no principio he hum pouco molle, e fe endurece ao depois. Algumas veżes a chamar efcuma, outras, bifcoito do mar. A fua organifaçaó he maravilhofa. Obferva-fe huma multidaб de columnas verticaes, que da lamina fuperior paffaó para a inferior. Muitas vezes fervem de regalo aos Canarios. Os Ourives fórmaó com efte pó excellentes moldes para obras pequenas, como culheres, garfos, \&c A tinta da Ciba póde fervir para a efcrita, e para a prenfa. Os Romanos ufavaó della para efcrever. Pertende-fe, que 


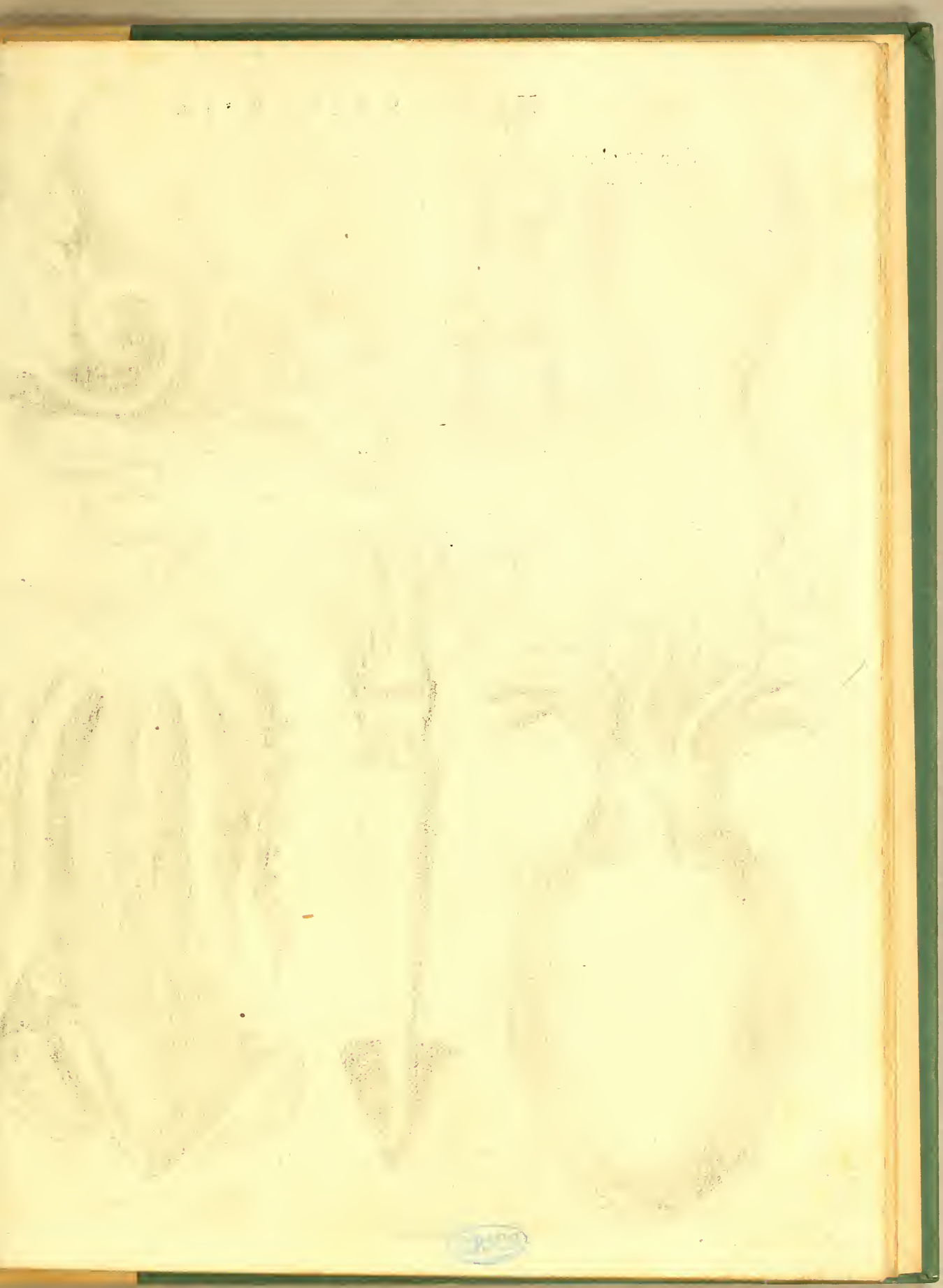




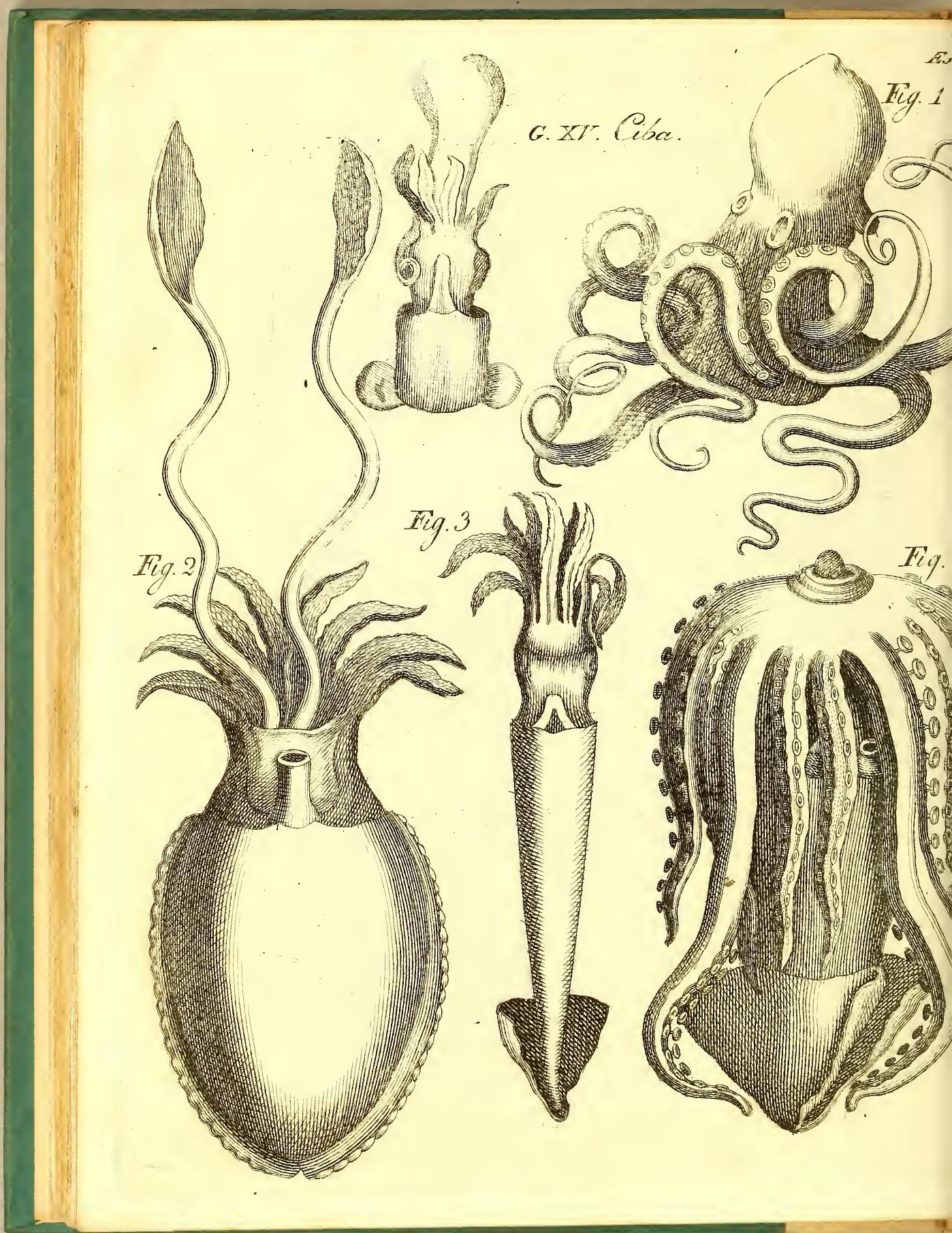


mifturada com arroz, entre na compofiçaó do Nanquirn dos Chins.

\section{Ciba de oito pés. Eft. VIII. Fig. I.}

O corpo naó tem cauda, nem tenteadores com pedurculos. Quando fe comem, as devèm fazer vermelhas com 0 feu proprio liquor, fervendo-o com Salitre, Bartholino adverte, que quando fe abre, lança huma taó grande luz, que de noite, eftando as vélas apagadas, a cafa parece incendiada. Encontra-fe no Mediterranco.

\section{CiBA das Boticas. Ef. VIII. Fig. 2。}

Corpo fem cauda, mas com huma borda, e dous tenteadores. O feu offo, he o que fe vende nas Boticas, e a tinta, com que fe occulta, ferve para efcrever. He verdade o que diffe Plinio no IX.' Lib. co 29. que os Congros the comem os braços, e que lhes tornao a nafcer, como acontece á cauda dos Lagartos. Mora no Oceano, e ferve de preza ás Azevias.

\section{Ciв media. Ef. VIII. Fig.3.}

O corpo deprimido com huma cauda dividida em duas. Ella fe affemelha á precedente, e tem demais em os lados huma membrana, a qual fómente he pegada aos lados pela ametade, e naó he longitudinal. Mora nos mares. 


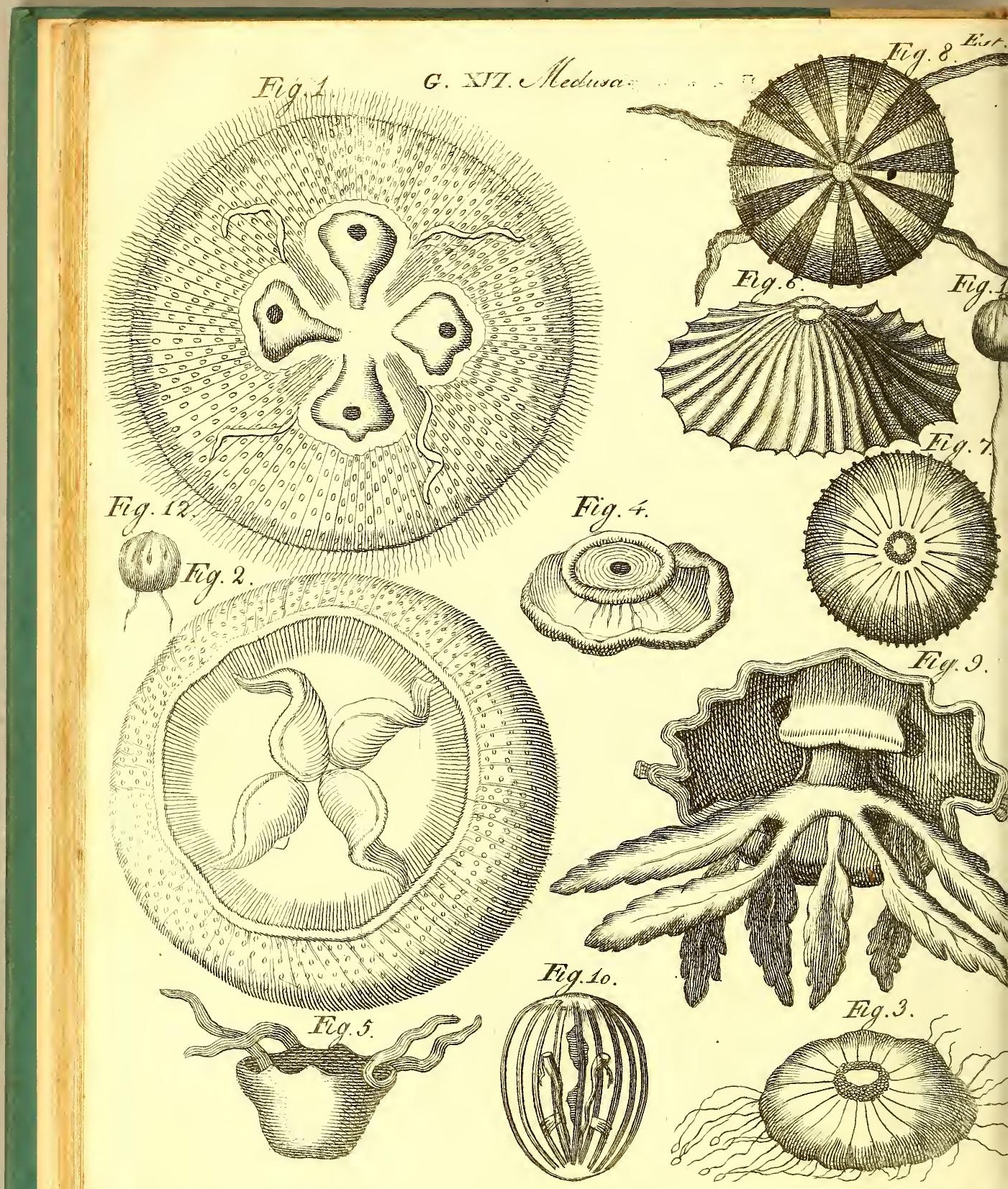




\section{G E N E R O XVI.}

$M E D$ U S A.

Caracter Generico.

O corpo be de huma fubftancia vifcora, arredondado por cima, e cbatado por baiwo. A boca occupa o centro debaixo.

\section{Medusa encruzada. E $\Omega$. IX. Fig. I.}

A Medufa, que tem o orbiculo affignalado de huma cruz, he huma bellifima efpecie. He huma maffa de huma linda gelea tranfparente, e fem cor ; mas, pondo-fe ao Sol, apparece algumas vezes, como incendiada, e outras vezes reprefenta todas as cores do arco iris. Habita os mares da Europa, e algumas vezes fe encontra nas praias de Suffez.

Linne the deo o nome de encruzada, porque no meio de feu corpo, fe achaó quatro partes, que parecem fazer huma cruz. Eftas partes faó de hum branco, como leite, trazendo no feu meio huma pinta negra, affaz grarde. $\mathbf{O}$ anjmal he todo diaphano, affemelhando fe na cor a agua do mar, fendo vifto a travez. Mas com a ajuda de hum microfcopio fe diftinguem huma quantidade de pequenos pontos, e linhas tiradas do centro a circumferencia. A borda he guarnecida de fibras miudas, que tem hum movimento contínuo, quando o animal nada. Ainda que feja diaphano, he provido de hum fem número de mufculos, por cujo meio fe move, e fe dobra para todos os lados.

II. 


\section{Mepusa de orelhas. Eft. IX. Fig. 2.}

Vendo-fe fluctuar entre as ondas, fe reputaria fer huma maffa de gelea informe, e inanimada. A fua cor he efbranquiçada, , com hum matiz pardo azulado, e a fua figura orbicular, convexa na parte luperior, chata na inferior, e guarnecida de cadilhos, on franjas de flamentos finos, e alguma coufa engrovinhados em torno da borda, como cabellos brancos. Na fuperficie debaixo, tem quatro caridades junto ao centro, e cada huma deftas de figura abobadada, e rodeada de huma linha opaca, que fórmaó vinte e quatro pontos parallelos. Do centro da mefma parte inferior fahem quatro achegas, ou appendices ganchofos, os quaes todos tem huma ordem de filamentos pelludos, pela borda exterior; e na fuperficie fuperior fe encontra huma apparencia de vafos delicados de cor pallida.

Muitas vezes fe vê efta efpecie na fuperficie do mar, ou fluctuante, on tambem pegada pelos rochedos nas noffas coftas ; e quando o Sol a fere por cima, faz hum lindiffimo effeito pelo feu brilhante.

Alguns Authores a denominaó Ortiga do mar; por fer hum dos animaes, que fendo tocados, caufáó na maó huma titillaçaó defagradavel.

Sufpeito que a Medufa encruzada, e a de orelhas fá o mefmo animal ; por ter cuidadofamente examinado o feu individuo vivo, e achar que as duas fuperficies correfponderiaó exactamente á defcripçaó de Linne, quando chegaffem á fua ultima grandeza. Póde fer que elle naó tiveffe elta occafiaó, ou que fó viffe a encruzada no feu eftado diminutivo. 


\section{Medusa cabelluda. Ef.. IX. Fig. 3.}

Efte animal he muito fingular, por ter a apparencia de huma malfa esbranquiçada, e ametade tranfparente, e por fe deftruir taó facilmente pelo toque, como o fazem as geleas, que enfeitaó as noflas mezas. A fua forma he arredondada, levantada em convexo no meio ; onde ella confequentemente tem a fua maior grofura, e fe diminue infenfivelmente para os lados; por baixo he igual, e fobre efta parte fe topa hum circulo efcabrofo, ou ouriçado, do centro do qual fahem oito pares de raios que vem para a circumferencia; e do centro fe levantaó baftantes appendices engrovinhados, que faó algumas vezes avermelhados ; porém mais ordinariamente esbranquiçados, como tambem baftantes fios miudos. A borda, ou circumferencia do corpo he regularmente dividida em oito porçóes, das quaes cada huma he fem reborde, ou beiço, de fórte, que em toda a bordadura tem dezaleis finus. Efta efpecie fe encortra em grande abundancia frctuando á flor d'agna, junto á Ilha de Sheppy no Condado de Kent, e em outros lugares nas mefmas cóftas. Deftroe-fe huma grande quantidade, que as ondas arrojaó as praias, donde naó he poffivel retirarem-fe ; e no alto mar hum grande numero de peixes fe levantaó á fuperficie pas ra os apanharem. Muitos Authores chamaó a eftes animaes bofes do mar.

\section{Medusa barrete. E $/$. IX. Fig. 4.}

He orbicular, e ao feu difco fobrefahe huma cabeça; a borda tem oito buracos; e por baixo delle he abobadada, e pillofa. Mora no mar. 
V. Medusa bolfa. Eß.IX. Fig. 5.

He meia oval, com quatro tenteadores na borda. Achafe no Mediterraneo.

\section{Medúsa de véo. Ef.IX. Fig. 6.}

Oval com eftrias concentricas, a borda peftanuda, coberta de hum véo membranofo por cima.

\section{Medusa parda. Ef. IX. Fig. 7 .}

Tem hum circulo pardo no meio, com 16 raios da mefma cor, que fahem do centro para a circumferencia : efta ultima tem huma ordem de tuberculos ovais, e de garras ganchofas, poftos alternativamente, com quatro tenteadores retalhados, de maior comprimento que o corpo.

\section{Medusa tuberculada. E $f$. IX. Fig.8.}

Efta tem quinze liftras tiradas, e unidas no centro em hum pequeno ponto, com huns pequenos tuberculos ovaes, fituados ao redor da borda, e tem quatro tenteadores fimples, os quaes fe allongaô, e eftendem fóra do corpo. 
IX. Medusa ondeada. Ef.IX. Fig.9.

As fuas bordas faó ondeadas, com garras nas partes falientes, quatro orificios por baixo, entre os quaes fe levanta huma haftea dividida $\mathrm{cm}$ oito tenteadores grandes, e retalhados. Borlaffe na fua hiftoria de Cornwalba faz mençaó deftas tres efpecies acima defcriptas.

\section{Medusa oval. E/f.IX. Fig. Io.}

Saó abundantes no mez de Março; e ainda que fejaŏ diaphanas, fe the conhecem nove lados rodeados de fibras delgadiffimas, que fempre fe achaó em movimento. Dentro do corpo fe daó algumas particulas menos tranfparentes, e entre eftas de duas efpecies de pequenos tubos, dos quaes hum vifivelmente tem huma abertura na extremidade fuperior.

\section{Medusa globofa. Efl. IX. Fig. II.}

Efta he a Beroe de Brown com dous tenteadores, muito eftendidos, e compridos. Tamber os tem encolhidos.

Todas as Medufas tem qualidades phofphoricas, faó animaes gregarios, que vivem em companhia nos climas quentes, e fobre tudo, no Oceano Indico : em as noites bonançofas, quando eftaó em repoufo, apparecem em baixo da agua, femelhantes a hum rochedo branco, ajuntando-fe tantas, que occupaó hum efpaço de muitas varas de extenfă.

Eftes animalejos nadaó em grandes cardumes para procurarem o feu mantimento, fazendo hum movimento con$\mathrm{H}$ 


\section{8}

H E L M I N T HOLOG I A

tínuo de feus tenteadores, com os quaes apanhaó a fua preza, e a trazem á boca.- Ellas variaó de grandeza, tendo a maior, pela maior parte, oito pollegadas de diametro. $\mathbf{O}$ numero dos tenteadores he igualmente differente; humas tendo unicamente dous, outras quatro, feis, e algumas oito, número efte, a que rara vez excedem. Apanhaố a fua preza com tanta força, que nenhuma lhes efcapa. Os infectos, os pequenos peixes, \& $c_{\text {. }}$, lhes fervem de paito.

\section{G E N E R O XVI. \\ Estrellas do mar. (Aflerias.)}

Carâter Generico.

Ocospo chato, coberto de buna coftra meio costriacea, ous= rifada, cam tenteadores. A boca no centro com cinco valvulas.

\section{D}

Ivide-fe efte genero em tres familias, 1 . inteiras, 2. eftrelladas, 3. e radiofas.

Entre as Eftrellas do mar; humas tem quatro radios, outras finco, outras muito mais. Humas faó vermiformes, outras cabelludas Dón-fe algumas, cujos braços faó guarnecidos de puas, on picos, dos quaes fe deve ter receio. Encontraofe eftes animalejos á borda dos mares, fobre areia : a abertura, que fe lhe obferva no centro, he a boca do animal. Vem-fe nella cinco dentes offeos, dos quaes fe ferve, para apanhar, e quebrar as conchas, de que fe fuftenta. A efpecie de tampo, que tem na parte oppofta da boca, he o anus. Cada raio da Eftrella he guarnecido de huma extraordinaria quantidade de pernas. Huma Eftrella chega a ter 1520. Eitas pernas fe affemelhaó aos cornos do Caramujo, 



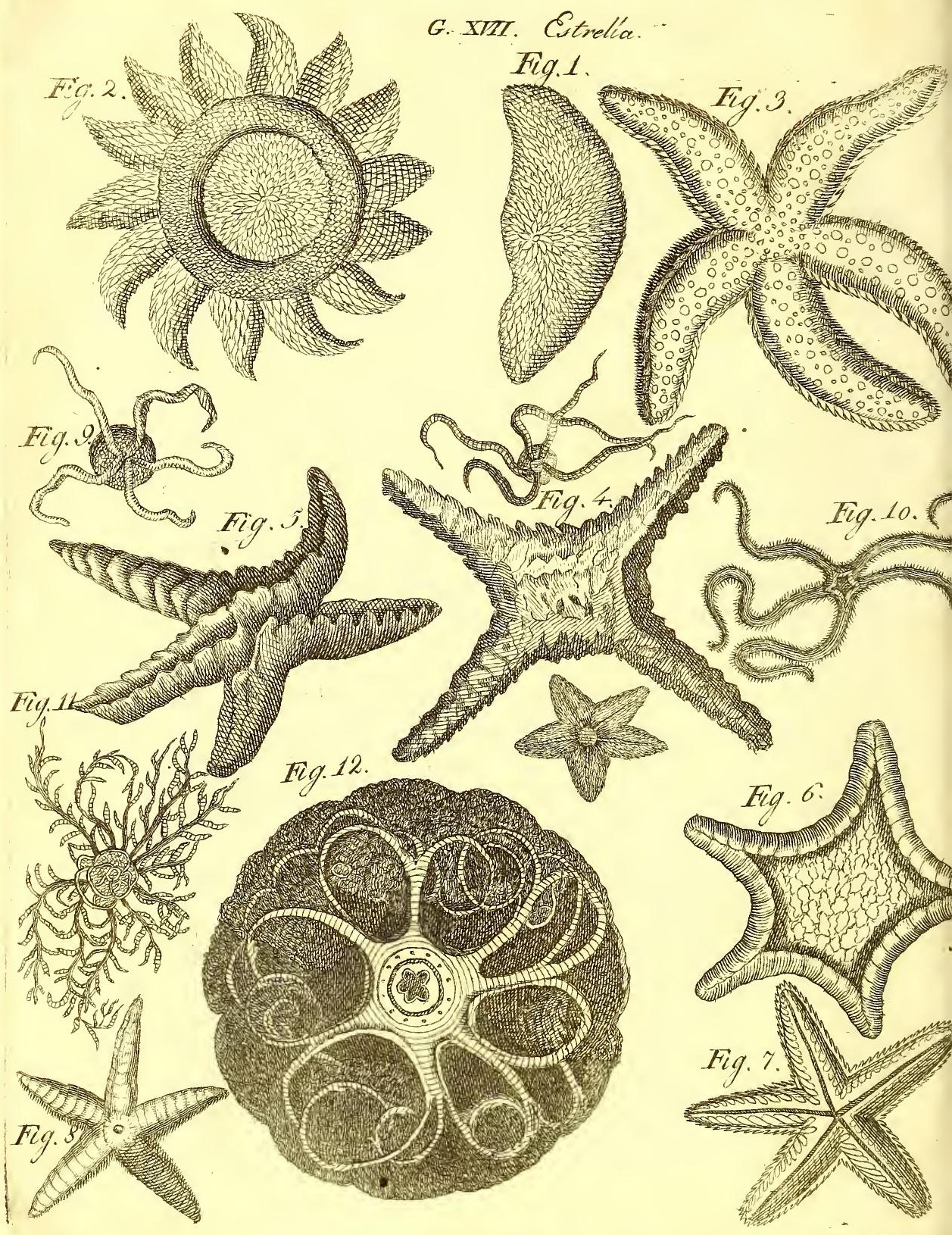


on Lefma. Na fua origem interior faó pequenas bólas redondas, cheias de hum liquor aquofo. Por contracçaó do animal, efte liquor the entra nas pernas, e as faz fahir, e inchar, como os cornos do Caramujo. Ainda que munida de hum taó grande número de pés, a Eftrella fó caminha vagarofamente. Eftes pés pódem-fe colher pelos rochedos, e plantas. Servem-lhe como de cordas, para fe agarrar, e refiftir ao movimento das ondas, e das tempeftades. Seus raios faó frageis : o menor choque os quebra, e os leva, mas, como os Camarobes, tornaó a crefcer. As Eftrellas caminhaố indiferentemente para todas as partes, para diante, para traz, para os lados, nadando nas aguas por hum movimento obliquo, e por undulaçaó de feus raios, os quaes, fendo cortados, fazendo ellas algum esforço, cahem pelo feu proprio pezo no fundo das aguas. As Eftrellas do mar, cur jos raios naó faó providos de pernas, caminhaó, agarrando-fe com os raios para o lado, para que querem ir, e dobrando os raios oppoftos, para poderem avançar.

\section{Estrella Lua. Efo.X. Fig. x。}

Iriteira, femiorbicular, em fórma de meia lua. Mora na India. Linne deo o nome de Lua a efte animal pela maior femelhança, que tem com efte aftro, do que as outras defte genero, que faó mais femelhantes ás Eftrellas.

\section{Estrella empolada, ou de mamillos. Ef.X. Fig. 2.}

Radiofa de Braços, armada de pontas, ou puas em molhos por todos os lados. Habita o Oceano Europeo, e Afiatico. 
60 HEI I N H OLOGI A

III. Estrelda purpurea. Eft. X. Fig. 3. Tem cinco raios unidos,
de huma bella cor de purpura.

IV. Estrella reticulada. Ef.X. Fig. 4.

He eftrellada com raios reticulados, e pont'agudos.

V. Estrella nodoJa. Efl.X. Fig. 5 .

Eftrellada, com raios converos, elevados longitudinalmente, e munidos de pontas. Encontra-fe no Oceano Indico.

\section{Estrella aranbolla. Ef.X. Fig. 6.}

Eftrellada, o difco ouriçado, de tenteadores enruga-: dos, a borda articulada, e pontuada com diverfidade. Mota no Mediterraneo:

\section{Estrella equefre. Ef.X. Fig. 7 •}

Eftrellada : o difco emmalhado em rede, e penetrado de pontos. Tem cinco tuberculos; a borda quafi articulada, e por baixo fó tem huma ordem de tenteadores. Mora no Mediterraneo. Tem hum difco por baixo, o que naó tem a precedente. 


\section{Esthella lifa. Eff.X. Fig. 8.}

Eftrellada, com raios femicylindricos, obtufamente de oito quinas, e lifos. Mora nos mares Mediterraneos, e Indicos. Os raios faó cobertos de tuberculos, ou verrigas ça fádas. Os intervallos deftes nos lados fá femeados de pontos cavados. Por baixo tem raios guarnecidos de verrugas, em fórma de quinconce com huma abertura longitudinal.

\section{Estrella Cauda colubrina. (Oqupos) Eft. X Fig. 9.}

Radiofa, de cinco raios fimples: a Eftrella orbiculada, de cinco lobos, ou ancos. Mora no Oceano.

\section{Estriella pefamuda. Eft.X. Fig. Iо.}

Radiofa, e atelhada, ou coberta, como telhas, e os raios dos dous lados peftanudos. Mora nos mares do Sul, e das Indias.

\section{Estrolla em pente. Ef. X. Fig. I I.}

Radiofa com raios dobrados, os fuperiores, como barbatanas, as inferiores em feiçaó de fios. Mora no Oceano Indico. 
XII. Estreliá cabega de Medusa. Eft.X. Fig 12.

Tem cinco raios, fahindo de hum corpo angulofo, e dividindo-fe cada raio $\mathrm{em}$ ramos fem número, que fe vaú diminuindo, on adelgaçando á proporçaó, que fe affaftaó da fua bafe. Habita em toda a parte no Oceano, partictlarmente nos braços do mar. Alguns a appellidaó Efrrella do mar de Magalbầes, e em Corbeille. A ponta dos raios nefta efpecie fe fubdivide com huma delicadeza quafi, que fenaó póde conceber; e o animal inteiramente eftendido fórma hum circulo, que tem quafi tres pés de diametro: os raios quebrados defte peixe formaó os entroques foffeis, ou cavadiços.

Mergulhando-fe a Eftrella do mar em agua-ardente, ou efpirito de vinho, e que fe applainem os raios, e fe eftendaó na operaçaó , he facil extrahir com tenazes o eftomago inteiro do animal pela boca. 


\section{POR TंU G UE E. \\ G E N E R O XVIm. \\ O U R I G O. (Ecbinus.)}

Caracter Generico. O corpo quafi redondo, coberto de buma cofira offea, pela
maior parte ourigada, com espinbos movediggos.

D

Ivide-fe efte genero $\mathrm{cm}$ duas familias huma regular, e a outra irregular. A $\mathbf{r}^{\mathrm{a}}$ tem o anus vertical: a $20^{a}$ a aber: tura do anus por baixo, e tamberm a boca.

A fua eftructura he das mais maravilhofas. Guarnecido de picos efcamofos maiores, ou menores, e duros, os quaes faó as pernas movediças, que fervem no movimento progreflivo do animal. Alguns tem até duas mil pernas. Caminhaó para todos os lados. Entre eftas pernas fe vem doze para quinze mil tenteadores, cujo ufo parece fer deftinado a reconhecer o terreno. Servem de cordas, que as aju. daó a fegurarem-fe nas tempeftades. Defde que fe vem, a eftes animaes mergulhar no mar, ancorar-1e, fe eftá feguro de haver algum temporal. As fuas cabeças eftaó poftas na abertura. Saơ armadas de pequenos dentes. Em Marlelha fe vendem os Ouriços na praça, como as Oftras. Só fe pódem abrir, tendo as máos calçadas de luvas : comem-fe, eftando cheios de ovos, como os das gallinhas. He precifó eftar-fe affeito a efte alimento, que no principio parece defagradavel. Morrendo o animal, cahem as pontas, ou bicos, que the formaó o Ouriço, e ficaó as fuas apophyfes defcobertas, e hum fem número de pequenos buracos, que cobrem a concha repartidamente.

Tem-fe difputado muito entre os Phyficos, fe os Ouricos do mar pertencem propriamente aos animaes coftraceos,

ous 
ou aos teftaceos; e a queftaó fe refolve facilmente, dizendo, que naó pertencem a qualquer delles. Seus caracteres, a eftrutura de feus corpos, e ainda a fórma, o ufo, e o fim de fuas partes cxteriores commummente comprehendidas, debaixo do termo de concha os faz differentes abfolutamente de todo o animal; e como taes faó animaes a parte, e que fe difpoem em confequencia.

Klein, que fenaó fatisfez da divifaó deftes corpos, as dividio em muitos generos; mas todos elles fe difpoem aflaz cómmodamente em duas familias das do fyftema de Linne.

\section{Ouriço comeftivel. Eft. XI. Fig. 1.}

Hemifphericamente globofo com dez avenidas, os efpaços intermediarios cobertos de verrugas gaftas, e de efpinhos fortes, pontudos de meia pollegada, de cor violete. Mora no Ozeano da Europa, e da India. Apanha-fe nas redes: poufa nos buracos dos rochedos, na altura dos fluxos, e refluxos. Os habitantes pobres de muitas cóftas os comem, o que fe pratica tambem por Eftrangeiros de diftinçaó. Os Romanos faziaó delles hum dos feus guizados favorccidos. A fituaçaó natural defte animal he ter a parte larga, ou deprimida, que fe chama a bafe, para o fundo da aguia. Na abertura, on centro defta, fe acha a boca, que tem cinco dentes agudos, fixos nas extremidades de cinco offos pequenos, da qual a lingua occupa o centro. A fua bafe he huma caruncula de forma arredondada, e toda carnuda. Da parte pofterior da boca começa hum conducto inteltinal, levado por muitos contornos para dentro da concha, a qual fe fuftem por huma multidaó de fibras delgadas. Termina-fe finalmente a abertura no alto da concha, por onde o animal depoem os feus excretos. Efta abertura, que diffemos da eftructura geral do animalejo, póde tambem fer- 


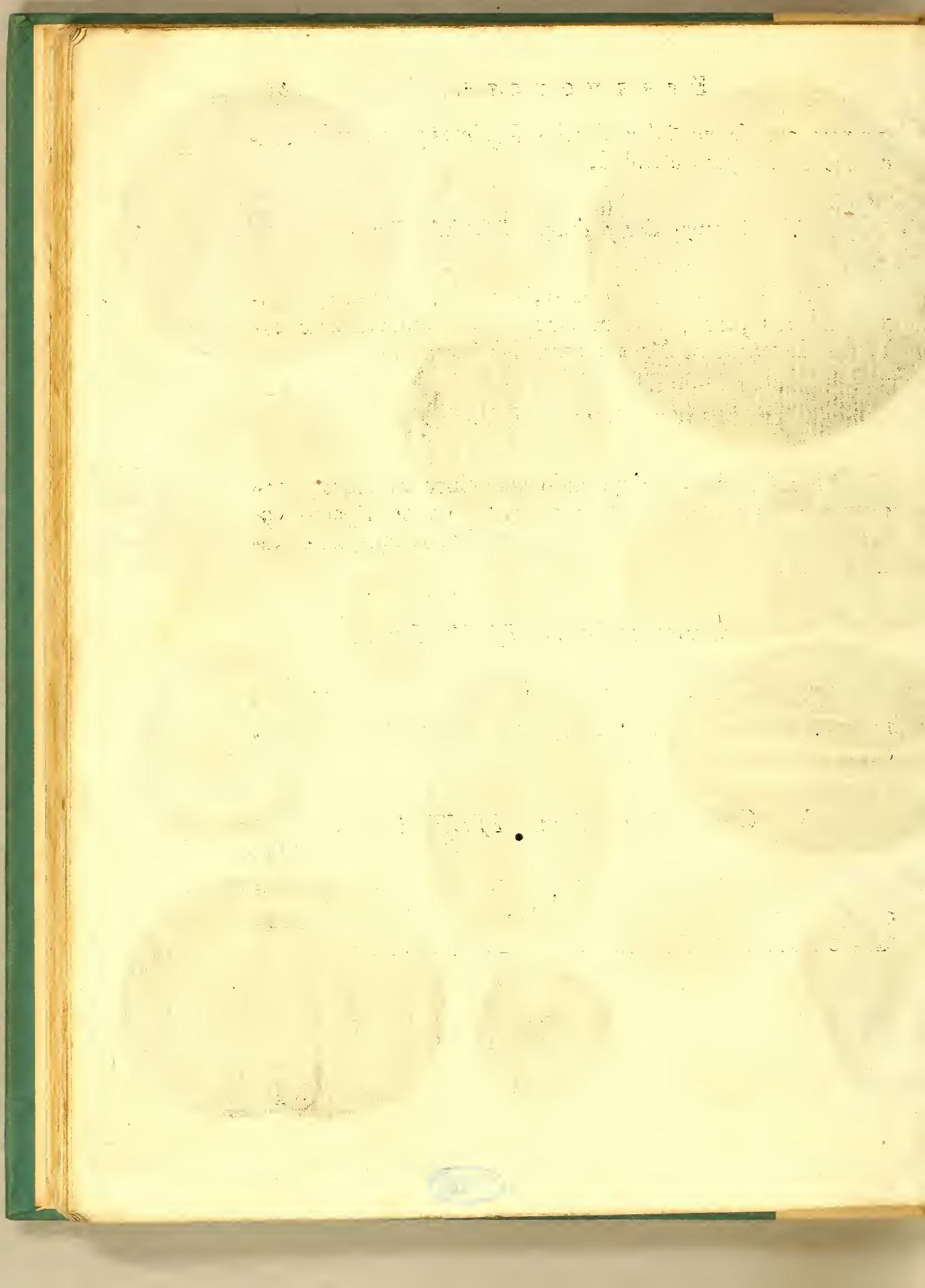




$$
P O R \text { I U U E } Z \text { A. }
$$

vir para a deferipçaó das efpecies feguintes; pois todas concordaó neftes particularidades.

\section{Ouriço das pedras. Efi. XI. Fig. 2.}

Hemípherico, e aplainado, com dez avenidas, aproximadas aos pares, com os efpaços longitudinalmente co. bertos de verrugas. Mora no mar Mediterraneo.

III. Ouriço diadema. Eff.XI. Fig. 3 .

Hemifpherico, e deprimido com cinco avenidas, Jongitudinalmente munidas de verrugas : com os efpaços cobertos de pontas á maneira de lanças. Encontra-fe no Oceano Indico:

\section{Oviço turbante. Ef. XI. Fig. 4.}

Hemifphericamente deprimido com cinco avenidas lineares, dobradas com os efpaços alternativamente divididos em dous. Mora no Oceano.

\section{Ouriço de mamillos. Ef.XI. Fig. 5 .}

Hemifphericamente oval, e dez avenidas; com os efpaços efpinhofos, guarnecidos de verrugas, as mais eftreitas, e encolhidas. Domicilia-fe no Oceano do Sul. 


\section{Ouriģo do mar negro. ES. XI. Fig.6.}

Hemifphericamente oval, e alguma coufa deprimido, rendo efpinhos troncados, mui breves, e obtufos, os da borda amaffetädos, erdeprimidos. Encontrafe na India.

\section{Ouriço encbada. E $l . X I$. Fig. 7 .}

Em fórma de ovo, levantado em corcova, e com cinco avenidas, deprimidas. A fua morada he $\mathrm{cm}$ todo o Oceano.

VIII. Ouriço lagoa. E $2 . X I$. Fig. 8.

Em fórma de ovo , corcovado, com cinco avenidas deprimidas. A fua morada he no Oceano da India.

\section{Ouriço Rofa. Ef. XI. Fig. 9.}

Alguma coufa aplainado, em fórma de ovo, com cinco avenidas ovaes; a fuperficie apontuada. Mora no Oceano da Afia.

\section{Ourrço rede. Efl. XI. Fig. yo.}

Alguma coufa aplainado, oval, e lifo, com cinco avenidas ovaes : a fuperficie enxaquetada, ou emmalhada, como huma rede. Mora no Oceano d'America. 


$$
\text { P OR T U G U E Z A }
$$

XI. Ouriço bolo. Efl. XI. Fig. Ir.

Chato, e orbiculado com cinco avenidas, repartidas em duas: $\mathrm{O}$ anus na borda. Mora no Cceano meridional.

\section{Ourı̨̧o circular. Efl. XI. Fig. I2.}

Aplainado, avifinhando-fe ao circulo, com cinco avenidas ovaes ; o anus affaftado. Mora nos mares da India.

Os animaes, que pertencem a efte genero, faó diverfamente coloridos, fendo a fua cor geral, entre o violete, o pardo avermelhado, e a purpura carregada. Os e!pinhos tem tambem as mefmas tintas, mas as fuas pontas faó pela maior parte mais pallidas, e tambem tirantes fobre o branco.

Em o gabinete do excellente naturalifta, o defunto Doutor Solander, fe via hum animal deftes de hum azul violete magnifico, apanhado nos mares do Sul, que aqui chamarei : Ouriço violete, ou diadema coifa do Doutor Solander. 

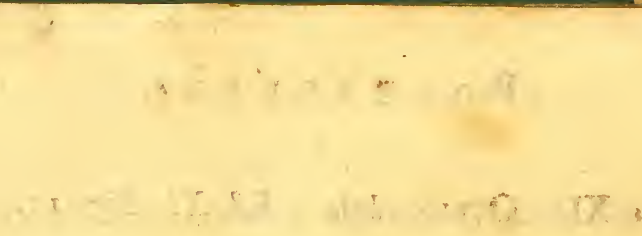

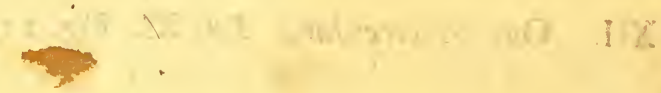

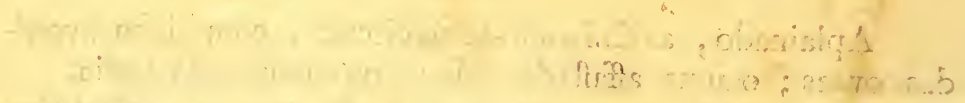

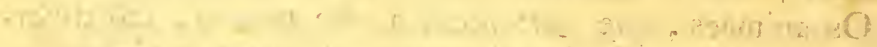
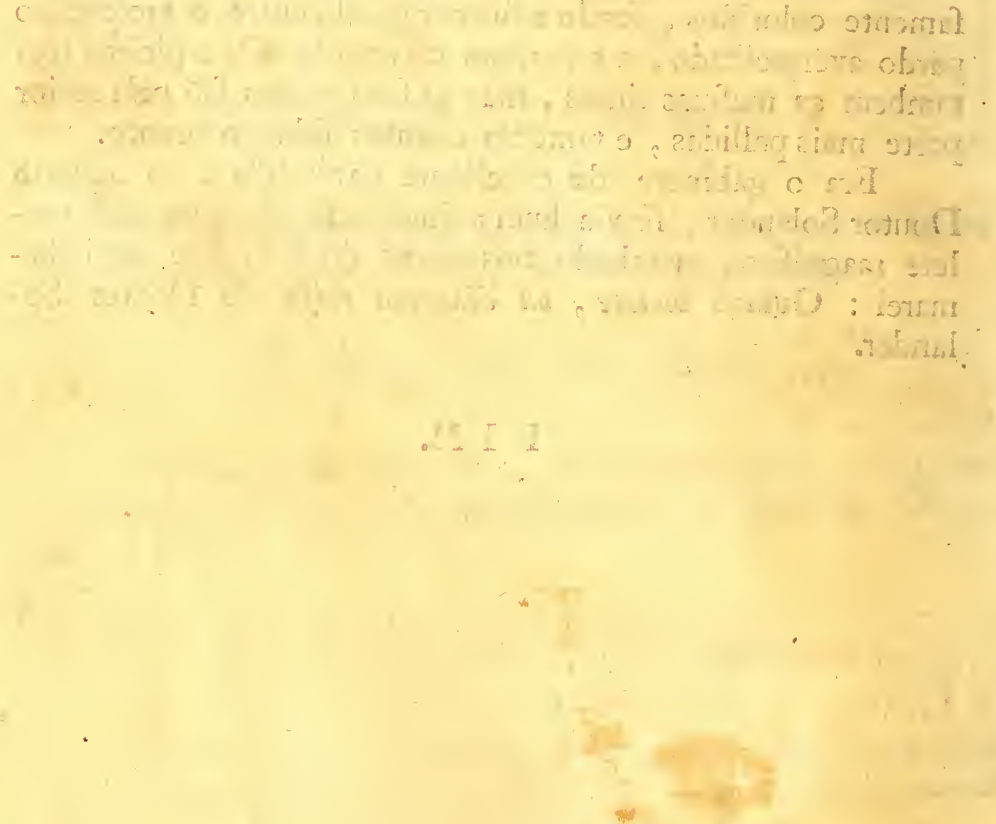


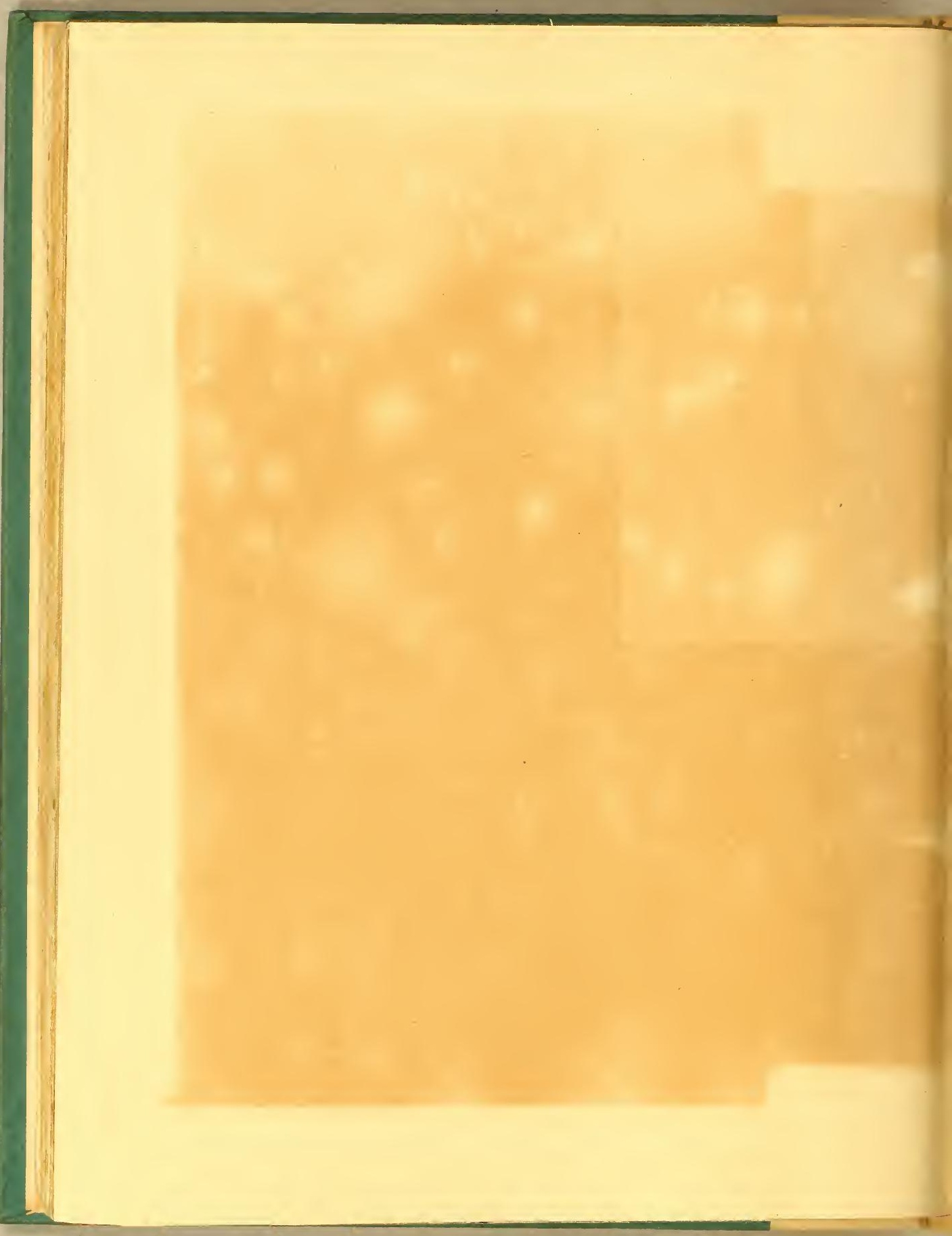


D 799
$B 241 \mathrm{~h}$

$+2$ 


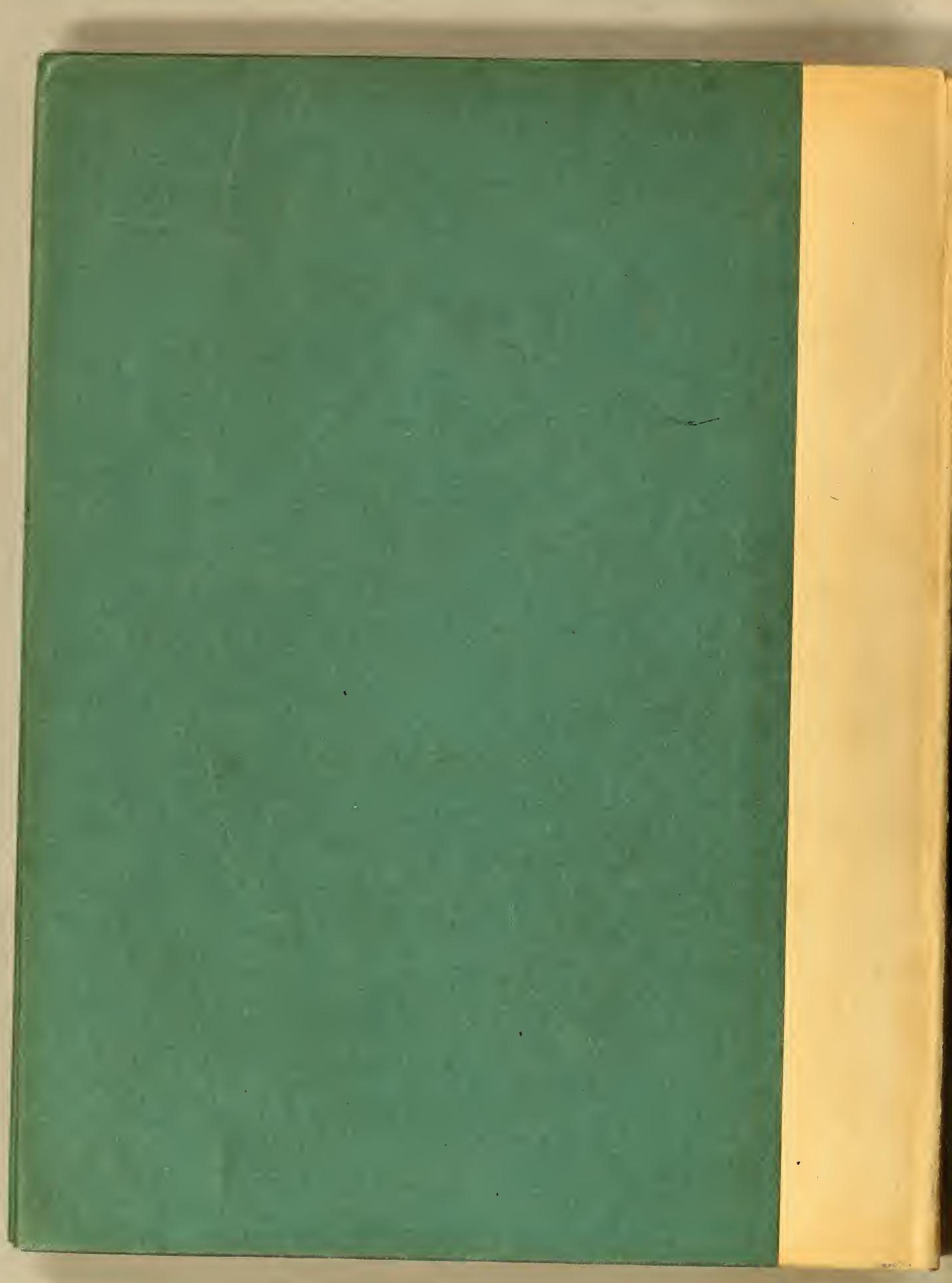

